OPEN ACCESS

Edited by:

David Naor,

Hebrew University of Jerusalem, Israel

Reviewed by:

Toru Hiraga,

Matsumoto Dental University, Japan Carmela Ricciardelli,

University of Adelaide, Australia

*Correspondence:

Suniti Misra and Shibnath Ghatak, Department of Regenerative Medicine and Cell Biology, Medical University of

South Carolina, 173 Ashley Avenue,

Charleston, SC 29425, USA misra@musc.edu; ghatak@musc.edu

Specialty section:

This article was submitted to Inflammation, a section of the journal Frontiers in Immunology

Received: 07 February 2015 Accepted: 13 April 2015

Published: 06 May 2015

Citation:

Misra S, Hascall VC, Markwald RR and Ghatak S (2015) Interactions between hyaluronan and its receptors

(CD44, RHAMM) regulate the activities of inflammation and cancer.

Front. Immunol. 6:201.

doi: 10.3389/fimmu.2015.00201

\section{Interactions between hyaluronan and its receptors (CD44, RHAMM) regulate the activities of inflammation and cancer}

\author{
Suniti Misra ${ }^{1 *}$, Vincent C. Hascall ${ }^{2}$, Roger R. Markwald ${ }^{1}$ and Shibnath Ghatak ${ }^{1 *}$ \\ ${ }^{1}$ Department of Regenerative Medicine and Cell Biology, Medical University of South Carolina, Charleston, SC, \\ USA, ${ }^{2}$ Department of Biomedical Engineering, Cleveland Clinic, Cleveland, Ohio, OH, USA
}

The glycosaminoglycan hyaluronan $(\mathrm{HA})$, a major component of extracellular matrices, and cell surface receptors of HA have been proposed to have pivotal roles in cell proliferation, migration, and invasion, which are necessary for inflammation and cancer progression. CD44 and receptor for HA-mediated motility (RHAMM) are the two main HA-receptors whose biological functions in human and murine inflammations and tumor cells have been investigated comprehensively. HA was initially considered to be only an inert component of connective tissues, but is now known as a "dynamic" molecule with a constant turnover in many tissues through rapid metabolism that involves HA molecules of various sizes: high molecular weight HA (HMW HA), low molecular weight $\mathrm{HA}$, and oligosaccharides. The intracellular signaling pathways initiated by HA interactions with CD44 and RHAMM that lead to inflammatory and tumorigenic responses are complex. Interestingly, these molecules have dual functions in inflammations and tumorigenesis. For example, the presence of CD44 is involved in initiation of arthritis, while the absence of CD44 by genetic deletion in an arthritis mouse model increases rather than decreases disease severity. Similar dual functions of CD44 exist in initiation and progression of cancer. RHAMM overexpression is most commonly linked to cancer progression, whereas loss of RHAMM is associated with malignant peripheral nerve sheath tumor growth. HA may similarly perform dual functions. An abundance of HMW HA can promote malignant cell proliferation and development of cancer, whereas antagonists to HA-CD44 signaling inhibit tumor cell growth in vitro and in vivo by interfering with HMW HA-CD44 interaction. This review describes the roles of $\mathrm{HA}$ interactions with $\mathrm{CD} 44$ and $\mathrm{RHAMM}$ in inflammatory responses and tumor development/progression, and how therapeutic strategies that block these key inflammatory/tumorigenic processes may be developed in rodent and human diseases.

Keywords: hyaluronan, CD44, RHAMM, inflammation, cancer

Abbreviations: CD44v, variant isoform of CD44; GAG, glycosaminoglycan; HA, hyaluronic; HAS, hyaluronan synthase; HMW HA, high molecular weight HA; HYAL, hyaluronidase; LMW HA, low molecular weight HA; oHAs, HA oligosachharides; PEG, polyethylene glycol; PEI, polyethyleneimine; PTX, paclitaxel; RHAMM, receptor of HA-mediated motility; RTK, receptor tyrosine kinase; shRNA, short hairpin RNA; siRNA, short interfering RNA; Tf, transferrin. 


\section{Introduction}

The interplay between cells and with components in the extracellular matrix (ECM) of the microenvironment is tightly regulated during normal physiological processes of tissues and organs (13). During inflammation and tumorigenesis, cellular communications are dramatically lost with subsequent extensive remodeling of cellular and molecular composition of the tumor microenvironment, which supports inflammation, cancer cell proliferation and migration/motility, invasion, and metastasis. Carcinogenesis is characterized by an inflammatory response where biologically active ECM fragments regulate tissue injury/remodeling. Notably, the biosynthesis and degradation of the glycosaminoglycan (GAG) hyaluronan (HA), a major component in ECMs, is associated with the rapid matrix remodeling that occurs during embryonic morphogenesis, inflammation, and tumorigenesis $(4-7)$.

Hyaluronan is a non-sulfated, linear GAG composed of repeating disaccharides of $(\beta, 1-4)$-glucuronic acid (GlcUA) and $(\beta$, $1-3)-N$-acetyl glucosamine (GlcNAc) $(\mathrm{MW} \sim 400 \mathrm{Da})$ (Figure 1). Native HA in most tissues has a high molecular mass of 1-10 million Da with extended molecular lengths of 2-20 $\mu \mathrm{m}(8-11)$. HA has crucial roles in structuring tissue architecture, in cell motility, in cell adhesion, and in proliferation processes $(12,13)$. These cellular events are mediated mainly through two major signal-transducing cell surface HA-receptors, CD44 (14-19) and the receptor for HA-mediated motility (RHAMM) designated as CD168 (20) (Figure 2), which was first described by Turley (21, 22) as a soluble HA-binding protein released by sub-confluent migrating cells (23). HA is the principal ligand of CD44 (16), and alternative splicing and differential glycosylation produce multiple structural and functional versions of CD44 that are responsible for proinflammatory activities, including cell-cell and cell-matrix interactions $(6,24-26)$. The CD44 ectodomain includes an aminoterminal domain that contains a HA-binding "link module" motif related to those in the HA-binding proteoglycans and the link proteins (27). Like CD44, RHAMM is alternatively spliced, and variant forms of RHAMM are found both on cell surfaces and inside the cells $(28,29)$. However, they do not have the link module domain. They have a BX7B motif that also can bind to HA, where " $B$ " represents arginine or lysine, and " $X$ " represents any nonacidic amino acid (30). Studies indicate that CD44-mediated cell

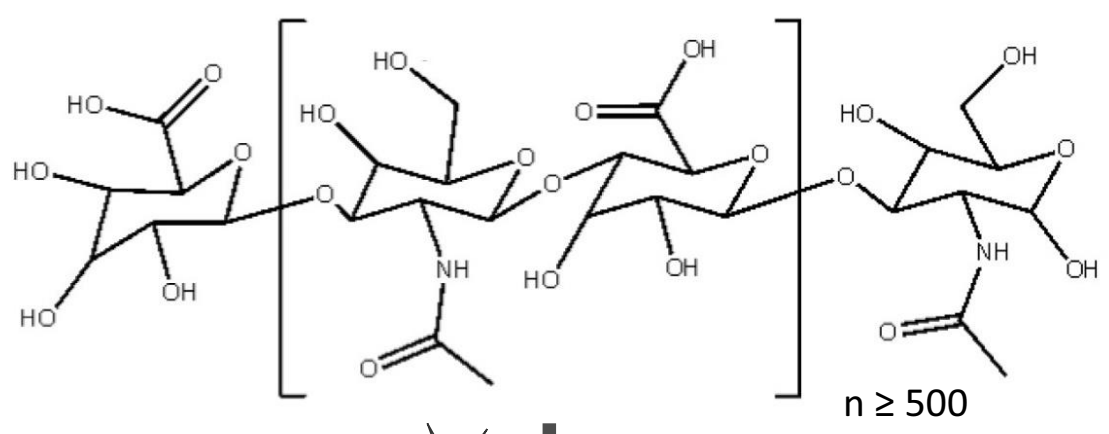

HYAL1-2, Free radicals

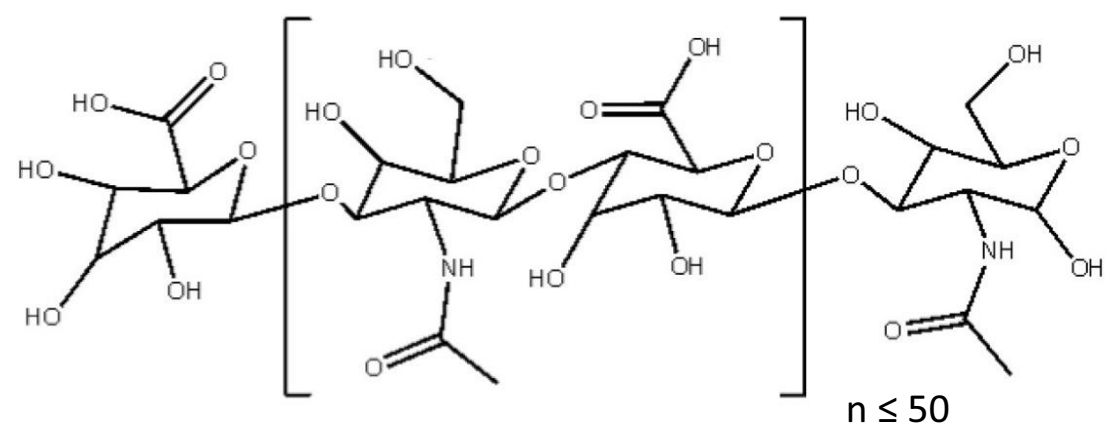

Can bind to CD44 and are Biologically active

FIGURE 1 | Native polymeric HA and degraded HA fragments. High molecular weight (HMW $\geq 500$ disaccharide units; [ $\beta-1,4-G l c \cup A-\beta-1$, 3-GlcNAc]n synthesized in the normal homeostatic condition is degraded by free radicals and hyaluronidases (HYAL1-2) during inflammation/tumorigenesis when tissue injury occurs. These fragments are $\leq 50$ disaccharide units. As a result, the fragments of different molecular weights have different biological functions. For example, intermediate fragments $(30-500 \mathrm{kDa})$ can stimulate cell proliferation while smaller fragments $<50 \mathrm{kDa}$ promote cell migration. HA oligosaccharides down to three disaccharides can still bind to CD44. 

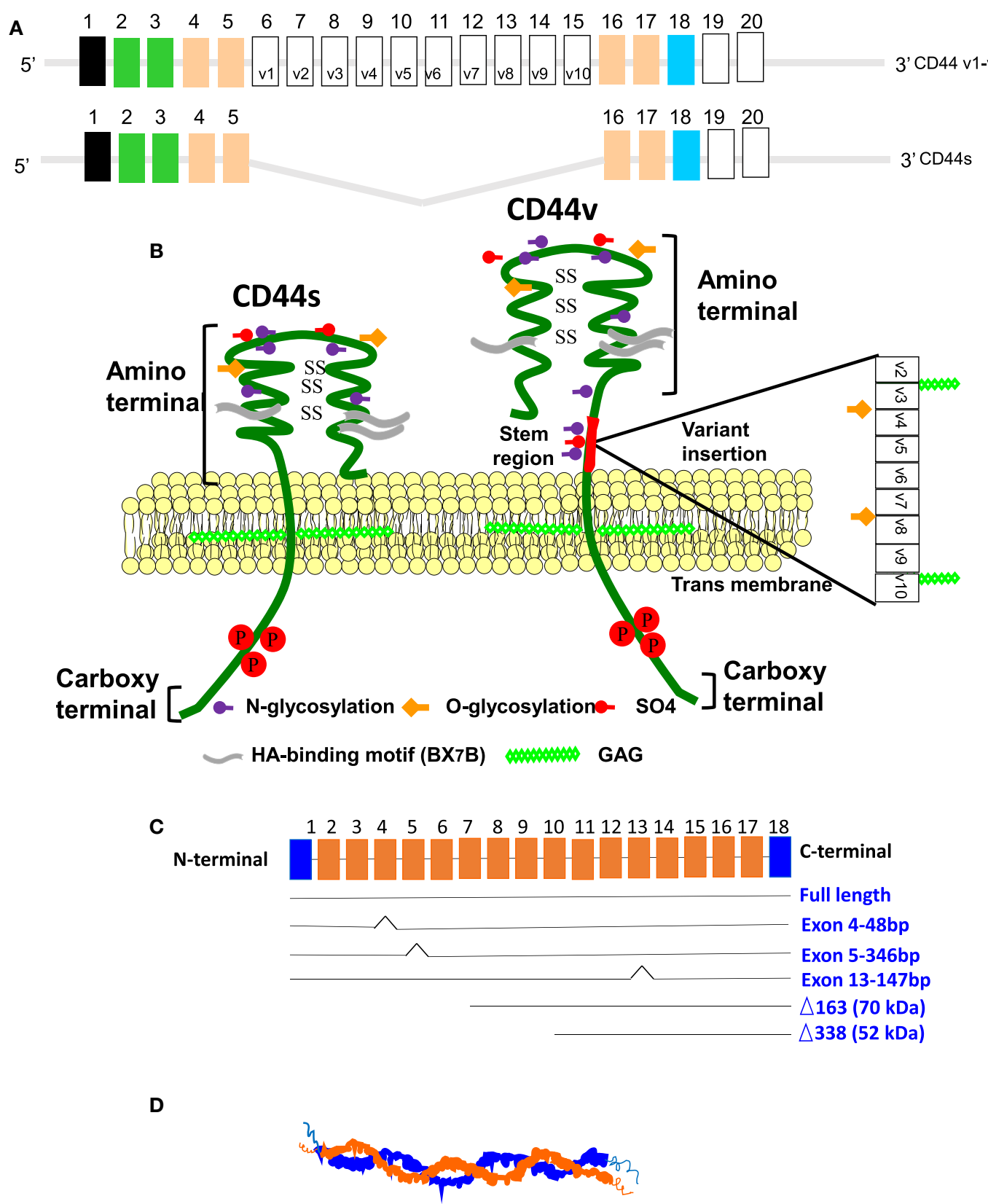

FIGURE 2 | (A) Mouse CD44 and RHAMM gene/protein structures in mice. Model structure of alternative splicing in CD44. CD44 pre-mRNA is encoded by 20 exons in mouse and 19 exons in human being. The common standard CD44s (hematopoietic) form contains no extra exons, and the protein has a serine motif encoded in exon 5 that can initiate synthesis of a chondroitin sulfate or dermatan sulfate chain. Alternative splicing of CD44 predominantly involves variable insertion of 10 extra exons with combinations of exons 6-15 and spliced in v1-v10 into the stem region, of which v3 encodes a substitution site for a heparan sulfate chain. Variable numbers of the $v$ exons can be spliced in epithelial cells, endothelial cells, and inflammatory monocytes and also are upregulated commonly on neoplastic transformation depending on the tissue. (B) Model structure of alternatively spliced CD44 proteins. The CD44 protein is composed of an extracellular $\mathrm{N}$-terminal domain, a stem region in the extracellular domain close to the transmembrane region, where the variant exon products (red/violet circles) are inserted, the transmembrane region, and the carboxyl terminal cytoplasmic tail. There are multiple sites for $N$-glycosylation (purple circles) and O-glycosylation (orange circles), and a sulfation domain. The $\mathrm{N}$-terminal portion contains highly conserved disulfide bonds as well as 2 BX7B motifs, both of which are essential for HA binding. CD44 is subjected to extensive glycosylation, sulfation, and attachment of GAGs that contribute to regulation of the $\mathrm{HA}$-binding activity. The $\mathrm{C}$-terminal cytoplasmic tail contains several phosphorylation sites that regulate the interaction of CD44 with the cytoskeletal linker proteins, as well as with SRC kinases. (C) RHAMM exon structure. The full-length protein ( $85 \mathrm{kDa}$ in human beings) is largely associated with microtubule formation during the cell cycle progression. Three isoforms are generated by alternative splicing of exon 4, 5, or 13. Loss of exon 4 disrupts association with microtubules and results in the appearance of RHAMM in the cell nucleus. $\mathrm{N}$-terminal truncations that may be generated by a posttranslational mechanism are constitutively present in some aggressive breast cancer cell lines and tumors. These accumulate in the nucleus and on the cell surface. (D) The secondary structure of RHAMM. RHAMM can self-associate to form random coiled coils (132). 
migration during inflammation, wound healing, and tumorigenesis can require surface expression of RHAMM. However, the mechanism of cooperativity between RHAMM and CD44 is not clearly understood. In this review, we discuss the nature of such interactions and the important therapeutics that can target CD44 and RHAMM in inflammation and cancer.

\section{HA in Inflammation and Cancer}

\section{Biology of HA}

Hyaluronan is a ubiquitous component of tissue ECM found in a native homeostatic form within hydrated tissues such as the vitreous of the eye, articular cartilage, synovial fluid, lymphatics, and skin. HA is present in interstitial collagenous matrices and increases viscosity and hydration. This impedes fluid flow through matrices by forming a barrier (31). HA is found in pericellular matrices attached to the HA-synthesizing enzymes or its receptors and is also present in intracellular degradation compartments (6, 7, 32-37). HA differs from the other GAGs: it is not synthesized on a core protein as a proteoglycan in the Golgi. Instead it is synthesized by single transmembrane HA synthases (HAS1, HAS2, or HAS3) at the inner face of the plasma membrane. The cytoplasmic active HAS sites alternately add the UDP-GlcUA and UDPGlcNAc substrates to the reducing, UDP-anchored elongating HA molecule that is being systematically extruded through the plasma membrane into the ECM to form the very long, unmodified HA macromolecules without any sulfated or epimerized uronic acid residues $(23,38)$. The HAS isozymes (HAS1, HAS2, HAS3) differ from each other in their catalytic activities as well as in the sizes of the synthesized HA. HAS1 and HAS2 polymerize long high molecular weight (HMW) chains while HAS3 produces predominantly shorter low molecular weight (LMW) chains $(<300 \mathrm{kDa})$, and HAS3 appears to be more active than HAS1 and HAS2 (38-40).

While its structure is simple, HA is an extraordinarily versatile macromolecule. Its biophysical properties provide HA with functions that influence the hydration and biomechanical properties of different tissues, especially those of the vitreous humor in the eye, the synovial joint fluid, and the dermis (41). In addition, HA also interacts with extracellular macromolecules and HA-binding proteoglycans, including versican and aggrecan, which are important in the assembly of ECMs and of pericellular glycocalyces that can act as protective cellular barriers and are essential for the assembly and structure of many tissues (41-44). For example, increased levels of aggrecan immobilized on HA in collagen networks resists the variable compressive loads essential for the physical properties of cartilages (45).

Successful morphogenesis also relies on physical properties of HA as well as on signaling events triggered by HA-CD44 and/or HA-RHAMM interactions. During embryogenesis, HA promotes proliferation and migration of undifferentiated stem cells to sites of organ development (26). Importantly, Has2 null mice fail to synthesize HA during cardiac cushion development, and the endothelial cushion cells do not undergo mesenchymal transformation (EMT) and cannot form the underlying connective tissue, which leads to midgestational death $(5,46)$. Recent studies also indicate that the matricellular protein periostin binding to the integrins activates the HA synthesis and HA-mediated Akt/PKB and focal adhesion kinase (FAK)/Erk signaling pathways, which by feedback loop, further sustains Has2 expression for cell survival, and importantly, differentiation of embryonic cardiac mitral valve cells (47) (Figure 3B).

Hyaluronan turnover is important for the maintenance of tissue homeostasis, and $\sim 30 \%$ of HA is replaced by newly formed HA per $24 \mathrm{~h}$ (48). Removal of HA occurs by endocytic uptake within the tissue, especially in lymph nodes and liver. Importantly, the presence of reactive oxygen species (ROS) enhances HA turnover (49-51). Internalization and degradation of HA is triggered by its binding to CD44 (52) and/or lymphatic vessel endothelial receptor-1 (LYVE-1), which is expressed in lymphatic endothelium (53). HA is degraded into monosaccharides by three enzymatic reactions. Hyaluronidases (HYALs) degrade HA to oligosaccharides, which are then digested into GlcUA and GlcNAc by $\beta$-D-glucuronidase and $\beta$ - $N$-acetyl-D-hexosaminidase $(54,55)$. In human beings, there are six HYAL genes, HYAL14, HYAL-P1, and sperm-specific PH-20 (54, 56-58). These enzymes can have different catalytic profiles. For example; HYAL1 degrades HA into oligosaccharides while HYAL2 degrades HMW HA into fragments of intermediate size $(\sim 20 \mathrm{kDa})$. PH-20 is anchored to the sperm acrosomal membrane through a glycosylphosphatidylinositol (GPI) moiety, which promotes penetration of spermatozoa through the HA matrix in cumulus-oocyte complexes for fertilization $(54,59)$. In recent years, recombinant human PH20 devoid of the GPI anchor has been prepared (60) and tested for increasing drug penetration in skin and pancreatic tumors in an animal model (61).

As mentioned earlier, under physiological conditions, HA exists as a HMW polymer $>10^{6} \mathrm{Da}$ providing structural frameworks for cells. Such HMW HA functions as an extracellular molecule transmitting signals and regulates a variety of cell behaviors, including cell adhesion, motility, and growth $(6,8-11,37)$. HA chains up to $20 \mathrm{MDa}$ are involved in ovulation, embryogenesis, wound repair, and tissue regeneration (62). In malignant cells, HA polysaccharides $\left(>10^{6} \mathrm{Da}\right)$ are abundant. HA levels can be increased around tumor cells themselves or within the tumor stroma to maintain normal cellular functions of the tumor cells. Because of the close association of high HA levels with malignancy in many tumor types (37) considerable experimental evidence implicates $\mathrm{HA}$ and its main receptor CD44 variants in tumor progression both in cell and animal models (6, 25, 37, 63-69). HMW HA induce activation of tyrosine kinase in endothelial cells and Ras-transformed fibroblasts at lower level $(70,71)$ compared to fragmented HA (71). However, the ability of the naked mole rat to synthesize high molecular mass HA (five times larger than human HA) is correlated to the cancer resistance and longevity of naked mole rat (72), but this animal is a rare species. A recent study established that reducing HAS levels using antisense techniques suppresses tumor growth, but showed that extremely high HA levels also inhibit tumor growth, possibly by suppressing cell-cell interactions, or ligand access to cell surface receptors (73). Remarkably, following tissue injury, HA and its degraded fragments $<5 \times 10^{5} \mathrm{Da}$ size accumulate. Such smaller size HA was shown to be crucial for the production of cytokine and chemokine for differentiation/activation of the macrophage (74-76). HA of 
A

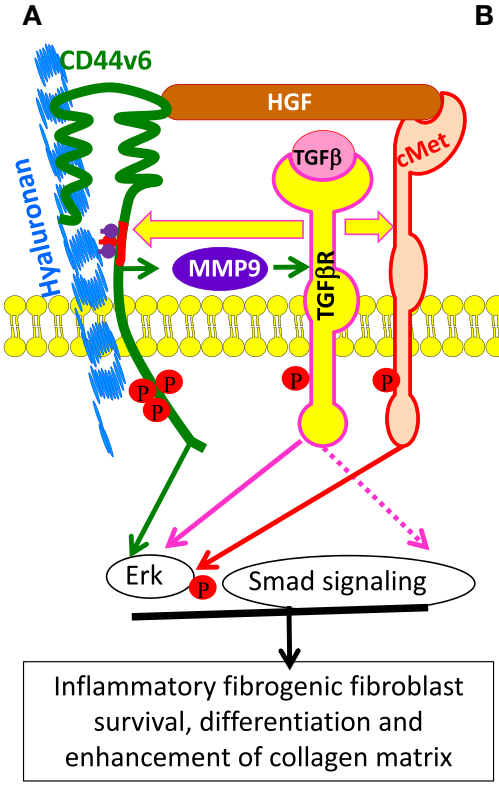

B

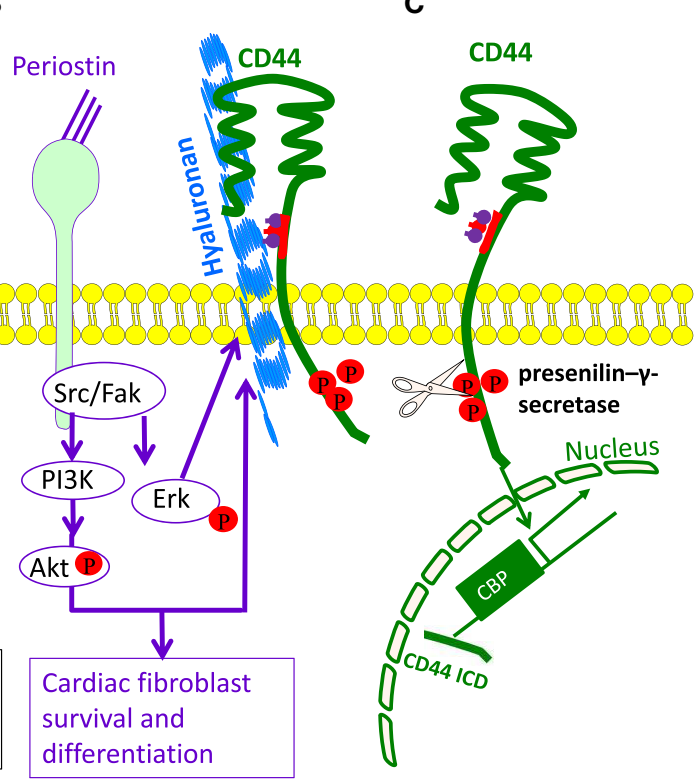

FIGURE 3 | The involvement of HA and CD44 in cell survival and differentiation. (A) Model for the involvement of CD44v6 and Met due to autocrine TGF $\beta 1$ signaling in lung fibrogenic fibroblasts. The repetitive lung injury in pulmonary fibrosis results in overexpression of TGF $\beta 1$ and

TGF $\beta 1$-induced autocrine signaling that induces a sustained expression of CD44v6 and its co-receptor c-Met. This activates fibrogenic lung fibroblasts with subsequent increased collagen matrix synthesis. Therefore, TGF $\beta 1$-induced CD44v6 and Met can have a crucial role for the sustained fibrogenic activation of lung fibroblasts. The CD44-phosphorylated ERM complex initiates activation of transforming growth factor- $\beta$ receptor 1 and 2 (TGFBRI and II) and the downstream SMAD signaling complex, which contribute to fibrosis. (B) Model for involvement of periostin in
HA-CD44-mediated cell survival and differentiation. Matricellular protein [periostin (PN)] binding to $\beta 1$ or $\beta 3$-integrin activates FAK, which activates downstream MAPK/Erk and PI3K/Akt to regulate cardiac valve cell growth, survival, differentiation into fibroblasts, and matrix organization (maturation). PN binding to $\beta 3$-integrin also activates Has2 mRNA expression, Has2 phosphorylation, and HA synthesis. The interaction of HA with CD44, may, in turn, amplify the downstream effects of PN on heart valve cushion cell differentiation/maturation processes. (C) Cleavage of the extracellular domain is accompanied by the cleavage of the intracellular domain (ICD) by the presenilin- $\gamma$-secretase complex. The CD44 ICD acts together with CBP or p300 as a transcription factor and promotes CD44 transcription and extracellular matrix production. size $<5 \times 10^{5} \mathrm{Da}(\sim 250,000 \mathrm{Da})$ induce inflammatory genes with renal tubular epithelial cells (77), T-24 carcinoma cells (78), and eosinophils (79). Similarly, HA fragments of size 8-16 disaccharides induce angiogenesis in a chick corneal assay, whereas the native HA molecules do not (80-82). Similarly, smaller HA fragments in the $6-20 \mathrm{kDa}$ size range induce inflammatory gene expression in dendritic cells (83). Studies have shown that HA of $40-400 \mathrm{kDa}$ interact with HA-receptors to activate the NFKBmediated gene expression for endocytosis (84). Under certain conditions, HA fragments (20-200 kDa size) function as endogenous danger signals, while even smaller HA fragments $(\sim 2,500 \mathrm{kDa})$ can ameliorate these effects in cancer $(37,85,86)$. Thus, generation of HA fragments by HYALs (87) or by free radicals (88) during inflammation/tumorigenesis/tissue injury send the signals to the injured host that normal HA homeostasis is disturbed due to activation of different signal transduction pathways. The biological function of various sizes of HA is presented in Table $\mathbf{1}$.

Both physiological and pathological functions of $\mathrm{HA}$ are mediated by molecular interactions with CD44 and RHAMM and other HA-binding proteins (42). HA-rich glycocalyces anchored on cell surfaces by CD 44 and RHAMM can activate intracellular signaling pathways $(6,42,89)$, which can induce gene expression related to cell-cell adhesion, cell spatial orientation and trafficking, cell growth and differentiation, inflammation (11), wound healing and tissue remodeling $(11,80,90)$, tissue morphogenesis $(11,91)$ matrix organization, and many inflammatory pathologies $(6,7$, 19, 33-37, 92-100).

\section{HA in Inflammation}

The cell microenvironment has an important role in controlling inflammation. Prolonged inflammation leads to an influx of inflammatory cells, and it is increasingly clear that ECM degradation products are not only the result of inflammation but also can perpetuate inflammatory processes. LMW HA interactions with CD44 are associated with certain pathological conditions, including inflammation, cancer, and induction of angiogenesis $(23,33,101-103)$.

Hyaluronan chains can be organized into ECM structures by association with binding proteins. For example, HA cross-linking is essential to stabilize the cumulus-oocyte complex and is needed for successful ovulation and fertilization. The same mechanisms are likely to occur at sites of inflammation, where HA synthesis is upregulated $(104,105)$. Importantly, HA complexes of indeterminate sizes originate from the surface of multiple cells and can be coalesced into cable-like structures or HA fibrils at sites of tissue inflammation, viral infection, endoplasmic reticulum (ER) stress, and hyperglycemia. Monocytes/macrophages adhere to these HA inflammatory matrices and fragment them by a mechanism that 


\begin{tabular}{|c|c|c|}
\hline Sizes (kDa, or disachharide) & Function of $\mathrm{HA}$ & References \\
\hline $\mathrm{HA}$ size $>10^{6} \mathrm{Da}$ & $\begin{array}{l}\text { Space-filling, providing structural frameworks for cells, functions as an extracellular molecule transmitting } \\
\text { signals, and regulates a variety of cell behaviors, including cell adhesion, motility, and growth }\end{array}$ & $(6,8-11,37)$ \\
\hline $\mathrm{HA}$ size $>10^{6} \mathrm{Da}$ & Rapid matrix remodeling that occurs during embryonic morphogenesis, as well as tumorigenesis & $(4-7,27,37,63-69)$ \\
\hline HA size > 20 MDa & Ovulation, embryogenesis, wound repair, and tissue regeneration & (62) \\
\hline $\mathrm{HA}$ size $>10^{6} \mathrm{Da}$ & Tyrosine kinase in endothelial cells and Ras-transformed fibroblasts at lower level & $(70,71)$ \\
\hline $\begin{array}{l}\text { Extremely HMW HA (five times } \\
\text { larger than human HA) }\end{array}$ & Cancer resistance and longevity of naked mole rat & $(72,73)$ \\
\hline Excessive HMW HA production & Inhibit tumor growth, possibly by suppressing cell-cell interactions, or ligand access to cell surface receptors & \\
\hline HA size $<5 \times 10^{5} \mathrm{Da}$ & Cytokine and chemokine production for differentiation/activation of the macrophage & $(74-76)$ \\
\hline HA size $\sim 250,000$ & Induces inflammatory genes in renal tubular epithelial cells, T-24 carcinoma cells, and in eosinophils & $(77-79)$ \\
\hline $\begin{array}{l}\text { HA size } 8-16 \text { disaccharides } \\
(\sim 3200-6400 \mathrm{Da})\end{array}$ & Induce angiogenesis in a chick corneal assay whereas the native HA molecules do not & $(80-82)$ \\
\hline HA size $\sim 6-20 \mathrm{kDa}$ & Induce inflammatory gene expression in dendritic cells & (83) \\
\hline HA of $40-400 \mathrm{kDa}$ & NFkB-mediated gene expression for endocytosis & (84) \\
\hline HA size $\sim 2,500 \mathrm{Da}$ & $\begin{array}{l}\text { Upregulation of PTEN in tumor cells, and inhibit anchorage-independent growth as well as xenograft tumor } \\
\text { growth }\end{array}$ & $(37,86)$ \\
\hline
\end{tabular}

involves cell surface HYAL2 and CD44, which forms a cap on the surface while a portion of the HA matrix is internalized. Therefore, HA cross-linking represents an important new pathway in the regulation of inflammatory processes $(33,105-110)$.

One of the functions of HMW HA is to maintain water homeostasis and matrix structure (111). However, during inflammation, there is increased breakdown of HMW HA by HYALs (62), resulting in the accumulation of LMW forms that have different functions than their HMW precursors $(101,112)$ (see Figure 1). LMW HA is a potent activator of macrophages and airway epithelial cells (113-115). Specifically, LMW HA ( 200 kDa) can induce the expression of proinflammatory genes, such as macrophage inflammatory protein (MIP), keratinocyte chemoattractant (KC), macrophage chemoattractant protein-1 (MCP-1), and IFN induced protein-10, as well as cytokines, such as IL8, IL-12, and TNF- $\alpha(76,101,112,115-117)$. HA-stimulation of macrophages is associated with matrix-modifying enzymes (MMEs), inducible nitric oxide synthase (iNOS), and plasminogen activator inhibitor $(74,116,118)$. In addition, HA is also depolymerized by ROS, and the HA fragments are implicated in chronic inflammation (119). These HA-induced inflammatory mediators can enhance the inflammatory response that has already been set in motion, sending the system into a positivefeedback loop where inflammation promotes further inflammation, which, if unchecked, may eventually lead to fibrosis.

\section{HA in Cancer}

There is a complex cross-talk between cancer cells and their microenvironment. Strong evidence indicates that the tumor microenvironment can regulate the capacity of tumors to grow and metastasize (120). HA not only provides a cellular support and hydrophilic matrix but also regulates cell-cell adhesion, cell migration, growth, and differentiation (11). These properties make it a suitable candidate for involvement in pathological processes such as cancer. Furthermore, by forming pericellular coats, HA can protect tumor cells from immune attack (43,
44). Several tumor cells produce increased amounts of HA or induce the production of HA by the release of growth factors and cytokines. Such signals can regulate both HAS1, 3 and HYAL1. Similarly, ROS-induced fragmented HA also contributes to overproduction of HA (54). Likewise, both tumor cells and stromal cells express HAS isoforms and produce HA ECM, which then accumulates in tumor parenchyma and in the peritumor stromal tissues, which contributes to metastatic spreading (121125). Moreover, HA overproduction in tumor cells may induce EMT-like epithelial changes of cancer cells toward a migratory fibroblastic phenotype (126). HA-rich ECM may also mediate the recruitment of mesenchymal stem cells, which are progenitors of tumor-associated fibroblasts (127).

In addition, HAS1-3 synthesize HA of dissimilar sizes, which are linked to specific HA functions in wound injury $(37,125$, $128-131)$ as seen in keratinocyte wound repairs, and during mechanical injury in mesothelial cells $(73,132-136)$. Increased production of HA in non-malignant cells impairs contact inhibition of cell growth and migration (137). Likewise, forced expression of HAS2 and HAS3 genes results in HA overproduction, which enhances the tumor forming ability of fibrosarcomas and melanoma cells $(67,68)$ while abrogation of HAS2 blocks xenograft prostate tumor growth (69). Transgenic mouse models have shown that tumor-derived HA induces stromal reactions with subsequent promotion of tumor angiogenesis and lymphatic penetration within intratumoral stromal compartments (126). In addition, HA-rich tumor-associated micro-environments also accelerate the recruitment of inflammatory cells and the production of cytokines and chemokines, and the HA fragments generated by the degradation of HA can stimulate tumor growth and angiogenesis (82). Thus, targeting HA-tumor cell receptor interactions may identify promising therapeutic approaches in cancer treatment. In addition to interaction with cell surface receptors that initiate signaling pathways that impair vascular function (138), HA can increase interstitial fluid pressure and form a physical barrier against movement of small molecule 
therapeutics especially in pancreatic ductal adenocarcinomas (61). Thus, depolymerizing HA with HYAL may improve vascular function and ease movement of therapeutics.

\section{Interaction of CD44 and RHAMM with HA}

\section{Biology of CD44}

CD44 is a broadly distributed cell surface glycoprotein found on hematopoietic cells, fibroblasts, and numerous tumor cells. It was first identified as gp85 (14) and was then shown to be a HAreceptor in placenta cells when their adherence to immobilized HA was inhibited by an anti-CD44 monoclonal antibody, by soluble HA, and by HYAL $(16,139-142)$. However, the presence of the amino-terminal HA-binding region of CD44 does not guarantee that cells expressing CD44 will bind HA. Indeed, most CD44-expressing cells taken from normal animals, as well as from CD44+ cell lines, do not bind HA. Binding of CD44 to HA is cell specific and depends on the activation state of CD44 (143). CD44 has seven extracellular domains, a transmembrane domain, and a cytoplasmic domain (Figure 2) (144). The extracellular structure has two regions (amino acids 21-45 and amino acids 144-167) that contain clusters of conserved basic residues that have been implicated in HA binding, the BX7B motif. This motif, which is found in other HA-binding proteins, including RHAMM, is present as a single copy in the first of these regions, and as an overlapping pair in the second region (Figure 2). The pairs of intramolecular disulfide bonds are also crucial for HA-binding activity. The HA-binding domain located in the amino-terminal region is present in all isoforms (145). The membrane proximal region is less well conserved and contains the insertion site for the variant exon domains. The transmembrane and C-terminal cytoplasmic domains are highly conserved $(142,146,147$ ) (Figure 2).

CD44 is encoded by a single gene. Due to alternative splicing, multiple forms of CD44v are generated that are further modified by $\mathrm{N}$ - and O-linked glycosylation. The smallest CD44 standard isoform (CD44s) lacks variant exons, contains an N-terminal signal sequence (exon 1), a link module that binds to HA (exons 2 and 3), a stem region (exons 4, 5, 16, and 17), a single-pass transmembrane domain (exon 18), and a cytoplasmic domain (exon 20). In all forms of CD44 cDNAs, exon 19 is spliced out so that the transmembrane domain encoded by exon 18 is followed by the cytoplasmic domain encoded by exon 20, producing the 73 amino acid cytoplasmic domain. CD44s is found in most cells (6), whereas the isoforms that contain a variable number of exon insertions (v1-v10) at the proximal plasma membrane external region are expressed primarily on cells during inflammation and on tumor cells $(24,28,65,94)$ (Figure 2). More importantly, variants of CD44, specifically CD44v6, promote tumor progression and metastatic potential in lung, breast, and colon cancer $(6,24,94,95$, $148,149)$. Subsequently, several tumors, including colon cancer (150-154), Hodgkins lymphoma (155), gastric cancer (156), and melanoma (157), have been screened for CD44 isoforms, indicating that certain $\mathrm{CD} 44$ variants have crucial roles for tumor progression. HA and CD44s are present on the membrane of most vertebrate cells (65).

CD44 is a multifunctional receptor having diverse roles in cell-cell and cell-matrix interactions such as cell traffic, lymph node homing, prothymocyte homing, lymphocyte activation, cell aggregation, releasing chemokines and growth factors, and presenting them to traveling cells $(158,159)$. CD44 can be a proteoglycan with a potential chondroitin sulfate (CS) or dermatan sulfate (DS) substitution. Insertion of the $\mathrm{v} 3$ exon also includes the potential for heparan sulfate (HS) chain substitution (24), which can influence ligand binding and cell behavior by allowing CD44 to be a co-receptor for hepatocyte growth factor (HGF) with c-Met (160). The affinity of CD44 for these GAG substitutions depends on posttranslational modifications, such as oligosaccharide and GAG addition (161-163), and their subsequent functions depend on cell types and growth conditions $(6,24)$. These modifications can be altered by physiological stimuli, resulting in the induction of HA binding. In the immune system, HA binding can be induced in $\mathrm{T}$ cells upon antigen recognition (164) and upon monocyte activation by inflammatory stimuli $(51,52,147)$. Unlike HAS2 deficient mice (19), CD44-null mice develop normally, indicating that CD44 is dispensable for development (53).

In addition to binding to HA, CD44 can interact with several ECM proteins, including fibronectin, collagens, growth factors, cytokines and chemokines, and matrix metalloproteinases (MMPs) $(6,24,26)$. To contribute to pericellular proteolysis, CD44 facilitates activation of MMP-9 on the surface of carcinoma cells (165). CD44-mediated localization of MMP-9 on tumor cells can regulate tumor cell motility, growth factor activation, and survival mechanisms. It can also activate latent TGF $\beta$ and promote tumor invasion and angiogenesis (166) (Figure 3A). Tumor growth and metastasis is associated with increased levels of soluble CD44 (solCD44), which is detected in plasma from cancer patients (167), indicating increased proteolytic activity and matrix remodeling by CD44. Sol-CD44 is likely to affect cellular behavior by perturbing HA-CD44 interactions by acting as a sink for HA and may regulate cell migration by disrupting $\mathrm{CD} 44$-dependent cell-cell and cell-matrix adhesion. Cleavage of the extracellular domain of CD44 can be followed by subsequent proteolysis within the transmembrane domain and subsequent liberation of the CD44 intracellular domain (ICD) (168). The ICD can then translocate to the nucleus and promote transcription of CD44, providing a feedback mechanism for regulating CD44 expression (169) (Figure 3C).

Decades of research have shown that CD44 participates in major oncogenic signaling networks and in complexes with oncogenes that promote every aspect of tumor progression $(6,24)$. CD44 is extremely sensitive to changes in the microenvironment. For example, CD44 in breast cancer cells may act as a metastatic suppressor gene when influenced by ROS, as seen by decreased CD44 protein expression in the malignant and tumorigenic breast cancer alpha 5 cell line in a compensatory response to increased manganese superoxide dismutase (MnSOD) protein expression (170). Studies by Stoop et al. (171) showed that the cancerinitiating function in CD44-null mice was less severe, whereas the inflammatory functions were persistent in these mice suggesting again the possibility of a molecular redundancy in this model. Many of the contradictory findings published to date may be due to experimental and technical differences among studies. However, a picture has emerged suggesting that CD44 may function differently at different stages of cancer progression $(172,173)$. For example, mice with germline disruptions of CD44 display relatively mild phenotypes compared with mice in 
which tissue-specific CD44 function is disrupted at adult phases of development, or in later phases. This suggests that the absence of CD44 in early development and a loss of CD44 function late in development are tolerated differently (24). As CD44 is the major HA-receptor and a co-receptor for EGF, it was surprising to find that CD44-null mice had a mild phenotype. However, roles for this molecule in the immune system were revealed by a bacterial pneumonia model in which the null mice had enhanced edema and lung neutrophil accumulation (174). Therefore, CD44 appears to have a role in limiting inflammatory responses, which has also been shown in inflammation models (24).

Unlike CD44s, CD44v variants are only expressed on some epithelial cells during embryonic development, during lymphocyte maturation and activation, and in several types of carcinomas (175). In particular, upregulation of CD44v6 is an early event in carcinogenesis and requires adenomatous polyposis gene inactivation $(153,176,177)$. We found that overexpression of HAS2 in pre-neoplastic Apc10.1 cells induces CD44v6 expression, and the intestinal/colon tumors of Apc1 Min/+ mice express CD44v6 at substantially higher levels compared to expression of CD44s (94). A considerable number of studies indicate that CD44 variant isoforms correlate with bad prognosis in patients with most human cancers $(151,178-184)$ except in neuroblastomas and prostate cancer $(185,186)$. CD44v6 is quite likely to be a suitable target for anticancer therapy because it is: (a) causally involved in metastasis of a rat pancreatic carcinoma (187); (b) redundantly correlates with the human tumors mentioned above; and (c) correlates with oncogenic functions in colorectal cancer (CRC) both in vitro and in vivo $(6,94,178,180,181,188)$.

\section{CD44 in Inflammation}

The role of CD44 in the immune system was first found when immune responses were examined using monoclonal CD44 antibodies (mAbs) in wild type mice. KM201 blocked HACD44 interaction, whereas IRAWB14 enhanced HA binding. IM7 induced the shedding of CD44 from the cell surface and induced neutrophil depletion (189-192), indicating that in addition to blocking HA-CD44 interaction, CD44 mAbs can also alter HAindependent functions, such as interactions of CD44 and E- or L-selectin. These approaches support a proinflammatory role for CD44 $(193,194)$.

Other studies show that leukocyte rolling on inflamed endothelium is not only mediated by the selectin molecules, but can also be mediated by the interaction of T cell CD44 with HA on activated microvascular endothelial cells $(195,196)$. Moreover, CD44 and HA can facilitate the recruitment of neutrophils to sites of inflammation in some instances (197-199). Reduced recruitment of CD44-null macrophages to atherosclerotic lesions (200) indicates the contribution of CD44 to monocyte/macrophage recruitment to inflammation sites. CD44-null mice also experienced reduced levels of cerebral ischemia injury, further supporting a proinflammatory role for CD44 (201, 202). Studies also revealed that treatment with anti-CD44 mAbs reduced the severity of arthritis in a collagen-induced mouse model for human rheumatoid arthritis (RA) (203-205) and reduced the diabetic activity in NOD nice (206). The decrease in disease severity was associated with the delayed access of donor lymphocytes into the RA joints of recipient animals $(171,207)$. In human RA, CD44v5, CD44v6, and CD44v10 have been detected in synovial fluid and serum of patients $(208,209)$. In an inflammatory bowel disease (IBD) model, expression of CD44v7 is crucial for colonic inflammation $(210,211)$. Furthermore, CD44v6 expression is associated with IBD severity in patients (212-214). Extensive HA matrix accumulates in bleomycin-induced lung fibrosis in CD44-null mice with persistent lung inflammation, extended chemokine production, impaired clearance of apoptotic lymphocytes, and death (215).

Our recent study showed that a feedback loop between CD44v6 and TGF $\beta 1$ augments the fibrogenic functions of lung fibroblasts in interstitial lung disease (92). In this study, we showed that TGF $\beta$ promotes c-Met expression and CD44v6 expression that is accompanied by the CD44v6-induced formation of $\alpha$-SMA, increased cell proliferation and collagen production (Figure 3A). The CD44v6 signaling complex with TGF $\beta R I$ and TGF $\beta$ RII stimulates downstream SMAD signaling (Figure 3A). These findings provide clear evidence that TGF $\beta$ I initiates the signaling cascade through CD44v6 toward differentiation of fibroblasts to myofibroblasts (92). They do not exclude a further contribution of CD44v6 by activating the TGF $\beta 1$ proform through associated MMPs $(166,216)$. Overall, these studies indicate the critical involvement of CD44 and its variants in a number of inflammatory situations. However, the specific role of CD44 depends on the model system and the disease.

\section{CD44 in Cancer}

Although studies in vitro indicate that the tumor promoting function of HA partly depends on its molecular weight $(37,86,99,217)$, and on its capacity to interact with other proteins $(26,218)$, many of the tumor promoting activities of HA could be explained by its interaction with CD44. There are three ways how CD44 can interact with HA.

\section{CD44 Binds to Soluble Extracellular HA Molecules and ECM}

CD44 proteins exist in three states with respect to HA binding: non-binding, non-binding unless activated by physiological stimuli, and constitutive binding $(140,219,220)$. CD44 is endogenously expressed at low levels on various cell types in normal tissues (169), but it requires activation before it can bind to HA. Importantly, the minimal size of HA fragments binding to CD44 are six monosaccharide units (HA6). Thus, HMW HA in the ECM degraded by HYALs into smaller fragments can still bind to CD44 (221). Activated CD44 is overexpressed in solid tumors, but much less, or not at all on their non-tumorigenic counterparts. Adhesion of CD44 to HA induces upregulation of integrins that strengthen stem cell adhesion (222). Cross-talk between CD44 and CXCR4 signaling is a key role for HA and CD44 in CXCL12dependent trans endothelial migration of stem cells (223). Tumorderived cells express CD44 in a high-affinity state that is capable of binding and internalizing HA. Transitions from the inactive, low-affinity state to the active, high-affinity state by CD44 require posttranslational modifications, i.e., glycosylation in the extracellular domain and/or phosphorylation of specific serine residues in the cytoplasmic domain $(26,161)$ Such modulation of binding affinity of CD44 with HA is important for cellular migration that 
enables CD44 to be incorporated into the leading edge of the cells and lamellipodia (224).

CD44 can also react with other molecules, including collagen, fibronectin, osteopontin, growth factors (24), and MMPs in tumor cells $(167,225)$, but the functional roles of such interactions are less well known (24). Inhibiting cleavage of CD44 inhibits tumor cell migration on a HA substrate, suggesting that CD44 cleavage could release cells bound to a HA ECM (24). CD44 can also influence adhesion and de-adhesion to the ECM by regulating the pericellular HA matrix metabolism (226).

\section{CD44 Interacts with Receptor Tyrosine Kinases for Anti-Apoptosis and Drug Resistance}

Receptor tyrosine kinases (RTKs) are a subclass of cell surface growth factor receptors (GFRs) with an intrinsic, ligandcontrolled tyrosine kinase activity (227). The cytoplasmic domains of RTKs contain catalytic kinase activity and phosphorylation motifs that on activated RTKs assemble many intracellular signaling molecules. Apart from their activation by the auto phosphorylation of cytoplasmic subunits of RTKs, they are also activated by their association with several proteins, which are known as co-receptors of RTKs. These co-receptors do not have kinase activity, but they modulate the kinase activity of RTKs.

HA-CD44 or HA-CD44v interaction has a general effect on activation of cell survival anti-apoptotic proteins, which is initiated through the association with RTK activation. In malignant colon, prostate, and breast carcinoma cells, HA-CD44 interaction activates multiple RTKs, including ERBB2, ErbB3, EGFR, IGF1R- $\beta$, PDGFR- $\beta$, and c-MET, as well as assembly of lipid-raftintegrated signaling complexes containing these activated RTKs, CD44, ezrin, PI3-kinase (PI3K) and the chaperone molecules HSP90 and CDC37, which strongly promotes apoptosis resistance in cancer cells $(94,96,149,228-231)$. Increased HA production, however, induces RTK activation and signaling complex assembly in phenotypically normal epithelial cells (96). These macromolecular signaling complexes of CD44 also contain RhoA-specific guanine nucleotide exchange factor (p115RhoGEF), which is upstream of Grb2-associated Ras and PI3-kinase (98) and VAV2, which regulates cytoskeletal reorganization through RAC1 activation (232) (Figure 4A). A blockade of the HA-CD44 interaction causes macromolecular lipid-raft-integrated complex disassembly and inactivation of RTKs in various cancer cells including breast, colon, and prostate cancer (6, 19, 93, 96, 188, 228-231). CD44 also associates with non-RTKs, such as SRC, which has a central role by linking various extracellular signals to crucial intracellular signaling pathways (233). Thus, the lipid-raft location of CD44 is of particular importance for the involvement of CD44 in cell motility and signal transduction and accounts for the CD44-HAbinding-initiated cross-talk between RTKs, non-RTKs, and linker proteins $(234,235)$. In colon cancer, the HA-CD44v6 interaction and recruitment of ERBB2 also induces the transcription of COX2 initiated downstream of CD44 through PI3K-Akt and $\beta$-catenin $(93,188)$. COX2 further strengthens apoptosis resistance and HA-CD44 interaction through prostaglandin $\mathrm{E}_{2}$ expression (93, 188) (Figure 4B). CD44v6 also initiates MET activation through HGF binding. This requires the cytoplasmic tail of CD44 and the interaction with ezrin, radixin, and moesin (ERM) proteins for activation of the Ras-MAPK pathway (236). In addition, CD44v6 binding to the ECM also activates the PI3K-Akt pathway (237, 238) (Figure 4B) and regulates Met transcription (239).

Hyaluronan-CD44 cross-linking regulates drug transporter expression (228, 240-242). In addition, a positive-feedback loop, involving HA, PI3K, and ErbB2, augments MDR1 expression and regulates drug resistance in breast cancer cells (228) (Figure 4A). MDR1 is associated with CD44 in lipid microdomain and can be linked via CD44 with the actin cytoskeleton so that expression of both CD44 and MDR1 are concomitantly regulated (240) (Figure 4A). HA-CD44 binding promotes protein kinase $\mathrm{C} \varepsilon$ (PKCE) activation, and this increases NANOG phosphorylation and translocation to the nucleus (243). These events initiate the upregulation of MDR1, and then CD44 can associate with and stabilize MDR1 gene expression (244). In contrast, pro-metastatic miR-373-520c downregulates CD44 (245) indicating that oncogenic miRNAs can regulate CD44 cell behavior in a specific way.

\section{CD44 Can Act as Co-receptor}

CD44v6 can function as co-receptor for RTKs and alter the activation of GFR kinases. The CD44v segments contain some specific posttranslational modifications that include HS on a site in exon v3, which can bind proteins such as fibroblast growth factor 2 (FGF2). Such a function is not confined to HS-modified CD44v3 isoforms. It can also be provided by CD44v6 isoforms, which act as co-receptors, i.e., CD44v6 contains a binding site for RTKs, HGF receptor c-Met, vascular endothelial growth factor (VEGF) receptor VEGFR-2, proteins involved in cancer, and in fibrosis (92, 103, 236, 246, 247). Thus, HA interactions with CD44v can have a central role in RTK activated cell pathways that promote tumorigenic functions, including cell survival, through the RTK activation and consequent MDR1 gene activation. Importantly, activation of signaling pathways initiated by HA-CD44v interactions in the tumor matrix can be inhibited by HA degradation, by inhibiting HA binding to CD44v with small HA fragments, by blocking the CD44v HA-binding site, or by CD44v knockdown $(6,94,95,248)$. Further, blockade of an individual RTK does not recapitulate all of the effects observed when HA-CD44v interaction is inhibited (149). HYAL, as well as low molecular mass HA oligosaccharides (oHAs), also improves drug efficacy $(228,241)$ and drug transporter expression $(228,242,249)$ (Figure 8).

\section{Binding of CD44 to Actin Cytoskeleton}

CD44 and its associations with partner molecules, such as ERM proteins, participate in CD44-induced cell survival signaling, altered cell shape, and protein localization to the plasma membrane subdomains during cell migration (250). Ankyrin is involved in HA-CD44 dependent cell adhesion and motility. This involves binding of the $\mathrm{N}$ terminus of activated ERM to a motif between the transmembrane region and the ankyrin-binding site in the cytoplasmic domain of CD44, and subsequent binding of their carboxyl termini to filamentous actin (F-actin). This binds CD44 to cytoskeletal linker proteins, and this interaction is modulated by HA-CD44 interaction (251, 252). Overexpression of merlin, another member of the ERM family, inhibits subcutaneous growth of Tr6BC1 cells in immunocompromised Rag1 


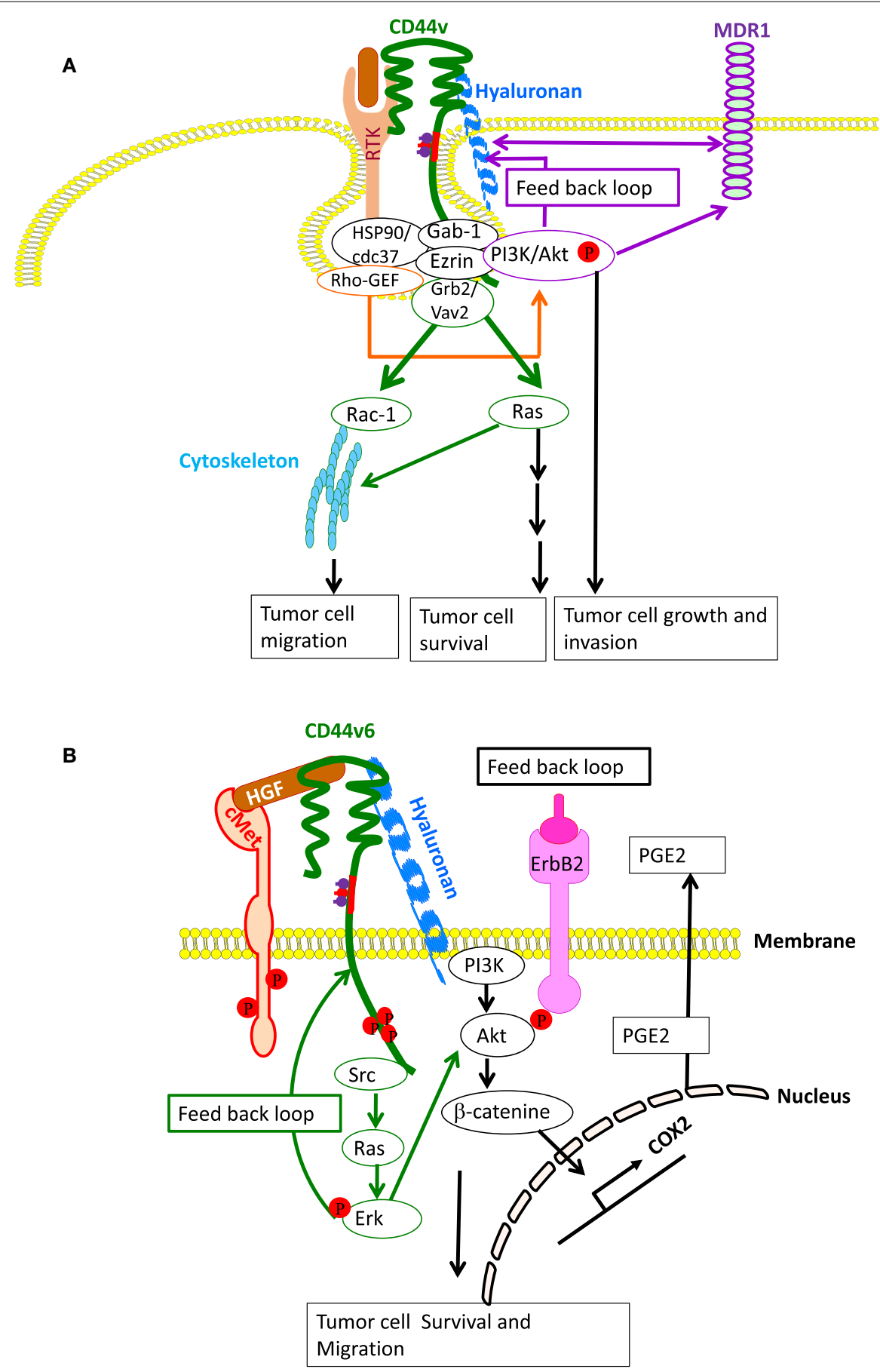

FIGURE 4 | CD44- and CD44v-induced RTK for apoptosis resistance. (A) CD44-HA binding, accompanied by activation of CD44-associated SRC, ezrin phosphorylation, and PI3K activation leads to the lipid-raft-integrated assembly of a complex that includes heat shock protein 70 (HSP70), the co-chaperone CDC37, Rho-GEF, Grb2NAV2, and Gab-1/PI3-kinase (PI3K), which promotes phosphorylation and activation of the receptor tyrosine kinases (RTKs), including ERBB2, ErbB3, EGFR, IGF1R- $\beta$, PDGFR- $\beta$, and c-MET. CD44-HA binding initiates cross-talk between RTKs, non-RTKs [SRC (Src)] and linker proteins. Studies have indicated that ErbB2 most likely complexes with CD44 via interactions with Grb2 and Vav2, whereas the interaction of PI3K and CD44 is mediated by Gab-1. PI3K activates Akt and downstream anti-apoptotic events, which contribute to drug resistance. However, HA and PI3K stimulate MDR1 expression, and the stimulatory effects of PI3K would be mainly due to its feedback stimulation of HA production by a positive feedback loop. Studies indicate that MDR1 is associated with CD44 in lipid microdomain and can be linked via CD44 with the actin cytoskeleton so that expression of both CD44 and MDR1 are concomitantly regulated. (B) Particularly, in colorectal cancer, the CD44-ERBB2 complex provides a strong apoptotic resistance through stimulation of cyclooxygenase 2 (COX2) transcription via PI3K and $\beta$-catenin. COX2-induced PGE2 stimulates HA synthesis and HA-CD44 signaling. CD44v6 also binds hepatocyte growth factor (HGF) and presents it to c-MET. Activation of MET and the downstream signaling cascades require sustained activation of CD44-associated phosphorylated ezrin, radixin, and moesin (ERM) and SRC (Src) signaling via the Ras-MAPK and the PI3K-Akt pathway. Ras-Erk pathway can augment CD44v6 synthesis through a feedback loop between CD44v6 and c-Met/Ras-Erk pathway. 
mice by negatively regulating CD44 function. In contrast, knocking down expression of endogenous merlin promoted tumor cell growth $(253,254)$.

\section{Biology of RHAMM}

Receptor for HA-mediated motility, an acidic and coiled-coil protein designated as CD168 (20), was first identified as a component of the HA-receptor complex in the conditioned media of murine fibroblasts $(21,22)$. It is located intracellularly in the cytoplasm, in the nucleus, and on the cell surface (255). There is no link module domain in RHAMM, but it includes a HA-binding region through the BX7B motif on its $\mathrm{COOH}$ terminus (27). RHAMM lacks a transmembrane domain but is GPI-anchored to the cell membrane, where it can interact with CD44 and participate in many cell functions, including cell motility, wound healing, and modification of signal transduction of the Ras signaling cascade (28, 256-259). Surprisingly, RHAMM contains no signal peptide and is thought to be transported to the cell surface via unconventional transport mechanisms, where it associates with the cell surface via docking with HA synthase (260), and like CD44, it transduces signals that influence cell motility $(28,30)$.

\section{RHAMM Signaling in Inflammation and Cancer}

Extracellular RHAMM interacts with protein tyrosine kinase receptors (RTKs) and non-protein-TK receptors, including PDGFR (29), TGF $\beta$ receptor-1 (261), CD44 (259, 262), CD44EGFR complexes (263, 264), bFGFR (265), and RON (266). These extracellular interactions can mediate motility necessary for inflammation through activation of ERK1/2/MAPK in the absence of intracellular RHAMM. Extracellular RHAMM can regulate cellular transformation and migration in an HAdependent manner. It can bind to CD44 on mesenchymal cells in wounds, which is necessary for the sustained activation and nuclear translocation of activated ERK1, 2, and for cell migration with increased mesenchymal differentiation within wound sites $(259,267)$.

Intracellular RHAMM binds to both actin filaments and microtubules in the cytoskeleton, in addition to interacting with ERK and SRC kinases $(30,268)$. Moreover, intracellular RHAMM also binds to a number of proteins, which can regulate microtubule dynamics and centrosome structure/function through ERK1/2/MAP kinase activation that contributes to microtubulemediated cell polarity and cell migration. Nuclear RHAMM also binds to ERK1/2/MAP kinase, which mediates activation of PAI1 and MMP-9 that are involved in cell motility and inflammation (132) (Figure 5). Secreted RHAMM can bind HA and, in concert with $\mathrm{CD} 44$, augment invasiveness in breast cancer. These interactions suggest that RHAMM may be necessary for CD44-mediated migration during inflammation, wound healing, tumorigenesis, and regulation of stemness/EMT phenotypes within tumor-initiating populations $(256,269,270)$. Intracellular RHAMM, both cytoplasmic and nuclear, interacts with several signaling proteins and cytoskeletal components, including SRC, ERK1, actin, and microtubules $(28,29,271)$. RHAMM regulates mitotic organization of microtubules through cytoskeletal elements aurora kinase A (AURKA), and BRCA1 (267, 272, 273), which is crucial for cellular fates, such as luminal differentiation and EMT. In addition, disruption of AURKA (274), BRCA1 (275), or RHAMM (276) modifies neurite extension, an alternate differentiation program dependent on microtubule nucleation (267) (Figure 5).

\section{Biology of HA-CD44/RHAMM Interaction}

Given the crucial role that HA has in cancer cell survival, proliferation, and invasion, it is clear that HA interactions with both CD44 and RHAMM can induce numerous cell behaviors, including activation of tyrosine kinases, protein kinase $\mathrm{C}$, FAK, and PI3K, MAPK, NFKB, and RAS, as well as cytoskeletal components required for inflammation and cancer $(6,24,28,132$, 277) (model in Figure 5). While CD44 and RHAMM can interact independently with HA to induce cell behavior, in some cases their relative contributions result in redundant and overlapping functions. For example, in a collagen-induced model of arthritis, inhibiting CD44 function attenuates the disease, indicating the involvement of CD44 (193). RHAMM is significantly elevated in the knee synovial tissue of patients with advanced osteoarthritis compared to those without (278). These results are consistent with animal model studies demonstrating an isoform-specific role for RHAMM in collagen-induced arthritis (193). The findings from Nedvetzki et al. (193) indicate that arthritis in WT mice is CD44 dependent, whereas in CD44-knockout mice, it is RHAMMdependent, as determined by antibody blocking and soluble peptide competition studies. This suggests that CD44 and RHAMM coexist in WT mice, but cell surface CD44 functions are dominant. Cell surface CD44 may primarily influence the joint inflammatory cascade in WT mice by its ability to quantitatively compete with cell surface RHAMM for HA and/or by its ability to regulate the potency of RHAMM-mediated signaling that may or may not be HA dependent. Absence of CD44 exacerbates bleomycin-induced lung inflammation in CD44-null mice due to accumulation of extensive HA ECM (215). In light of Nedvetzki's findings (193), the augmented lung inflammation/fibrosis in bleomycin-induced CD44-null mice (215) may be due to RHAMM (193). Further, HA accumulation was greater in the arthritic joints of CD44-deficient mice than in those of wild type mice where CD44 (but not RHAMM) promotes endocytosis of HA and its subsequent lysosomal digestion. The excess HA in CD44-null mice may contribute to prolonged signaling through RHAMM (28), which might lead to aggravation of the inflammatory lung fibrosis. Thus, the loss of the CD44 gene could be compensated with enhanced expression of RHAMM. Moreover, the loss of CD44 allows enhanced accumulation of the HA in ECM, with which both CD44 and RHAMM interact (193). In other words, this study indicates dual functions of CD44 in arthritis, one that causes disease initiation and another that limits disease severity, at least in part by reducing pathology promoting effects of RHAMM (193).

Similarly, in RHAMM null fibroblasts, migration is impaired due to reduced CD44 at the cell surface, and to impaired ERK1 activation and impaired wound healing (259). Interestingly, the dual functions of CD44 exist in cancer where tissue-specific expression of specific variant isoforms of CD44v appears to control progression of some cancers $(6,94,95)$, and these isoforms regulate tumor-initiating cells in sub populations of cancer cells 

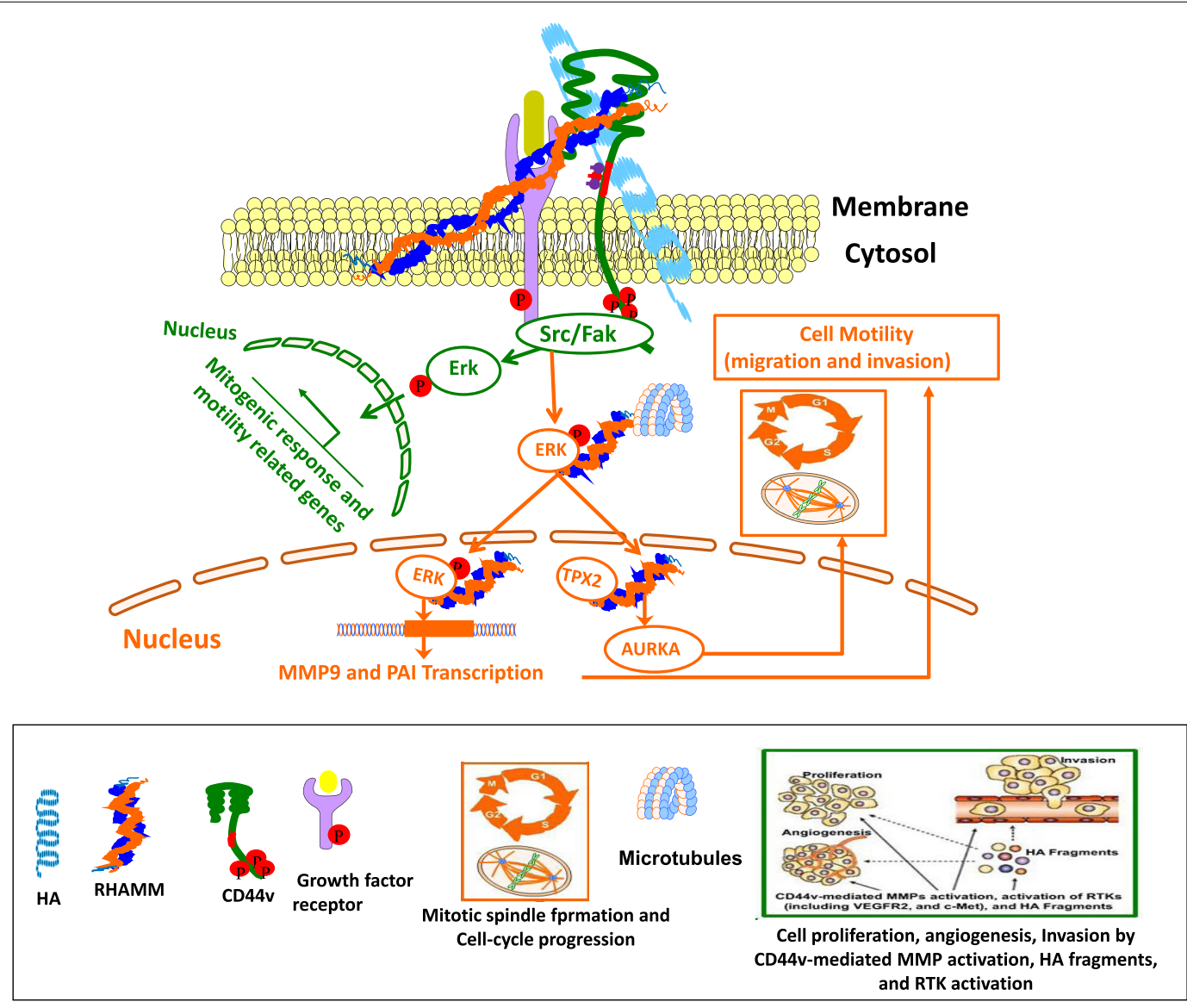

FIGURE 5 | Cross-talk between CD44 and RHAMM interaction with HA affects physiological and cellular functions. Green Track is for extracellular RHAMM signaling involving CD44-HA-mediated pathways. Red track is for intracellular RHAMM signaling. Studies suggest a model for functions of CD44 and RHAMM. The interaction of HA-CD44-RHAMM affects physiological and cellular functions. Cell surface RHAMM interacts with CD44, HA, and growth factor receptors (GFR) to activate protein tyrosine kinase signaling cascades that activate the ERK1/2 MAP kinase cascade in a c-Src/Raf-1/MEK-1/ERK1/2 dependent manner (depicted in green track). In the absence of intracellular RHAMM, this signaling can stimulate the transcription of motogenic effectors to regulate a mitogenic response (cell proliferation/random motility). In the presence of intracellular RHAMM (red track), MEK-1/p-Erk1/2 also binds to a number of protein partners that allows activated RHAMM to enter the nucleus to regulate functions of microtubule dynamics via centrosome structure/function, and cell cycle progression via AURKA, a targeting protein for XkIp2 (TPX2). Activated RHAMM also controls expression of genes involved in cell motility such as PAl-1 and MMP-9.
(149). Similarly, overexpression of RHAMM controls severity of carcinogenesis (e.g., breast cancer, CRC, multiple myeloma) (239, 255, 279), and loss of RHAMM regulates peripheral nerve sheath tumor progression (280), suggesting duality of RHAMM performance to maintain cell behavior. Studies also indicate that the oncogenic role of RHAMM can be limited through the activation of p53 (281). Further, RHAMM and CD44v isoforms coexisted in $65 \%$ of the cancer cases with another $23 \%$ having either RHAMM or CD44v expression. Recent studies demonstrated that RHAMM- and CD44-mediated cell adhesion and motility appear reciprocal rather than overlapping (282), whereas concurrent expression of CD44 and RHAMM genes might confer tumorigenicity of gastric cancer cells (283).

This section has reviewed evidence for secretion of intracellular regulators of mitosis and differentiation in the determination of cellular migration, tumorigenesis, and inflammation by overlapping and independent interaction of CD44 and RHAMM with HA (Figures 3-5). The presence and functions of these multifunctional HA-receptors have been examined both in diseased human tissues as well as in animal models of diseases. The modulation of these receptors may dramatically alter disease functions. The next section discusses the emerging cell-based strategies to target these molecules in inflammatory diseases, and particularly in cancer.

\section{Therapeutic Approaches to Interrupt HA Interaction with Receptors}

The inexorable course of progressive inflammation is similar in both the inflammatory diseases and in cancers. The seminal properties of these inflammatory and cancer cells involve cell adhesion, proliferation, migration, and invasion, and the HA-CD44 interactions can regulate these processes. Due to the unavailability of specific inhibitors, the physiological functions of HA have been mostly deduced from the biological changes caused by HA-receptor antagonists that can block the HA-CD44, 
TABLE 2 | HA-CD44-RHAMM function in inflammation and cancer

\begin{tabular}{|c|c|c|c|}
\hline Disease model & Function of HA in inflammation & Experimental approach by targeting HA-binding motifs & Reference \\
\hline $\begin{array}{l}\text { Bleomycin-induced lung } \\
\text { Inflammation in } \\
\alpha \text { SMA-HAS2 }{ }^{+} / \text {CD44-null mice }\end{array}$ & $\begin{array}{l}\text { Unremitting inflammation and death, } \\
\text { and accumulation of both HMW and } \\
\text { LMW HA }\end{array}$ & CD44 antibody (Ab) & (295) \\
\hline Excisional wound skin injury model & Acute and chronic skin inflammation & $\begin{array}{l}\text { 12-mer Pep-1 peptide } \\
\text { P15-1 peptide }\end{array}$ & $(132,297,306,307)$ \\
\hline $\begin{array}{l}\text { Staphlococcal aureus colonization of } \\
\text { incisional skin wounds }\end{array}$ & $\begin{array}{l}\text { Increased accumulation of CXCL1, } \\
\text { CXCL2 and neutrophils after skin injury }\end{array}$ & Pep-35 & $(304,305)$ \\
\hline $\begin{array}{l}\text { Bleomycin-induced lung injury mice } \\
\text { model }\end{array}$ & Inflammation and fibrosis in lung injury & RHAMM (HABP) and RHAMM-like Peptide A & $(295)$ \\
\hline Disease model & Function of HA in cancer & Experimental approach by using HA-drug carriers & Reference \\
\hline Bladder cancer & $\begin{array}{l}\text { G2-M arrest and apoptosis } \\
\text { Mitotic/oncogenic responses }\end{array}$ & $\begin{array}{l}\text { HYAL-1-v1 } \\
\text { HA ( 10-12kDa)-PTX conjugated drugs }\end{array}$ & $(312,316-318)$ \\
\hline EMT-6 tumor spheroids & $\begin{array}{l}\text { Increasing the accessibility to the } \\
\text { chemotherapeutic drugs }\end{array}$ & Bovine testicular or bacterial hyaluronidase & $(314)$ \\
\hline Pancreatic ductal adenocarcinoma & Reduction of metastasis & Soluble form of $\mathrm{PH} 20$ & $(60,61)$ \\
\hline $\begin{array}{l}\text { Colon, breast, esophageal, ovarian } \\
\text { prostate cancer }\end{array}$ & Mitotic/oncogenic characteristics & HA ( 200 kDa)-Irrinotecan conjugated drugs & $(320-322)$ \\
\hline Bone disease in cancer & Mitotic/oncogenic characteristics & HA ( 750 kDa)-5-FU, doxorubicin & $(323-325)$ \\
\hline Colon cancer & Mitotic/oncogenic characteristics & HMW HA-bisphosphonate & $(326)$ \\
\hline CD44 positive cancer & Mitotic/oncogenic characteristics & Nanoparticle delivery of chitosan-HMW HA & $(328-330)$ \\
\hline CD44 positive cancer & Mitotic/oncogenic characteristics & Lipid-HMWHA-mitomycin C (HA-LIP) & $(332-336)$ \\
\hline CD44 positive HNSCC & Mitotic/oncogenic characteristics & Micelles to deliver paclitaxol, doxorubicin, Salinomycin & $(338-340)$ \\
\hline $\begin{array}{l}\text { B16F10 murine melanoma and lung } \\
\text { carcinoma cells }\end{array}$ & Mitotic/oncogenic characteristics & HA-nanocarrier to deliver doxorubicin, epirubicin & $(335,341)$ \\
\hline Melanoma and breast cancers & Mitotic/oncogenic characteristics & Paclitaxel, mitomycin C, and various nanoparticles & $(316,341,343-350)$ \\
\hline
\end{tabular}

and HA-RHAMM interactions. Here, we describe the possibility for therapeutic approaches to interfere with HA-CD44-RHAMM interactions (Table 2).

\section{Role of HA, and HA-Receptors in Drug Conjugates}

The success of HA as a carrier depends on the number of receptors available on the target cells and on the affinity between the homing ligand and the receptor. HA preparations have been approved by the Federal Drug Administration as a medical device.

\section{HA-Preparations Used for}

\section{Non-Inflammatory/Non-Tumorigenic Therapies}

(i) A transdermal drug delivery of insulin using micro needles (MNs) fabricated with 15\% HA containing insulin is used in diabetes patients (284) (Table 2);

(ii) Transcutaneous immunization (TCI) of tetanus toxoid (TT) and diphtheria toxoid (DT) uses mixtures of sodium HA separately with $\mathrm{TT}$ and DT to form the MNs (285-288);

(iii) Antibodies against TNF- $\alpha$ or IL- $1 \beta$ conjugated to HMW HA diffuse slowly thus providing a sustained delivery of the antibodies in the wound (84);

(iv) Intra-articular injections have been used for the treatment of osteoarthritis of the knee, although further studies are required to establish its efficacy $(289,290)$; and (v) HA has been approved as a surgical aid in eye surgery (291) and to improve skin elasticity (292).

\section{Targeting HA and HA-Receptors in Anti-Inflammatory Therapies Using HA-Binding Peptide}

Recent investigations have taken advantage of the peptide-based probes to develop imaging agents to target HA-binding regions of HA-receptors (Table 2). HA, CD44, and RHAMM are known to regulate immunity during tissue repair, including innate immune cells such as macrophages, and fibrogenesis $(26,28,65,112$, $116,132,192,210,215,259,293-300)$. Thus, it is likely that HA-binding peptides can alter the HA-binding capacity of HAreceptors and modify disease processes such as tissue fibrosis, wound infection, contact hypersensitivity, and melanoma metastases in experimental models $(293,301-304)$.

CD44 and HA have been targeted for anti-inflammatory therapies using HA-binding peptides derived from a M13 phagedisplay library. One of these, Pep-1, which is a specific 12-mer HA-binding peptide, prevents leukocyte adhesion to HA (304) and inhibits leukocyte recruitment during contact hypersensitivity $(304,305)$. Pep-1 inhibits the binding of cells expressing HA-receptors (e.g., CD44) to immobilized HA substrate as well as the binding of soluble HA to cells expressing such receptors, implying that Pep-1 and HA-receptors compete for binding to the same ligand in acute skin inflammation (58). The peptide can also inhibit interleukin-2 induced vascular leak syndrome in mice 
by reducing damage to the endothelium, although lymphocyte migration was not affected (305). Pep-1 also inhibited secretion of the proinflammatory chemokine MIP-2 from HA stimulated macrophages (62). Studies on therapeutical aspects are currently under investigation that include the inhibition of enzymes that cleave CD44 (306) and CD44 vaccination (307), which provides partial resistance to experimental autoimmune encephalomyelitis (307). To date, no therapies have yet been developed that focus on augmenting the function of CD44 in the resolution of inflammation.

Using BLAST and ClustalX2, database searches between RHAMM and microtubule binding domains in microtubule binding proteins revealed only a moderate sequence homology of $17-24 \%$ to the HA-binding domain of RHAMM (295). Among the peptides, $\mathrm{P} 15-1$ preferentially binds oHAs $(<10 \mathrm{kDa})$ with a moderate affinity, and this peptide specifically mimics and blocks HA-RHAMM-induced FAK signaling, resulting in the healing of excisional wounds $(132,295)$. This peptide had no visible effect on incisional skin injury repair, which is consistent with genetic deletion of RHAMM, which affects excisional but not incisional skin injury $(259,295,308)$. Pep-35, which encodes two RHAMM HAbinding sequences, also reduced Staphylococcus aureus colonization of incisional wounds (302) by increasing the number of neutrophils and their expression of CXCL1 and CXCL2 after injury (303). Short peptides of RHAMM [hydrazide group to bisphosphonate (HABP)] and RHAMM-like (peptide A) also reduced inflammation and fibrosis in lung injury models by reducing macrophage migration and accumulation, and by reducing hydroxyproline (collagen) content in the lungs of the bleomycin injury mouse model (293). Similarly, RHAMM HA-binding peptides inhibited arthritis formation in collagen-induced arthritis in mice (193). These studies suggest that blocking HA-RHAMM, or HA-CD44 interactions could have therapeutic benefits in inflammation and wound repair disease processes in light of the dual roles of CD44 in the inflammatory response as discussed above $(202,216,309)$ in specific diseases.

\section{HA-Drug Conjugates in Cancer Enzymatic degradation based therapeutics of $\mathrm{HA}$}

Hyaluronidases are a class of enzymes that predominantly degrade HA (Table 2). Recently, Lokeshwar et al. have shown that the expression of HYAL-1-v1 in bladder cancer cells that express wild type HYAL-1 induces G2-M arrest and apoptosis (310). It has been shown that adhesion of monocytes to human coronary artery smooth muscle cells was also inhibited by bacterial HYAL (311). Similarly, commercial bovine testicular or bacterial HYAL act as an anti-adhesive compound on EMT-6 tumor spheroids (312), and HYAL disaggregated EMT-6 spheroids increased chemosensitivity to cyclophosphamide (312), and also improved the therapeutic effectiveness of these agents, i.e., by increasing the accessibility of solid tumors to the chemotherapeutic drugs. Unlike EMT-6 cells, HYALs have limitations as an anti-adhesive agent for other human tumors (313) and can have side effects that impact normal tissue functions.

Development of a recombinant soluble form of PH20 (60) has paved the way for drug delivery in otherwise non-penetrable pancreatic ductal adenocarcinomas where HA forms a formidable barrier in the tumor stroma. Intravenous administration of PEGPH20 restored normal interstitial fluid pressure in the tumor by increasing vessel diameter. A prospective, randomized, placebo control trial in KPC mice with combined enzymatic and gemcitabine treatment has shown $83 \%$ increase in median survival rate. $80 \%$ placebo control mice died vs. $29 \%$ of Gem + PEGPH20 treated mice, and significant reduction of metastatic tumor burden was observed with combined therapy (61).

\section{HA backbone-based conjugated drugs in cancer}

Hyaluronan conjugated drugs are more soluble in water than the drugs alone (Table 2). For instance, the antimitotic chemotherapeutic agent paclitaxel (PTX) has low water solubility. Upon conjugation to HA, water solubility of the prodrug HA-PTX, and of HYTAD1-p20 (a HA-PTX conjugate renamed as ONCOFID$\mathrm{P}$ by the pharmaceutical company Fidia) significantly increased CD44 dependent cellular uptake in vitro and in vivo in cancer cells, including bladder carcinoma cells $(314,315)$. Luo and Prestwich coupled PTX-N-hydroxysuccinimide ester (PTX-NHS) with HA of molecular weight $\sim 11 \mathrm{kDa}$ (316). PTX release from the hydrogel film was evaluated in vitro using selected anti-bacterial and antiinflammatory drugs (317). The pharmaceutical company Fidia prepared $\mathrm{ONCOFID}^{\mathrm{TM}}-\mathrm{S}$, another HA prodrug conjugate with SN-38, the active CPT11 (irinotecan) metabolite. The HA used had a molecular weight of $200 \mathrm{kDa}$. In vitro and in vivo phase I and phase II clinical studies were initiated using ONCOFID$\mathrm{S}$ in several CD44-overexpressing cancer cells, including colon, gastric, breast, esophageal, ovarian, and human lung cancer cells. In all these studies, these drugs reduced tumor cell growth and metastasis (318-320).

\section{HA-encapsulated drugs}

Another strategy for HA-based CD44 targeting utilizes the concept that the large volume domain of HA (molecular weight $>750 \mathrm{kDa}$ ) can non-covalently entrap small therapeutic molecules within its domain (Table 2). HA was then used as a macromolecular carrier for the irinotecan drug along with its targeting properties (321). Clinical trials of three HA formulations [termed hyaluronic acid chemo transport technology (HyACT)] have been undertaken in Australia. Phase I clinical evaluation of two formulations based on HA (HyACT) with 5-fluorouracil (5FU) (known as HyFIVETM), and on HA (HyACT) with doxorubicin (DOX) (known as HyDOXTM) demonstrated reasonable cytotoxic efficacy without compromising safety of these formulations $(322,323)$.

\section{HA-tailed drug carriers}

These include the following HA conjugates with cytotoxic activity (Table 2).

(i) Bisphosphonates (BPs) - where HMW HA is linked via a HABP (324).

(ii) Carbonates (HA-pCB) - where $n$-propyl carbonate is linked to $\mathrm{HA}$ via an ester linkage $(325,326)$.

(iii) Chitosan - where chitosan-HA nanoparticles (HA-CTNPs) containing 5-FU/oxaliplatin were prepared by the ionotropic gelation method. 5-FU/oxaliplatin loaded HA-CTNP formulation significantly enhanced cytotoxicity compared with 
either chitosan nanoparticles (CNTPs) alone or free 5-FU, or oxaliplatin in HT29 CRC cell lines, which overexpress CD44 $(327,328)$.

(iv) Gagomers (GAG-mers) - where GAG-mers (GAG cluster of particles) are composed of lipid molecules that self assemble into particulate clusters in hydrophilic solutions, which are then covalently coated with HMW (1.2-5 MDa) HA. When tested in primary head and neck cancers and normal cells taken from the same patient (329), GAG-mers selectively bound only to the tumor cells to induce cytotoxic activity.

(v) Liposomes/lipoplexes (HA-LIP) (330-334) - where HMW HA was decorated on nano-sized encapsulated mitomycin $\mathrm{C}$ (MMC). The cytotoxic activity of the drug loaded into HALIP was found to be $\sim 100$-fold that of free drug in in vitro and in vivo tumor cells overexpressing the HA-receptors, but not in cells with low receptor expression levels. The HA-LIP conjugate can be used to deliver plasmid DNA and small interfering RNA (siRNA) to CD44 positive cancer cells (332, 335). The presence of HMW HA in the lipoplexes enhanced nucleic acid protection from degradation by DNase I or RNAse VI. In case of LMW HA, the HA was linked to $\mathrm{PE}$ to form a conjugate in which only one $\mathrm{PE}$ molecule is linked to a HA molecule $(333,334)$. This procedure enables a controlled amount of HA to be introduced into the liposomes. oHAs were attached to PE and incorporated into the liposomes, which increased their recognition, cytotoxicity, and transfection efficiency by tumor cells expressing high levels of CD44 in a temperature-dependent manner.

(vi) Micelles - where the hydrophilic backbone of HA was conjugated via its carboxyl groups to amino functions of poly-L-histidine (PHis) or polyethylene glycol (PEG). These HA constructs form nanocomplexes by self-organizing into micelles, and they can carry anticancer drugs, including PTX. In addition, PTX when entrapped into the hydrophobic cores of the folic acid (FA)-conjugated HA-C18 micelles exhibited higher cytotoxic activity compared to Taxol in MCF-7 cells that overexpress both the folate receptor and CD44. The micelles of HA-PTX (336), HA-DOX (337), and HA-salinomycin (338) exhibited more pronounced cytotoxic effects on HA-receptor overexpressing cancer cells than on receptor deficient cells.

(vii) Nanocarrier - where HA was conjugated to a nanocarrier. These nanoparticles were able to deliver anticancer drugs, including epirubicin (339), DOX (333), PTX (314), and MMC (339), as well as siRNA, to CD44 overexpressing cells (340). In addition to the well-developed strategies described above, several multifunctional nanocompounds have recently been developed that combine therapeutic and diagnostic properties. These nanoparticles include quantum dots (341), carbon nanotubes (342) and nanodots (343), graphene (344), gold nanoparticles (345), iron oxide nanoparticles (346), and silica nanoparticles (347), and they have been found to acquire novel characteristics after their conjugation with HA (341-348) (Table 2).

\section{Targeting CD44 in Cancer}

HMW HA can interact with a number of CD44 receptors and be endocytosed. It is rapidly cleared from circulation by the liver hepatocytes (349), and any excess of the targeting compound can lead to adverse effects (350). This rapid clearance was circumvented by choosing oHAs long enough to bind to CD44 but too short to bind to the HARE receptor, which may permit targeting to cells that overexpress CD44. The minimum HA length required to interact with individual CD44 molecules is 6-10 monosaccharides (220) with moderate affinity.

\section{Interrupting HA-CD44 Interaction}

As mentioned in the previous sections, the main property attributed to CD44 is its ability to bind HA, and this binding contributes to apoptosis resistance of cancer-initiating cells (6, 37, 351-353) (Table 3; Figure 6). There are also examples in which CD44 cross-linking initiates apoptosis. However, apoptosis induction by HA-CD44 cross-linking is largely restricted to non-transformed cells with immature leukocytes being most easily affected. Thus, together with the oncogenic transformation and the pronounced association of CD44 with oncogenes, HACD44 cross-linking initiates signals that promote cell survival in tumor cells. The cross-talk of CD44 with multidrug resistance genes accounts for an alternative CD44-mediated apoptosis resistance mechanism This approach involves substituting multivalent interaction of HMW HA with CD44 with monovalent interaction of small oHAs [6-18 saccharide units (oHAs)] $(217,354)$. The oHAs inhibit HA-CD44 downstream cell survival and proliferation pathways, and they stimulate apoptosis and expression of phosphatase and tensin homolog (PTEN) (86, 355). The oHAs also sensitize cultured cancer cells to some chemotherapeutic drugs by inhibiting expression of MDR1 and other ABC transporters $(96,228,241)$. While oHAs inhibit the growth of several tumors implanted as xenografts (86), they did not give consistent significant growth inhibition in adenoma growth in Apc Min/+ mice (Misra et al., unpublished results). There are several studies contradicting the cellular response of HMW and LMW HA. For example, in schwannomas cells, HMW HA inhibited tumor growth (356). In contrast, LMW HA can induce angiogenesis (80) and inflammatory responses in various cell types $(76,112,357)$. These inconsistencies could be resolved if the HA preparations and size determinations could be done properly and if the receptors, or the signaling pathways were identified properly. Only a few studies define the receptors (93, 232). Thus, we developed siRNA and, even more advantageous, short hairpin RNA (shRNA), to target CD44v6 in colon cancer, and showed that they can successfully interrupt HA-CD44v6 interaction and signaling ( $90-95 \%)$. We then developed a novel shRNA delivery approach to target HA-CD44v6 specifically in tumor cells $(6,94,95,248)$, which is discussed in the following sections.

Overexpression of sol-CD44 displaces exogenous HA from its binding to CD44 and thereby retards tumor cell growth both in vitro and in vivo, and sensitizes tumor cells to chemotherapeutic drugs $(228,229,353,358,359)$. However, soluble forms of CD44 can differ in their capacity to bind HA, indicating that sol-CD44 can act as a competitive inhibitor of exogenous 
TABLE 3 | CD44 function in cancer

\begin{tabular}{|c|c|c|c|}
\hline Disease model & Function of CD44 in cancer & Approaches to interfere the HA-CD44 interaction & Reference \\
\hline $\begin{array}{l}\text { Colon, breast and prostate } \\
\text { cancer cells }\end{array}$ & Apoptotic resistance & HA oligosaccharides [6-18 saccharide units (oHAs)] & $\begin{array}{l}(86,96,219,230 \\
243,356,357)\end{array}$ \\
\hline Schwannomas cells & Inhibition of cell survival & HMW HA & $(358)$ \\
\hline $\begin{array}{l}\text { Xenografts of mammary } \\
\text { and colon tumor cells }\end{array}$ & Cell survival & Soluble CD44 & $\begin{array}{l}(166,230,231 \\
355,360,361)\end{array}$ \\
\hline HNSCC & In vitro and in vivo malignant properties & $\begin{array}{l}\text { Anti-CD44-Mo-Ab conjugated with mertansine, or } \\
\text { radionucleotide, activated anti-CD44 antibody (H90) }\end{array}$ & $(152,369-373)$ \\
\hline AML cells & Tumor cell survival activities & CD44v6 peptides containing the v6 exon region & $(373)$ \\
\hline Colon cancer cells & Tumor cell survival activities & $\begin{array}{l}\text { Penetratin-conjugated peptide, and peptide specific } \\
\text { for CD44 }\end{array}$ & $(103,374,375)$ \\
\hline $\begin{array}{l}\text { Melanoma and prostate } \\
\text { tumor cells }\end{array}$ & In vitro cell migration, invasion & Pep-1 (specific 12-mer HA-binding peptide & $(379)$ \\
\hline Melanoma tumor cells & $\begin{array}{l}\text { Melanoma tumor cells growing under both anchorage- } \\
\text { dependent and -independent conditions melanoma } \\
\text { tumor growth in nude mice xenograft models }\end{array}$ & $\begin{array}{l}\text { BHP ( } 42 \text { amino acid peptide containing three BX7B } \\
\text { HA-binding motifs) peptide }\end{array}$ & $(362)$ \\
\hline Disease model & Function of CD44 in cancer & Systemic targeting by viral and non-viral vectors & Reference \\
\hline $\begin{array}{l}\text { Ornithine transcarbamylase } \\
\text { deficient sparse fur mice }\end{array}$ & Tumor cell growth in vitro and in vivo & Viral vectors & (389) \\
\hline K562 cells & Tumor cell growth in vitro and in vivo & Non-viral vectors & $(390,391)$ \\
\hline $\begin{array}{l}\text { Intestinal tumors in Apc } \\
\text { Min/+ mice }\end{array}$ & Tumor cell growth in vitro and in vivo & $\begin{array}{l}\text { Tissue-specific delivery of non-viral CD44v6 } \\
\text { shRNA-nanaoparticle }\end{array}$ & $(94)$ \\
\hline
\end{tabular}

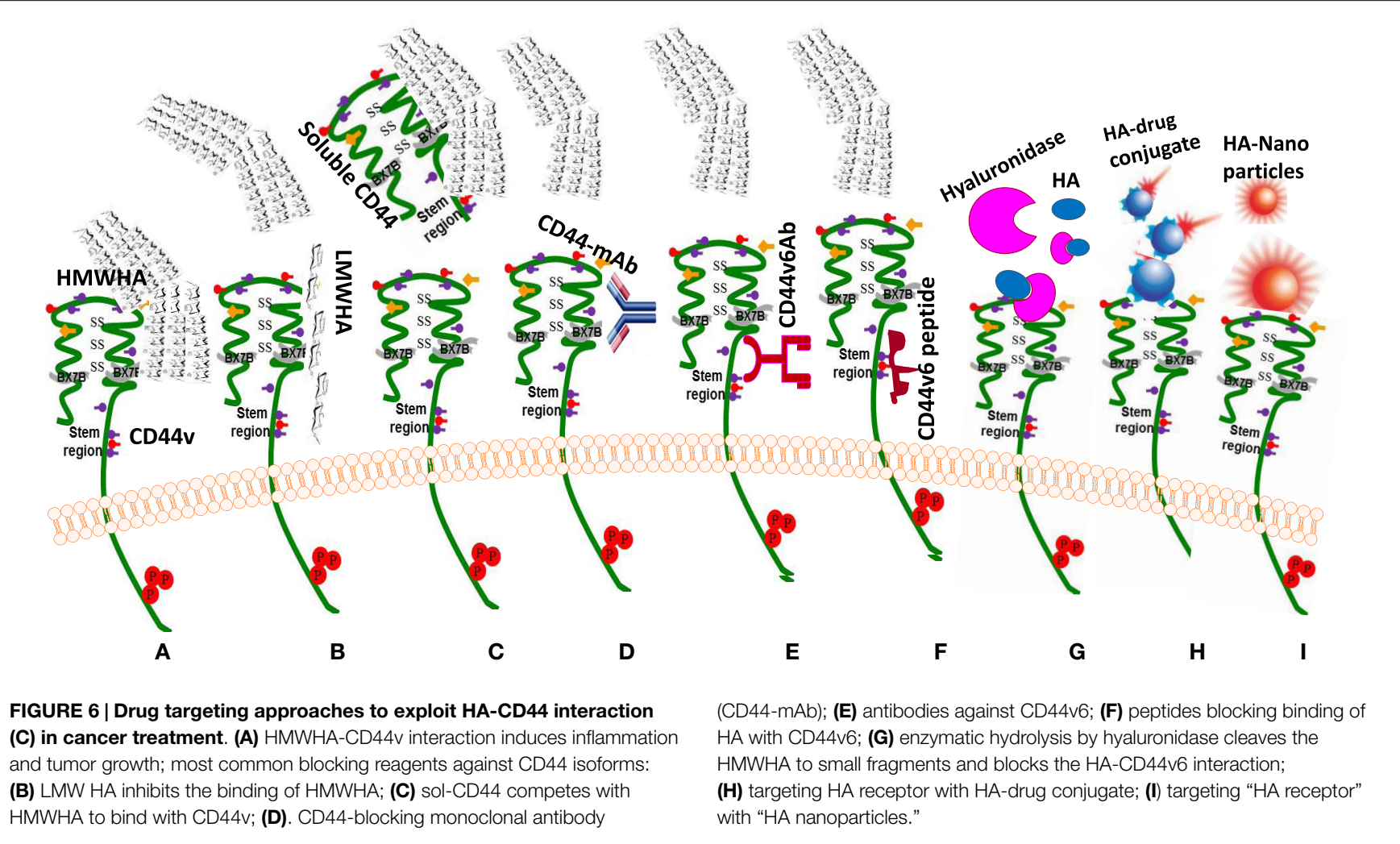

HA-protein interactions. In these studies, sol-CD44 blocks HAactivated CD44 clustering and inhibits CD44-mediated recruitment of activated MMP-9 and invasion potential of cancer cells
(165). Similar to HA-binding sol-CD44, a peptide (42 amino acids in length) enriched with three HA-binding motifs (BX7B) possesses an antitumor activity in melanoma cancer (360). 


\section{Targeting with Anti-CD44 Antibodies}

Anti-CD44 antibodies against highly expressed CD44v variants can effectively target drugs to cells expressing a selective CD44v, which can then inhibit and disrupt CD44 matrix interactions, alter CD44 signaling, and cause apoptosis (361) (Table 3; Figure 6). Antibodies against highly expressed variants can also be designed to selectively deliver a cytotoxic drug to cancer cells in two different ways. They can bind and neutralize the receptor by competitive inhibition of its ligand and hence stop the receptor-signaling cascade. They can also be attached to radioisotopes, toxins, or chemotherapeutic agents and target them to the required vicinity. The first concept has been effectively utilized for other receptors like anti-EGFR antibodies cetuximab, panitumumab, etc. Anti-CD44v6 conjugated with a cytotoxic drug mertansine has been extensively studied in early phase clinical trials for its value in translational medicine (362-366). Head and neck squamous cell cancer (HNSCC) patients were treated with three doses of mertansine conjugated bivatuzumab (humanized anti-CD44v6 monoclonal antibody [HAMA] labeled with technetium-99m) was first tested (151, 367, 368). However, the phase I clinical trials were rather disappointing in terms of accumulation and toxicity. Furthermore, dose limiting skin toxicity was observed, most probably due to CD44v6 expression in non-tumor skin areas, indicating limitations in the use of this antibody therapy. However, given the promising results of a phase I clinical study with the radionuclide-antibody conjugates (362-366), new similar conjugates of bivatuzumab with radioisotopes were found to be safe and effective in phase I trials $(369,370)$, and a conjugate of immunotoxin with bivatuzumab (369) was also found to be safe in the next clinical trial on 30 HNSCC patients. In this context, a previous study showed that activated anti-CD44 antibody (H90), when used in human acute myeloid leukemia (AML) cells, reduced the leukemic repopulation by altering the fate of AML leukocyte stem cells (AML LSC), and by abrogating AML LSC homing, leading to their death (371). This study suggests that activated anti-CD44 antibodies without conjugation with toxin are much safer and efficient for antitumor activity. Thus, CD44, particularly CD44 variant forms, remains a crucial target for tumor therapy (Figures 4 and 5). To address this issue, we have developed a novel tissue-specific (CD44v6) shRNA delivery strategy by a Cre-lox system. This technology is discussed in a following section.

\section{Peptide-Based Strategies}

It is becoming increasingly evident that future prospects for the treatment of inflammation/cancer should include the targeting of specific signaling pathways in tumor cells. (Table 3; Figure 6) CD44v6 is a co-receptor for VEGF/VEGFR-2 and HGF/c-Met, and mutational analysis of CD44v6 revealed that three amino acids in the v6 region are required for its co-receptor function for Met and VEGFR-2. These studies helped to identify CD44v6 peptides with the minimal length of five amino acids that contain the critical v6 exon region that can inhibit both VEGFR-2 and cMet activation. This inhibits the co-receptor function of CD44v6 and the vascularization and tumor cell growth, migration and invasion $(103,372)$.
Serine phosphorylation of the human CD44 cytoplasmic tail at Ser323 and Ser325 enhances cell migration potency. Thus, a penetratin-conjugated peptide containing phosphoserine at residue 325 reduced in vitro migration of melanoma cells (373). Insertion of phosphorylated Ser325 (pSer325) or pSer323 and pSer325 in the peptides disrupted the activation of CD44/MMP-9 signaling complex in prostate cancer cells (374). Another peptide comprising eight amino acids that bind specifically to CD44 (375) and derived from human urokinase plasminogen activator (A6) inhibits migration, invasion, and metastasis of cancer cells by interfering with an uPA-independent signaling pathway (376).

The Pep-1 (specific 12-mer HA-binding peptide) peptide can reduce lung metastasis and prolong survival of mice injected with cell line-derived melanoma cells (377). Besides this Pep1, BH-P, a 42 amino acid peptide containing three BX7B HAbinding motifs present in CD44 can exert antitumor effects by inhibiting the proliferation of melanoma tumor cells growing under both anchorage-dependent and -independent conditions and by inhibiting melanoma tumor growth in nude mice xenograft models (360).

\section{Tissue-Specific Deletion of CD44variant Signaling}

CD44 splicing can regulate interaction with HA $(378,379)$ (Table 3; Figure 6). HA is not only the essential component of the tumor matrix assembly (380), but also has a crucial role in cancer stem cell (CSC) niches, which are particularly rich in HA (381). Interference in matrix components alters signaling events of tumor-initiating cells such that tumor cells that express HA can induce expression of HA in other cells that make up the CSC niche $(382,383)$. In addition, CD44v6 isoforms are engaged in matrix assembly (384) and have been identified as markers of CSCs in colon cancer, and they account for the metastatic susceptibility of the tumors (385). In the intestinal mucosa, CD44 is a major direct target of $\beta$-catenin mediated transcription (177), and we have shown that CD44v6 also regulates $\beta$-catenin in colon cancer cells (93). Furthermore, CD44v4-v10, but not CD44s, is a crucial component of the intestinal stem cells in the crypts of ApcMin/+ mice, and controls tumor initiation and relapse by controlling the balance between cell survival and apoptosis (178). These studies indicate that CD44v6 targeting in colon cancer is a promising therapeutic approach. The inhibition of CD44 mRNA expression by inducing the expression of siRNA/shRNA in tumor cells is an alternative approach to the use of CD44blocking antibodies to interfere with the function of CD44 proteins. This section discusses the fundamental aspects of a therapeutic approach targeting CD44v6 by means of colon cancer cell-specific delivery of shRNA. This approach addresses: (a) what to deliver (engineered therapeutic CD44v6 shRNA), (b) how to deliver (delivery strategies using non-viral transferrin (Tf)coated PEG-polyetheleneimine (PEI) (Tf-PEG-PEI) nanoparticles for in situ cell-specific therapy), and (c) where to deliver (tumor cell targets, in particular, colon tumor cells for in situ cell-specific therapy). The technique of using shRNA in an expression vector is an alternative strategy to stably suppress selected gene expression, which suggests that the use of shRNA expression vectors holds potential promise for therapeutic approaches for silencing disease causing genes (386). There are two ways to deliver shRNA in 
cancer cells, either using a viral vector or a non-viral vector. Viral vectors have been used to achieve proof of principle in animal models and, in selected cases, in human clinical trials (387). Systemic targeting by viral vectors toward the desired tissue is difficult because the host immune responses activate viral clearance. Systemic administration of a large amount of adenovirus (e.g., into the liver) can also be a serious health hazard and even caused the death of one patient (387). Nevertheless, there has been considerable interest in developing non-viral vectors for gene therapy.

Figures 6-8 illustrate the model for the uptake of non-viral vectors through Tf-PEG-PEI-nanoparticles carrying multiple functional domains. Non-viral vectors mediate unspecific interactions with non-target cells and blood components, which results in the rapid clearance from circulation. PEI has positive charges and binds to negatively charged plasmid DNA to form condensed particles. The PEG shields the condensed PEI-Plasmid particles from unwanted interactions and prevents clearance from circulation thus giving longer half-life (388). To increase the transfection efficiency of the shielded particles (plasmid DNA/PEG-PEI), different targeting ligands, such as peptides, growth factors and proteins, or antibodies, have been incorporated into the vectors (389). One such targeting ligand is Tf, an iron-transporting protein that is recognized by Tf receptors (Tf-Rs). Association of Tf to polyplexes enhances transfection efficiency (389). This concept was tested by preparing non-viral vector Tf-PEG-PEInanoparticles with plasmids packed inside an outer PEG-PEI layer coated with Tf that binds with Tf-R with high affinity in the tumor cells $(94,389,390)$ (depicted in the model in Figure 7). We found that the Tf- $\mathrm{R}$ is present at much higher levels on the tumor cells than on phenotypically normal epithelial cells (94). Tf-PEG-PEI-nanoparticles significantly enhance transfection efficiency of CD44v6 shRNA generator plasmids by promoting the internalization of the nanoparticles in proliferating and nonproliferating colon cells through receptor-mediated endocytosis $(94,389)$. Therefore, the uptake of Tf-PEG-PEI-nanoparticles carrying multiple functional domains (surface shielding particles Tf-PEG-PEI, CD44v6 shRNA generator plasmids, tissue-specific promoter driven Cre recombinase plasmids, and conditionally silenced plasmids) can overcome the intracellular barriers for successful delivery of the CD44v6 shRNA (94).

This CD44v6 shRNA plasmid delivery approach was tested for transfection of pSV- $\beta$-gal/Tf-PEG-PEI-nanoparticles in cellular models $(6,94,248)$ (Figure 7$)$. Following this experiment, we successfully demonstrated that the CD44v6 shRNA is localized into the colon tumor cells by an end point assay of CD44v6 expression and by perturbation of HA-CD44v6 interaction as reflected in the reduction in the number of tumors (94).

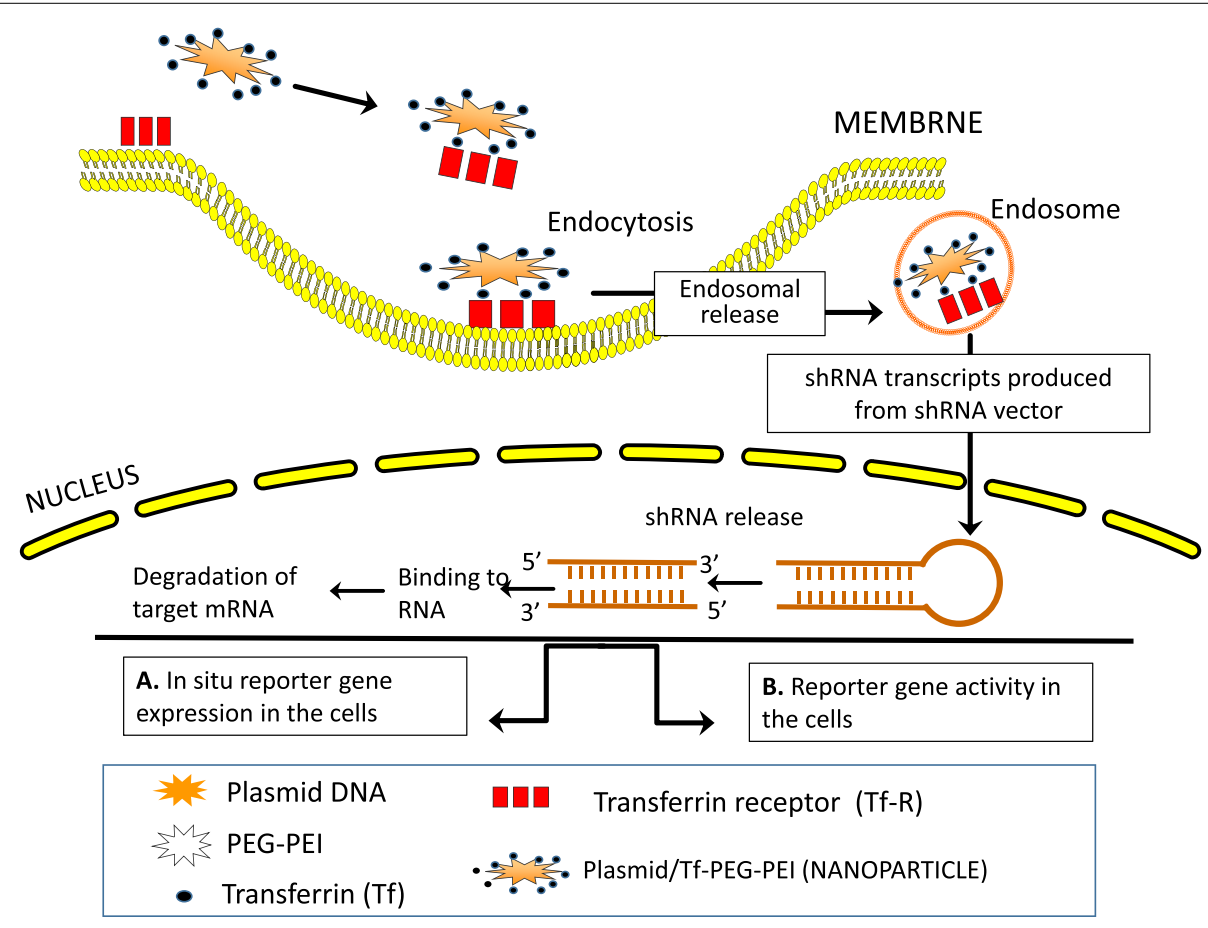

FIGURE 7 | Schematic illustration of cellular uptake of plasmid DNA/Tf-PEG-PEI (nanoparticles) polyplexes, their shielding from non-specific interaction, and the mechanism of action of shRNA. Internalization of PEG-shielded and [transferrin receptor (Tf-R)]-targeted polyplexes into target cells occurs by receptor-mediated endocytosis after association of polyplex ligand Tf to Tf-R present on the target cell plasma membrane. Internalized particles are trafficked to endosomes followed by endosomal release of the particles and/or the nucleic acid into cytoplasm. Released siRNA will form a RNA-induced silencing complex and will be guided for cleavage of complementary target mRNA in the cytoplasm. SiRNA (antisense) guide strand will direct the targeted RNAs to be cleaved by RNA endonuclease. Finally, plasmid/Tf-PEG-PEI-nanoparticles delivery in the target cell shows reporter gene expression and activity. The normal tissue cells are not affected because they do not make the targeted CD44 variant. Tf-PEG-PEI nanoparticle coated plasmids (pSico-CD44v6 shRNA/pFabpl-Cre) circulating in blood accumulate at tumor regions enhanced by the EPR effect. Endocytosis mediated by ligand-receptor interactions occurs because the nanoparticles are coated with the Tf-ligand for the Tf-R receptor on the tumor cell surface. 


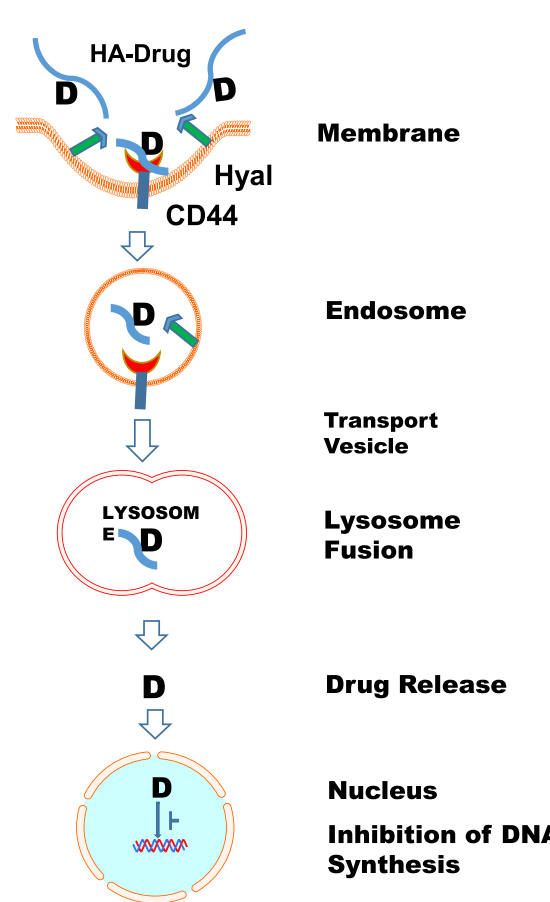

FIGURE 8 | Exploitation of HA-CD44 interaction for anticancer therapy. Left panel shows a schematic diagram for cancer cell internalization of HA conjugated to a drug inhibitor of DNA synthesis. CD44 on the membrane traps the HA-drug conjugate and efficiently internalizes it by endocytosis and forms an endosomal vesicle. This is then transported to the lysosome and fused, and the internalized $\mathrm{HA}$ is degraded by hyaluronidase 1 (Hyal-1) into small HA oligosaccharides and then to monosaccharides by lysosomal glycosidases, which ultimately releases the conjugated drug. The drug then goes to the nucleus and inhibits the DNA synthesis. Right panel shows targeting the CD44v6mRNA in cancer cells by
The tissue-specific shRNA delivery was made possible by the use of Cre-recombinase produced in response to a colon tissuespecific promoter, which deletes the interruption between the U6 promoter and the CD44v6 shRNA oligonucleotide. The newly developed cell-specific shRNA delivery approach by Misra et al. (94) confirmed that targeting the signaling pathways induced by HA-CD44v6 interaction inhibited distant colon tumor growth in Apc Min/+ mice. Our recent unpublished in vivo studies with the $\mathrm{C} 57 \mathrm{Bl} / 6$ mice have now shown that systemic delivery of a mixture of two plasmids, prostate-specific Probasin-Cre/Tf-PEGPEI-nanoparticles and floxed pSico-CD44v9shRNA/Tf-PEG-PEInanoparticles, can target both localized and metastatic prostate cancer cells. This novel approach opens up new ways to combat cancer and to understand tumorigenesis in vivo for the following reasons (Figure 7).

(i) Cell-specific shRNA to CD44variant (CD44vshRNA) is released by applying a tissue-specific promoter driven Crelox mechanism.

(ii) This shRNA silences the expression of the selected CD44 variant in the target tissue cancer cells.

(iii) This shRNA does not affect the normal target tissue cells, which rely on the standard CD44s and do not express the

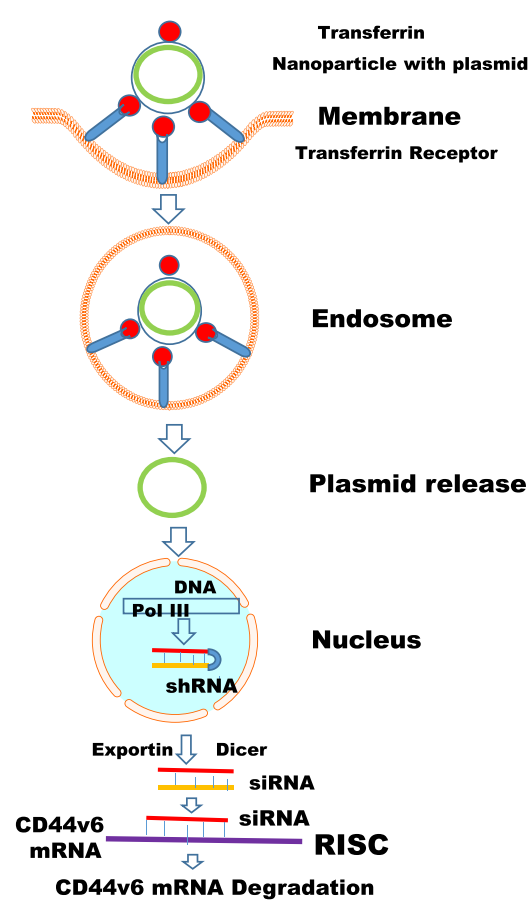

CD44v6 shRNA. Plasmids that produce CD44v6 shRNA are coated with transferrin present on the outer surface of the nanoparticles. The transferrin molecules then target the transferrin receptors present in high amounts on the cancer cells. Upon internalization, an endosome forms and the plasmids are released to the nucleus where CD44v6 shRNA is produced by DNA pol III. The shRNA is then exported out of the nucleus by exportin, and the dicer enzyme converts shRNA into CD44v6 siRNA. One of the strands of siRNA will bind to CD44v6 mRNA and form a RISC (RNA-induced silencing complex) that is ultimately degraded. Adapted from our article in the International Journal of Cell Biology. targeted CD44variant, and therefore are not affected by the plasmids.

(iv) The target CD44vshRNA will not be expressed in other types of cells because the tissue-specific promoter only unlocks the Cre-recombinase in the targeted tissue cells, which reduces potential side effects (94).

(v) The Tf-PEG-PEI-nanoparticles that carry plasmids are biodegradable and cleared from the system.

(vi) This method inhibits the pathophysiological role of HACD44v interactions in cancer.

(vii) It can establish diagnostic markers for the targeted cancer, including CD44variants, soluble CD44, and HA.

(viii) It can identify HA-CD44v interactions as innovative novel therapeutic targets against cancer progression.

Thus, the conditional suppression of gene expression by the use of a CD44vshRNA expressing plasmid holds potential promise for therapeutic approaches for silencing HA-CD44variant signaling and downstream signaling pathways that promote disease causing genes (386).

\section{Targeting RHAMM in Cancer}

Under homeostatic condition, RHAMM expression is very low. Its expression is increased during pathogenesis (inflammation and 
TABLE 4 | RHAMM function in cancer.

\begin{tabular}{llll}
\hline Disease model & Function of RHAMM in cancer & Approach using HA-binding peptide & Reference \\
\hline Esophageal squamous cell carcinoma & Invasiveness & Pep-1 & RHAMM-R3 peptides \\
Multiple myeloma and myelodysplasia syndrome & Anti-apoptosis & RHAMM silencing & (393) \\
Malignant peripheral nerve sheath tumors or multiple myeloma & Apoptotic resistance & RHAMM-based immunotherapies & (396-398) \\
Neuroblastoma tumors & Apoptotic resistance & targeting AURKA and BARD1 & (399, 400) \\
Acute myeloid leukemia & Antitumor activity & RHAMM R3 & (395, 401)
\end{tabular}

cancer) (132). Such a restricted expression of RHAMM makes it a suitable target for cancer and wound repair therapy with low toxicity (132).

\section{RHAMM-Based Immunotherapies}

Peptides that mimic either RHAMM itself or the HA sizes that bind to RHAMM have been shown to affect neoplastic processes as well as inflammation and wound repair (Table 4). HA targeting by Pep-1 blocked esophageal squamous cell carcinoma invasiveness by inhibiting HA-RHAMM induced effects (391). There is evidence that RHAMM-R3 peptides that are currently being tested in phase II clinical trials for multiple myeloma and myelodysplastic syndrome show efficacy and low toxicity in patients (392, 393). RHAMM silencing abrogated the self-renewing property of glioblastoma stem cells, and loss of RHAMM in malignant peripheral nerve sheath tumors or multiple myeloma sensitizes tumor cells to inhibitors (394-396). Neuroblastoma tumors are also sensitive to RHAMM-based immunotherapies due to the established roles of AURKA (397) and BARD1 [breast cancer gene 1 (BRCA1)-associated ring domain protein-1] (398), two components of the AURKA-BRCA1/BARD1-RHAMM-TPX2 centrosome module, within this refractory disease (267).

\section{Cell-Based Therapies}

In addition, cell-based strategies using peptide vaccination with a RHAMM-derived, highly immunogenic peptide, termed RHAMM R3, has proven safe and effective at generating CD8+ RHAMM-specific T cell cytotoxic cellular responses and antitumor activity in patients with AML, myelodysplastic syndrome, multiple myeloma, and, more recently, chronic lymphocytic leukemia in phase I/II trials $(393,399)$ (Table 4). These studies provide evidence that blocking RHAMM is a promising immunotherapy approach in patients with hematological malignancies. In another study, antitumor activity has also been reported for vaccination with dendritic cells expressing exogenous RHAMM mRNA in a mouse model of glioma (400).

A handful of RHAMM-based therapeutical studies in cancer suggest that more intense studies should be undertaken to determine how RHAMM signaling contributes to cancer progression. Although HA-receptor-mediated signaling is believed to be a promising anticancer/anti-inflammatory drug target, given the dual functions of HA, CD44 and RHAMM in the inflammatory/tumorigenic responses, caution must be taken in considering therapeutic targeting of these molecules, which should be designed for specific organs and specific diseases with consideration of the use of proper sizes of endotoxin free HA, which might provide a way to prevent side effects.

\section{Conclusion}

In the past few years, basic and clinical research on CD44 have identified the genomic DNA structure and alternative splicing pattern of CD44, which has led to a conclusion that CD44v is not one but a family of proteins, and that discrete isoforms are expressed and regulated at various stages of oncogenic transformation. Most, but not all, cancers overexpress discrete species of CD44v, which can be correlated with tumor aggressiveness. A challenging area of research would be to define what cellular functions are associated with the various CD44 isoforms that are overexpressed in various cancers before a CD44-based therapy can be undertaken. Considering the biological functions of HA particularly the connection of such function with molecular size of HA, the HA-binding proteins, its spatial and temporal distribution in tissues, and the cellular background and tissue stages, care must be taken to ensure the long-term safety of HA-based bioconjugates. Thus, this review defines the origins of evidence for a linkage between HA, CD44v, and RHAMM expression with inflammatory diseases, including malignancy, and emphasizes the most advanced and developed therapeutic strategies, those that have either been used for clinical trial or are nearly ready to get there. In addition, approaches used in various preclinical models are also briefly reviewed. Studies reviewed here identified strong prospects for anti-CD44 therapies. The HA-CD44 interaction system is illustrated in Figure 8 where we specify cancer therapeutical aspects (discussed in this review) that specifically perturb HACD44 signaling pathways. Interference with the function of HACD44 can inhibit the inflammation/malignant processes at multiple stages. This can be accomplished by perturbing HA-CD44 signaling pathways, by disruption of the HA matrix with HYALs to facilitate passive carrier uptake and providing a sustained source of drug at the tumor site, by targeting CD44 with a CD44-blocking antibody, or by tissue-specific targeting of specific variants of $\mathrm{CD} 44 \mathrm{v}$ that are overexpressed in tumors (Figure 8).

Although overexpression of CD44 correlates with bad prognosis in patients with most human cancers (151, 178-184), it was also found that CD44 is extremely sensitive to changes in the microenvironment. For example, CD44 in breast cancer cells, neuroblastomas and prostate cancer may act as a metastatic suppressor gene $(170,185,186)$, suggesting that the growth promoting pathways in these tumors are independent of CD44. These differential regulations should be considered carefully while designing CD44 as a target for therapeutic strategy.

For last two decades, several studies were dedicated to the use of CD44v, in particular CD44v6, as a therapeutic target. As discussed in Section "Targeting with Anti-CD44 Antibodies," the 
anti-CD44v6 antibody conjugated with mertansine showed dose limiting skin toxicity due to CD44v6 expression in non-tumor skin tissue. However, the scientific progress in the last few years provides strong support for using CD44v as a target for therapeutic strategies. This is due to the fact that: (1) CD44v6 is a marker for colon CSCs $(180,385)$; (2) CD44v6 can act as co-receptor for at least three RTKs (c-Met, VEGFR-2, and EGFR) $(103,236,401)$, and many of the oncogenic functions of CD44v6 can be attributed to downstream signaling induced by these RTKs; and (3) CD44v6 is highly expressed in many cancers. Nevertheless, there is an urgent need to define which CD44v variants are present on the CSCs for the particular type of cancer, and then target them in signaling complex tissue specifically by non-viral vectors. Collectively, these studies suggest that future development of drug targeting approaches can use tissue-specific expression of CD44v-specific antagonists as well as inhibitors (agents that are currently used in the clinic) targeting CD44 isoforms and their co-receptors/ligands that

\section{References}

1. Hanahan D, Weinberg RA. Hallmarks of cancer: the next generation. Cell (2011) 144:646-74. doi:10.1016/j.cell.2011.02.013

2. Christofori G. Changing neighbours, changing behaviour: cell adhesion molecule-mediated signalling during tumour progression. EMBO J (2003) 22:2318-23. doi:10.1093/emboj/cdg228

3. Bissell MJ. Modelling molecular mechanisms of breast cancer and invasion: lessons from the normal gland. Biochem Soc Trans (2007) 35:18-22. doi:10. 1042/BST0350018

4. Camenisch TD, Schroeder JA, Bradley J, Klewer SE, McDonald JA. Heart-valve mesenchyme formation is dependent on hyaluronan-augmented activation of ErbB2-ErbB3 receptors. Nat Med (2002) 8:850-5.

5. Camenisch TD, Spicer AP, Brehm-Gibson T, Biesterfeldt J, Augustine ML, Calabro A Jr, et al. Disruption of hyaluronan synthase-2 abrogates normal cardiac morphogenesis and hyaluronan-mediated transformation of epithelium to mesenchyme. J Clin Invest (2000) 106:349-60. doi:10.1172/ JCI10272

6. Misra S, Heldin P, Hascall VC, Karamanos NK, Skandalis SS, Markwald RR, et al. Hyaluronan-CD44 interactions as potential targets for cancer therapy. FEBS J (2011) 278:1429-43. doi:10.1111/j.1742-4658.2011.08071.x

7. Ghatak S, Hascall VC, Karamanos NK, Markwald RR, Misra S. Targeting the tumor microenvironment in cancer progression. In Karamanos N, editor. Extracellular Matrix: Pathobiology and Signaling. Berlin: DeGruyter (2012). p. $729-46$.

8. Meyer K, Palmer JW. The polysaccharide of the vitreous humor. J Biol Chem (1934) 107:629-34.

9. Olczyk P, Komosinska-Vassev K, Winsz-Szczotka K, Kuznik-Trocha K, Olczyk K. [Hyaluronan: structure, metabolism, functions, and role in wound healing]. Postepy Hig Med Dosw (Online) (2008) 62:651-9.

10. Gandhi NS, Mancera RL. The structure of glycosaminoglycans and their interactions with proteins. Chem Biol Drug Des (2008) 72:455-82. doi:10.1111/ j.1747-0285.2008.00741.x

11. Laurent TC, Fraser JR. Hyaluronan. FASEB J (1992) 6:2397-404.

12. Sohara Y, Ishiguro N, Machida K, Kurata H, Thant AA, Senga T, et al. Hyaluronan activates cell motility of $\mathrm{v}$-Src-transformed cells via Ras-mitogen-activated protein kinase and phosphoinositide 3-kinase-Akt in a tumor-specific manner. Mol Biol Cell (2001) 12:1859-68. doi:10.1091/mbc.12.6.1859

13. Collis L, Hall C, Lange L, Ziebell M, Prestwich R, Turley EA. Rapid hyaluronan uptake is associated with enhanced motility: implications for an intracellular mode of action. FEBS Lett (1998) 440:444-9. doi:10.1016/S0014-5793(98) 01505- 1

14. Underhill CB, Green SJ, Comoglio PM, Tarone G. The hyaluronate receptor is identical to a glycoprotein of $\mathrm{Mr} 85,000$ (gp85) as shown by a monoclonal antibody that interferes with binding activity. J Biol Chem (1987) 262:13142-6. alter intracellular signaling in the inflammatory/tumor tissue microenvironment, as an effective and novel approach to regulate these diseases. Finally, since CD44 and RHAMM bind to HA, targeting against RHAMM may be an additional treatment option.

\section{Author Contributions}

SG and SM wrote the review. Dr. VH has reviewed the draft and final version, and the revised draft of the manuscript. Dr. RM has edited the final and revised version of the manuscript.

\section{Acknowledgments}

This work was supported by 1R03CA167722-01A1 (to SM and SG); P20RR021949 (to SG), P20RR016434 (to SM, SG, and RM), P20RR16461-05 (to SG, and RM), RO1-HL033756-24, A1 PO1HL107147 (to VH), and EPS 0903795 (to SM).

15. Stamenkovic I, Amiot M, Pesando JM, Seed B. A lymphocyte molecule implicated in lymph node homing is a member of the cartilage link protein family Cell (1989) 56:1057-62. doi:10.1016/0092-8674(89)90638-7

16. Aruffo A, Stamenkovic I, Melnick M, Underhill CB, Seed B. CD44 is the principal cell surface receptor for hyaluronate. Cell (1990) 61:1303-13. doi:10 1016/0092-8674(90)90694-A

17. Lesley J, Schulte R, Hyman R. Binding of hyaluronic acid to lymphoid cell lines is inhibited by monoclonal antibodies against Pgp-1. Exp Cell Res (1990) 187:224-33. doi:10.1016/0014-4827(90)90085-O

18. Miyake K, Underhill CB, Lesley J, Kincade PW. Hyaluronate can function as a cell adhesion molecule and CD44 participates in hyaluronate recognition. J Exp Med (1990) 172:69-75. doi:10.1084/jem.172.1.69

19. Ghatak S, Hascall VC, Markwald RR, Misra S. Stromal hyaluronan interaction with epithelial CD44 variants promotes prostate cancer invasiveness by augmenting expression and function of hepatocyte growth factor and androgen receptor. J Biol Chem (2010) 285:19821-32. doi:10.1074/jbc.M110. 104273

20. Hardwick C, Hoare K, Owens R, Hohn HP, Hook M, Moore D, et al. Molecular cloning of a novel hyaluronan receptor that mediates tumor motility. J Cell Biol (1992) 117:1343-50.

21. Turley EA. Hyaluronan and cell locomotion. Cancer Metastasis Rev (1992) 11:21-30. doi:10.1007/BF00047600

22. Turley EA, Austen L, Vandeligt K, Clary C. Hyaluronan and a cell-associated hyaluronan binding protein regulate the locomotion of ras-transformed cells. J Cell Biol (1991) 112:1041-7. doi:10.1083/jcb.112.5.1041

23. Tammi MI, Day AJ, Turley EA. Hyaluronan and homeostasis: a balancing act J Biol Chem (2002) 277:4581-4. doi:10.1074/jbc.R100037200

24. Ponta H, Sherman L, Herrlich PA. CD44: from adhesion molecules to signalling regulators. Nat Rev Mol Cell Biol (2003) 4:33-45. doi:10.1038/nrm 1004

25. Naor D, Nedvetzki S, Golan I, Melnik L, Faitelson Y. CD44 in cancer. Crit Rev Clin Lab Sci (2002) 39:527-79. doi:10.1080/10408360290795574

26. Naor D, Sionov RV, Ish-Shalom D. CD44: structure, function, and association with the malignant process. Adv Cancer Res (1997) 71:241-319. doi:10.1016/ S0065-230X(08)60101-3

27. Toole BP. Hyaluronan in morphogenesis. Semin Cell Dev Biol (2001) 12:79-87. doi:10.1006/scdb.2000.0244

28. Turley EA, Noble PW, Bourguignon LY. Signaling properties of hyaluronan receptors. J Biol Chem (2002) 277:4589-92. doi:10.1074/jbc.R100038200

29. Zhang S, Chang MC, Zylka D, Turley S, Harrison R, Turley EA. The hyaluronan receptor RHAMM regulates extracellular-regulated kinase. J Biol Chem (1998) 273:11342-8. doi:10.1074/jbc.273.18.11342

30. Yang B, Yang BL, Savani RC, Turley EA. Identification of a common hyaluronan binding motif in the hyaluronan binding proteins RHAMM, CD44 and link protein. EMBO J (1994) 13:286-96.

31. Day TD. The permeability of interstitial connective tissue and the nature of the interfibrillary substance. J Physiol (1952) 117:1-8. 
32. Hascall VC, Laurent T. Hyaluronan: Structure and Physical Properties. (1997). Available from: www.glycoforum.gr.jp

33. Hascall VC, Majors AK, De La Motte CA, Evanko SP, Wang A, Drazba JA, et al. Intracellular hyaluronan: a new frontier for inflammation? Biochim Biophys Acta (2004) 1673:3-12. doi:10.1016/j.bbagen.2004.02.013

34. Spicer AP, Tien JY. Hyaluronan and morphogenesis. Birth Defects Res C Embryo Today (2004) 72:89-108. doi:10.1002/bdrc.20006

35. Heldin P, Pertoft H. Synthesis and assembly of the hyaluronan-containing coats around normal human mesothelial cells. Exp Cell Res (1993) 208:422-9. doi:10.1006/excr.1993.1264

36. Evanko SP, Parks WT, Wight TN. Intracellular hyaluronan in arterial smooth muscle cells: association with microtubules, RHAMM, and the mitotic spindle. J Histochem Cytochem (2004) 52:1525-35. doi:10.1369/jhc.4A6356.2004

37. Toole BP. Hyaluronan: from extracellular glue to pericellular cue. Nat Rev Cancer (2004) 4:528-39. doi:10.1038/nrc1391

38. Weigel PH, Hascall VC, Tammi M. Hyaluronan synthases. J Biol Chem (1997) 272:13997-4000. doi:10.1074/jbc.272.22.13997

39. Itano N. Simple primary structure, complex turnover regulation and multiple roles of hyaluronan. J Biochem (2008) 144:131-7. doi:10.1093/jb/mvn046

40. Itano N, Sawai T, Yoshida M, Lenas P, Yamada Y, Imagawa M, et al. Three isoforms of mammalian hyaluronan synthases have distinct enzymatic properties. J Biol Chem (1999) 274:25085-92. doi:10.1074/jbc.274.35.25085

41. Fraser JR, Laurent TC, Laurent UB. Hyaluronan: its nature, distribution, functions and turnover. J Intern Med (1997) 242:27-33. doi:10.1046/j.1365-2796. 1997.00170.x

42. Day AJ, Prestwich GD. Hyaluronan-binding proteins: tying up the giant. J Biol Chem (2002) 277:4585-8. doi:10.1074/jbc.R100036200

43. McBride WH, Bard JB. Hyaluronidase-sensitive halos around adherent cells. Their role in blocking lymphocyte-mediated cytolysis. J Exp Med (1979) 149:507-15. doi:10.1084/jem.149.2.507

44. Gately CL, Muul LM, Greenwood MA, Papazoglou S, Dick SJ, Kornblith $\mathrm{PL}$, et al. In vitro studies on the cell-mediated immune response to human brain tumors. II. Leukocyte-induced coats of glycosaminoglycan increase the resistance of glioma cells to cellular immune attack. J Immunol (1984) 133:3387-95.

45. Bastow ER, Byers S, Golub SB, Clarkin CE, Pitsillides AA, Fosang AJ. Hyaluronan synthesis and degradation in cartilage and bone. Cell Mol Life Sci (2008) 65:395-413. doi:10.1007/s00018-007-7360-z

46. Camenisch TD, McDonald JA. Hyaluronan: is bigger better? Am J Respir Cell Mol Biol (2000) 23:431-3. doi:10.1165/ajrcmb.23.4.f201

47. Ghatak S, Misra S, Norris RA, Moreno-Rodriguez RA, Hoffman S, Levine RA, et al. Periostin induces intracellular cross-talk between kinases and hyaluronan in atrioventricular valvulogenesis. J Biol Chem (2014) 289:8545-61. doi:10. 1074/jbc.M113.539882

48. Fox SB, Fawcett J, Jackson DG, Collins I, Gatter KC, Harris AL, et al. Normal human tissues, in addition to some tumors, express multiple different CD44 isoforms. Cancer Res (1994) 54:4539-46.

49. Hrabarova E, Juranek I, Soltes L. Pro-oxidative effect of peroxynitrite regarding biological systems: a special focus on high-molar-mass hyaluronan degradation. Gen Physiol Biophys (2011) 30:223-38. doi:10.4149/gpb_2011_03_223

50. Hrabarova E, Valachova K, Juranek I, Soltes L. Free-radical degradation of high-molar-mass hyaluronan induced by ascorbate plus cupric ions: evaluation of antioxidative effect of cysteine-derived compounds. Chem Biodivers (2012) 9:309-17. doi:10.1002/cbdv.201100046

51. Soltes L, Mendichi R, Kogan G, Schiller J, Stankovska M, Arnhold J. Degradative action of reactive oxygen species on hyaluronan. Biomacromolecules (2006) 7:659-68. doi:10.1021/bm050867v

52. Knudson W, Chow G, Knudson CB. CD44-mediated uptake and degradation of hyaluronan. Matrix Biol (2002) 21:15-23. doi:10.1016/S0945-053X(01) 00186-X

53. Jackson DG. Biology of the lymphatic marker LYVE-1 and applications in research into lymphatic trafficking and lymphangiogenesis. APMIS (2004) 112:526-38. doi:10.1111/j.1600-0463.2004.apm11207-0811.x

54. Stern R, Jedrzejas MJ. Hyaluronidases: their genomics, structures, and mechanisms of action. Chem Rev (2006) 106:818-39. doi:10.1021/cr050247k

55. Roden L, Campbell P, Fraser JR, Laurent TC, Pertoft H, Thompson JN. Enzymic pathways of hyaluronan catabolism. Ciba Found Symp (1989) 143:60-76.
56. Frost GI, Csoka TB, Wong T, Stern R. Purification, cloning, and expression of human plasma hyaluronidase. Biochem Biophys Res Commun (1997) 236:10-5. doi:10.1006/bbrc.1997.6773

57. Gmachl M, Sagan S, Ketter S, Kreil G. The human sperm protein PH20 has hyaluronidase activity. FEBS Lett (1993) 336:545-8. doi:10.1016/ 0014-5793(93)80873-S

58. Lepperdinger G, Strobl B, Kreil G. HYAL2, a human gene expressed in many cells, encodes a lysosomal hyaluronidase with a novel type of specificity. J Biol Chem (1998) 273:22466-70. doi:10.1074/jbc.273.35.22466

59. Lin Y, Mahan K, Lathrop WF, Myles DG, Primakoff P. A hyaluronidase activity of the sperm plasma membrane protein $\mathrm{PH}-20$ enables sperm to penetrate the cumulus cell layer surrounding the egg. J Cell Biol (1994) 125:1157-63. doi:10.1083/jcb.125.5.1157

60. Bookbinder LH, Hofer A, Haller MF, Zepeda ML, Keller GA, Lim JE, et al. A recombinant human enzyme for enhanced interstitial transport of therapeutics. J Control Release (2006) 114:230-41. doi:10.1016/j.jconrel.2006. 05.027

61. Provenzano PP, Cuevas C, Chang AE, Goel VK, Von Hoff DD, Hingorani SR. Enzymatic targeting of the stroma ablates physical barriers to treatment of pancreatic ductal adenocarcinoma. Cancer Cell (2012) 21:418-29. doi:10. 1016/j.ccr.2012.01.007

62. Stern R, Asari AA, Sugahara KN. Hyaluronan fragments: an information-rich system. Eur J Cell Biol (2006) 85:699-715. doi:10.1016/j.ejcb.2006.05.009

63. Gunthert U. CD44: a multitude of isoforms with diverse functions. Curr Top Microbiol Immunol (1993) 184:47-63.

64. Gunthert U, Hofmann M, Rudy W, Reber S, Zoller M, Haussmann I, et al. A new variant of glycoprotein CD44 confers metastatic potential to rat carcinoma cells. Cell (1991) 65:13-24. doi:10.1016/0092-8674(91) 90403-L

65. Naor D, Wallach-Dayan SB, Zahalka MA, Sionov RV. Involvement of CD44, a molecule with a thousand faces, in cancer dissemination. Semin Cancer Biol (2008) 18:260-7. doi:10.1016/j.semcancer.2008.03.015

66. Yamada Y, Itano N, Narimatsu H, Kudo T, Morozumi K, Hirohashi S, et al. Elevated transcript level of hyaluronan synthasel gene correlates with poor prognosis of human colon cancer. Clin Exp Metastasis (2004) 21:57-63. doi:10. 1023/B:CLIN.0000017203.71293.e0

67. Kosaki R, Watanabe K, Yamaguchi Y. Overproduction of hyaluronan by expression of the hyaluronan synthase Has2 enhances anchorage-independent growth and tumorigenicity. Cancer Res (1999) 59:1141-5.

68. Liu N, Gao F, Han Z, Xu X, Underhill CB, Zhang L. Hyaluronan synthase 3 overexpression promotes the growth of TSU prostate cancer cells. Cancer Res (2001) 61:5207-14.

69. Simpson MA, Wilson CM, McCarthy JB. Inhibition of prostate tumor cell hyaluronan synthesis impairs subcutaneous growth and vascularization in immunocompromised mice. Am J Pathol (2002) 161:849-57. doi:10.1016/ S0002-9440(10)64245-9

70. Hall CL, Wang C, Lange LA, Turley EA. Hyaluronan and the hyaluronan receptor RHAMM promote focal adhesion turnover and transient tyrosine kinase activity. J Cell Biol (1994) 126:575-88. doi:10.1083/jcb.126.2.575

71. Lokeshwar VB, Selzer MG. Differences in hyaluronic acid-mediated functions and signaling in arterial, microvessel, and vein-derived human endothelial cells. J Biol Chem (2000) 275:27641-9.

72. Tian X, Azpurua J, Hine C, Vaidya A, Myakishev-Rempel M, Ablaeva J, et al. High-molecular-mass hyaluronan mediates the cancer resistance of the naked mole rat. Nature (2013) 499:346-9. doi:10.1038/nature12234

73. Itano N, Sawai T, Atsumi F, Miyaishi O, Taniguchi S, Kannagi R, et al. Selective expression and functional characteristics of three mammalian hyaluronan synthases in oncogenic malignant transformation. J Biol Chem (2004) 279:18679-87. doi:10.1074/jbc.M313178200

74. Horton MR, Shapiro S, Bao C, Lowenstein CJ, Noble PW. Induction and regulation of macrophage metalloelastase by hyaluronan fragments in mouse macrophages. J Immunol (1999) 162:4171-6.

75. Noble PW, Lake FR, Henson PM, Riches DW. Hyaluronate activation of CD44 induces insulin-like growth factor-1 expression by a tumor necrosis factoralpha-dependent mechanism in murine macrophages. J Clin Invest (1993) 91:2368-77. doi:10.1172/JCI116469

76. Hodge-Dufour J, Noble PW, Horton MR, Bao C, Wysoka M, Burdick $\mathrm{MD}$, et al. Induction of IL-12 and chemokines by hyaluronan requires 
adhesion-dependent priming of resident but not elicited macrophages. $J$ Immunol (1997) 159:2492-500.

77. Beck-Schimmer B, Oertli B, Pasch T, Wuthrich RP. Hyaluronan induces monocyte chemoattractant protein-1 expression in renal tubular epithelial cells. J Am Soc Nephrol (1998) 9:2283-90.

78. Fitzgerald KA, Bowie AG, Skeffington BS, O’Neill LA. Ras, protein kinase C zeta, and I kappa B kinases 1 and 2 are downstream effectors of CD44 during the activation of NF-kappa B by hyaluronic acid fragments in T-24 carcinoma cells. J Immunol (2000) 164:2053-63. doi:10.4049/jimmunol.164.4.2053

79. Ohkawara Y, Tamura G, Iwasaki T, Tanaka A, Kikuchi T, Shirato K. Activation and transforming growth factor-beta production in eosinophils by hyaluronan. Am J Respir Cell Mol Biol (2000) 23:444-51. doi:10.1165/ajrcmb. 23.4.3875

80. West DC, Hampson IN, Arnold F, Kumar S. Angiogenesis induced by degradation products of hyaluronic acid. Science (1985) 228:1324-6. doi:10.1126/ science. 2408340

81. West DC, Kumar S. Hyaluronan and angiogenesis. Ciba Found Symp (1989) 143:187-201.

82. West DC, Kumar S. The effect of hyaluronate and its oligosaccharides on endothelial cell proliferation and monolayer integrity. Exp Cell Res (1989) 183:179-96. doi:10.1016/0014-4827(89)90428-X

83. Termeer CC, Hennies J, Voith U, Ahrens T, Weiss JM, Prehm P, et al. Oligosaccharides of hyaluronan are potent activators of dendritic cells. J Immunol (2000) 165:1863-70. doi:10.4049/jimmunol.165.4.1863

84. Pandey MS, Baggenstoss BA, Washburn J, Harris EN, Weigel PH. The hyaluronan receptor for endocytosis (HARE) activates NF-kappaB-mediated gene expression in response to $40-400-\mathrm{kDa}$, but not smaller or larger, hyaluronans. J Biol Chem (2013) 288:14068-79. doi:10.1074/jbc.M112.442889

85. Stern R. Devising a pathway for hyaluronan catabolism: are we there yet? Glycobiology (2003) 13:105R-15R. doi:10.1093/glycob/cwg112

86. Ghatak S, Misra S, Toole BP. Hyaluronan oligosaccharides inhibit anchorageindependent growth of tumor cells by suppressing the phosphoinositide 3kinase/Akt cell survival pathway. J Biol Chem (2002) 277:38013-20. doi:10. 1074/jbc.M202404200

87. Csoka TB, Frost GI, Stern R. Hyaluronidases in tissue invasion. Invasion Metastasis (1997) 17:297-311.

88. Uchiyama H, Dobashi Y, Ohkouchi K, Nagasawa K. Chemical change involved in the oxidative reductive depolymerization of hyaluronic acid. J Biol Chem (1990) 265:7753-9.

89. Entwistle J, Hall CL, Turley EA. HA receptors: regulators of signalling to the cytoskeleton. J Cell Biochem (1996) 61:569-77. doi:10.1002/(SICI) 1097-4644(19960616)61:4<569::AID-JCB10>3.0.CO;2-B

90. Weigel PH, Frost SJ, LeBoeuf RD, McGary CT. The specific interaction between fibrin(ogen) and hyaluronan: possible consequences in haemostasis, inflammation and wound healing. Ciba Found Symp (1989) 143:248-61.

91. Toole BP. Hyaluronan in morphogenesis. J Intern Med (1997) 242:35-40. doi:10.1046/j.1365-2796.1997.00171.x

92. Ghatak S, Bogatkevich GS, Atnelishvili I, Akter T, Feghali-Bostwick C, Hoffman S, et al. Overexpression of c-Met and CD44v6 receptors contributes to autocrine TGF-beta1 signaling in interstitial lung disease. J Biol Chem (2014) 289:7856-72. doi:10.1074/jbc.M113.505065

93. Misra S, Hascall VC, Berger FG, Markwald RR, Ghatak S. Hyaluronan, CD44, and cyclooxygenase-2 in colon cancer. Connect Tissue Res (2008) 49:219-24. doi: $10.1080 / 03008200802143356$

94. Misra S, Hascall VC, De Giovanni C, Markwald RR, Ghatak S. Delivery of CD44 shRNA/nanoparticles within cancer cells: perturbation of hyaluronan/CD44v6 interactions and reduction in adenoma growth in Apc Min/+ MICE. J Biol Chem (2009) 284:12432-46. doi:10.1074/jbc.M806772200

95. Misra S, Hascall VC, Karamanos NK, Markwald RR, Ghatak S. Delivery Systems Targeting Cancer at the Level of ECM. Berlin: DeGruyter (2012).

96. Misra S, Toole BP, Ghatak S. Hyaluronan constitutively regulates activation of multiple receptor tyrosine kinases in epithelial and carcinoma cells. J Biol Chem (2006) 281:34936-41. doi:10.1074/jbc.C600138200

97. Bourguignon LY, Peyrollier K, Xia W, Gilad E. Hyaluronan-CD44 interaction activates stem cell marker Nanog, Stat-3-mediated MDR1 gene expression, and ankyrin-regulated multidrug efflux in breast and ovarian tumor cells. $J$ Biol Chem (2008) 283:17635-51. doi:10.1074/jbc.M800109200

98. Bourguignon LY, Singleton PA, Zhu H, Diedrich F. Hyaluronan-mediated CD44 interaction with RhoGEF and Rho kinase promotes Grb2-associated binder-1 phosphorylation and phosphatidylinositol 3-kinase signaling leading to cytokine (macrophage-colony stimulating factor) production and breast tumor progression. J Biol Chem (2003) 278:29420-34. doi:10.1074/jbc. M301885200

99. Toole BP, Zoltan-Jones A, Misra S, Ghatak S. Hyaluronan: a critical component of epithelial-mesenchymal and epithelial-carcinoma transitions. Cells Tissues Organs (2005) 179:66-72. doi:10.1159/000084510

100. Pilarski LM, Masellis-Smith A, Belch AR, Yang B, Savani RC, Turley EA. RHAMM, a receptor for hyaluronan-mediated motility, on normal human lymphocytes, thymocytes and malignant B cells: a mediator in B cell malignancy? Leuk Lymphoma (1994) 14:363-74. doi:10.3109/10428199409049691

101. Scheibner KA, Lutz MA, Boodoo S, Fenton MJ, Powell JD, Horton MR. Hyaluronan fragments act as an endogenous danger signal by engaging TLR2. J Immunol (2006) 177:1272-81. doi:10.4049/jimmunol.177.2.1272

102. Jiang D, Liang J, Fan J, Yu S, Chen S, Luo Y, et al. Regulation of lung injury and repair by toll-like receptors and hyaluronan. Nat Med (2005) 11:1173-9. doi:10.1038/nm1315

103. Tremmel M, Matzke A, Albrecht I, Laib AM, Olaku V, Ballmer-Hofer K, et al. A CD44v6 peptide reveals a role of CD44 in VEGFR-2 signaling and angiogenesis. Blood (2009) 114:5236-44. doi:10.1182/blood-2009-04-219204

104. Zhuo L, Hascall VC, Kimata K. Inter-alpha-trypsin inhibitor, a covalent protein-glycosaminoglycan-protein complex. J Biol Chem (2004) 279:38079-82. doi:10.1074/jbc.R300039200

105. Day AJ, de la Motte CA. Hyaluronan cross-linking: a protective mechanism in inflammation? Trends Immunol (2005) 26:637-43. doi:10.1016/j.it. 2005.09.009

106. de la Motte CA, Hascall VC, Drazba J, Bandyopadhyay SK, Strong SA. Mononuclear leukocytes bind to specific hyaluronan structures on colon mucosal smooth muscle cells treated with polyinosinic acid:polycytidylic acid: inter-alpha-trypsin inhibitor is crucial to structure and function. Am J Pathol (2003) 163:121-33. doi:10.1016/S0002-9440(10)63636-X

107. Majors AK, Austin RC, de la Motte CA, Pyeritz RE, Hascall VC, Kessler $\mathrm{SP}$, et al. Endoplasmic reticulum stress induces hyaluronan deposition and leukocyte adhesion. J Biol Chem (2003) 278:47223-31. doi:10.1074/jbc. M304871200

108. Lesley J, Gal I, Mahoney DJ, Cordell MR, Rugg MS, Hyman R, et al. TSG-6 modulates the interaction between hyaluronan and cell surface CD44. J Biol Chem (2004) 279:25745-54. doi:10.1074/jbc.M313319200

109. de La Motte CA, Hascall VC, Calabro A, Yen-Lieberman B, Strong SA. Mononuclear leukocytes preferentially bind via CD44 to hyaluronan on human intestinal mucosal smooth muscle cells after virus infection or treatment with poly(I.C). J Biol Chem (1999) 274:30747-55. doi:10.1074/jbc.274. 43.30747

110. Lauer ME, Mukhopadhyay D, Fulop C, de la Motte CA, Majors AK, Hascall VC. Primary murine airway smooth muscle cells exposed to poly(I,C) or tunicamycin synthesize a leukocyte-adhesive hyaluronan matrix.J Biol Chem (2009) 284:5299-312. doi:10.1074/jbc.M807965200

111. Laurent TC, Laurent UB, Fraser JR. Functions of hyaluronan. Ann Rheum Dis (1995) 54:429-32. doi:10.1136/ard.54.5.429

112. McKee CM, Penno MB, Cowman M, Burdick MD, Strieter RM, Bao C, et al. Hyaluronan (HA) fragments induce chemokine gene expression in alveolar macrophages. The role of HA size and CD44. J Clin Invest (1996) 98:2403-13. doi:10.1172/JCI119054

113. Mascarenhas MM, Day RM, Ochoa CD, Choi WI, Yu L, Ouyang B, et al. Low molecular weight hyaluronan from stretched lung enhances interleukin8 expression. Am J Respir Cell Mol Biol (2004) 30:51-60. doi:10.1165/rcmb. 2002-0167OC

114. Powell JD, Horton MR. Threat matrix: low-molecular-weight hyaluronan (HA) as a danger signal. Immunol Res (2005) 31:207-18. doi:10.1385/IR:31 3:207

115. Boodoo S, Spannhake EW, Powell JD, Horton MR. Differential regulation of hyaluronan-induced IL-8 and IP-10 in airway epithelial cells. Am J Physiol Lung Cell Mol Physiol (2006) 291:L479-86. doi:10.1152/ajplung.00518.2005

116. McKee CM, Lowenstein CJ, Horton MR, Wu J, Bao C, Chin BY, et al. Hyaluronan fragments induce nitric-oxide synthase in murine macrophages through a nuclear factor kappaB-dependent mechanism. J Biol Chem (1997) 272:8013-8. doi:10.1074/jbc.272.12.8013

117. Horton MR, McKee CM, Bao C, Liao F, Farber JM, Hodge-DuFour J, et al. Hyaluronan fragments synergize with interferon-gamma to induce the C-X-C 
chemokines mig and interferon-inducible protein-10 in mouse macrophages. J Biol Chem (1998) 273:35088-94. doi:10.1074/jbc.273.52.35088

118. Horton MR, Olman MA, Bao C, White KE, Choi AM, Chin BY, et al. Regulation of plasminogen activator inhibitor- 1 and urokinase by hyaluronan fragments in mouse macrophages. Am J Physiol Lung Cell Mol Physiol (2000) 279:L707-15.

119. Casalino-Matsuda SM, Monzon ME, Conner GE, Salathe M, Forteza RM. Role of hyaluronan and reactive oxygen species in tissue kallikrein-mediated epidermal growth factor receptor activation in human airways. J Biol Chem (2004) 279:21606-16. doi:10.1074/jbc.M309950200

120. Bissell MJ, Radisky DC, Rizki A, Weaver VM, Petersen OW. The organizing principle: microenvironmental influences in the normal and malignant breast. Differentiation (2002) 70:537-46. doi:10.1046/j.1432-0436.2002.700907.x

121. Turley EA, Tretiak M. Glycosaminoglycan production by murine melanoma variants in vivo and in vitro. Cancer Res (1985) 45:5098-105.

122. Knudson W, Biswas C, Toole BP. Stimulation of glycosaminoglycan production in murine tumors. J Cell Biochem (1984) 25:183-96. doi:10.1002/jcb. 240250402

123. Knudson W, Biswas C, Toole BP. Interactions between human tumor cells and fibroblasts stimulate hyaluronate synthesis. Proc Natl Acad Sci U S A (1984) 81:6767-71. doi:10.1073/pnas.81.21.6767

124. Zhang L, Underhill CB, Chen L. Hyaluronan on the surface of tumor cells is correlated with metastatic behavior. Cancer Res (1995) 55:428-33.

125. Heldin P, Basu K, Olofsson B, Porsch H, Kozlova I, Kahata K. Deregulation of hyaluronan synthesis, degradation and binding promotes breast cancer. J Biochem (2013) 154:395-408. doi:10.1093/jb/mvt085

126. Itano N, Zhuo L, Kimata K. Impact of the hyaluronan-rich tumor microenvironment on cancer initiation and progression. Cancer Sci (2008) 99:1720-5. doi:10.1111/j.1349-7006.2008.00885.x

127. Zhu H, Mitsuhashi N, Klein A, Barsky LW, Weinberg K, Barr ML, et al. The role of the hyaluronan receptor CD44 in mesenchymal stem cell migration in the extracellular matrix. Stem Cells (2006) 24:928-35. doi:10.1634/stemcells. 2005-0186

128. DeAngelis PL. Glycosaminoglycan polysaccharide biosynthesis and production: today and tomorrow. Appl Microbiol Biotechnol (2012) 94:295-305. doi:10.1007/s00253-011-3801-6

129. Vigetti D, Viola M, Karousou E, De Luca G, Passi A. Metabolic control of hyaluronan synthases. Matrix Biol (2014) 35:8-13. doi:10.1016/j.matbio.2013. 10.002

130. Weigel PH, DeAngelis PL. Hyaluronan synthases: a decade-plus of novel glycosyltransferases. J Biol Chem (2007) 282:36777-81. doi:10.1074/jbc. R700036200

131. Itano N, Kimata K. Mammalian hyaluronan synthases. IUBMB Life (2002) 54:195-9. doi:10.1080/15216540214929

132. Tolg C, McCarthy JB, Yazdani A, Turley EA. Hyaluronan and RHAMM in wound repair and the "cancerization" of stromal tissues. Biomed Res Int (2014) 2014:103923. doi:10.1155/2014/103923

133. Karvinen S, Pasonen-Seppanen S, Hyttinen JM, Pienimaki JP, Torronen $\mathrm{K}$, Jokela TA, et al. Keratinocyte growth factor stimulates migration and hyaluronan synthesis in the epidermis by activation of keratinocyte hyaluronan synthases 2 and 3. J Biol Chem (2003) 278:49495-504. doi:10.1074/jbc. M310445200

134. Yung S, Thomas GJ, Davies M. Induction of hyaluronan metabolism after mechanical injury of human peritoneal mesothelial cells in vitro. Kidney Int (2000) 58:1953-62. doi:10.1111/j.1523-1755.2000.00367.x

135. Jacobson A, Brinck J, Briskin MJ, Spicer AP, Heldin P. Expression of human hyaluronan synthases in response to external stimuli. Biochem J (2000) 348(Pt 1):29-35. doi:10.1042/0264-6021:3480029

136. Heldin P, Karousou E, Bernert B, Porsch H, Nishitsuka K, Skandalis SS. Importance of hyaluronan-CD44 interactions in inflammation and tumorigenesis. Connect Tissue Res (2008) 49:215-8. doi:10.1080/03008200802143323

137. Itano N, Atsumi F, Sawai T, Yamada Y, Miyaishi O, Senga T, et al. Abnormal accumulation of hyaluronan matrix diminishes contact inhibition of cell growth and promotes cell migration. Proc Natl Acad Sci U S A (2002) 99:3609-14. doi:10.1073/pnas.052026799

138. Jacobetz MA, Chan DS, Neesse A, Bapiro TE, Cook N, Frese KK, et al. Hyaluronan impairs vascular function and drug delivery in a mouse model of pancreatic cancer. Gut (2013) 62:112-20. doi:10.1136/ gutjnl-2012-302529
139. Stamenkovic I, Aruffo A, Amiot M, Seed B. The hematopoietic and epithelial forms of CD44 are distinct polypeptides with different adhesion potentials for hyaluronate-bearing cells. EMBO J (1991) 10:343-8.

140. Lesley J, Hyman R. CD44 can be activated to function as an hyaluronic acid receptor in normal murine T cells. Eur I Immunol (1992) 22:2719-23. doi:10. 1002/eji.1830221036

141. St Jacques S, Dadi HK, Letarte M. CD44 in human placenta: localization and binding to hyaluronic acid. Placenta (1993) 14:25-39. doi:10.1016/ S0143-4004(05)80246-2

142. Peach RJ, Hollenbaugh D, Stamenkovic I, Aruffo A. Identification of hyaluronic acid binding sites in the extracellular domain of CD44. J Cell Biol (1993) 122:257-64. doi:10.1083/jcb.122.1.257

143. Lesley J, Hyman R, English N, Catterall JB, Turner GA. CD44 in inflammation and metastasis. Glycoconj J (1997) 14:611-22. doi:10.1023/A:1018540610858

144. Idzerda RL, Carter WG, Nottenburg C, Wayner EA, Gallatin WM, St John T. Isolation and DNA sequence of a cDNA clone encoding a lymphocyte adhesion receptor for high endothelium. Proc Natl Acad Sci U S A (1989) 86:4659-63. doi:10.1073/pnas.86.12.4659

145. Liao HX, Lee DM, Levesque MC, Haynes BF. N-terminal and central regions of the human CD44 extracellular domain participate in cell surface hyaluronan binding. J Immunol (1995) 155:3938-45.

146. Pure E, Camp RL, Peritt D, Panettieri RA Jr, Lazaar AL, Nayak S. Defective phosphorylation and hyaluronate binding of CD44 with point mutations in the cytoplasmic domain. J Exp Med (1995) 181:55-62. doi:10.1084/ jem.181.1.55

147. Bajorath J, Greenfield B, Munro SB, Day AJ, Aruffo A. Identification of CD44 residues important for hyaluronan binding and delineation of the binding site. J Biol Chem (1998) 273:338-43. doi:10.1074/jbc.273.1.338

148. Hofmann M, Rudy W, Zoller M, Tolg C, Ponta H, Herrlich P, et al. CD44 splice variants confer metastatic behavior in rats: homologous sequences are expressed in human tumor cell lines. Cancer Res (1991) 51:5292-7.

149. Zoller M. CD44: can a cancer-initiating cell profit from an abundantly expressed molecule? Nat Rev Cancer (2011) 11:254-67. doi:10.1038/nrc3023

150. Heider KH, Hofmann M, Hors E, van den Berg F, Ponta H, Herrlich P, et al. A human homologue of the rat metastasis-associated variant of CD44 is expressed in colorectal carcinomas and adenomatous polyps. J Cell Biol (1993) 120:227-33. doi:10.1083/jcb.120.1.227

151. Heider KH, Kuthan H, Stehle G, Munzert G. CD44v6: a target for antibodybased cancer therapy. Cancer Immunol Immunother (2004) 53:567-79. doi:10. 1007/s00262-003-0494-4

152. Tanabe KK, Ellis LM, Saya H. Expression of CD44R1 adhesion molecule in colon carcinomas and metastases. Lancet (1993) 341:725-6. doi:10.1016/ 0140-6736(93)90490-8

153. Wielenga VJ, Heider KH, Offerhaus GJ, Adolf GR, van den Berg FM, Ponta H, et al. Expression of CD44 variant proteins in human colorectal cancer is related to tumor progression. Cancer Res (1993) 53:4754-6.

154. Matsumura Y, Tarin D. Significance of CD44 gene products for cancer diagnosis and disease evaluation. Lancet (1992) 340:1053-8. doi:10.1016/ 0140-6736(92) $93077-\mathrm{Z}$

155. Koopman G, Heider KH, Horst E, Adolf GR, van den Berg F, Ponta H, et al. Activated human lymphocytes and aggressive non-Hodgkin's lymphomas express a homologue of the rat metastasis-associated variant of CD44. J Exp Med (1993) 177:897-904. doi:10.1084/jem.177.4.897

156. Heider KH, Dammrich J, Skroch-Angel P, Muller-Hermelink HK, Vollmers HP, Herrlich P, et al. Differential expression of CD44 splice variants in intestinal- and diffuse-type human gastric carcinomas and normal gastric mucosa. Cancer Res (1993) 53:4197-203.

157. Birch M, Mitchell S, Hart IR. Isolation and characterization of human melanoma cell variants expressing high and low levels of CD44. Cancer Res (1991) 51:6660-7.

158. Haynes BF, Liao HX, Patton KL. The transmembrane hyaluronate receptor (CD44): multiple functions, multiple forms. Cancer Cells (1991) 3:347-50.

159. Lesley J, Hyman R, Kincade PW. CD44 and its interaction with extracellular matrix. Adv Immunol (1993) 54:271-335. doi:10.1016/S0065-2776(08) 60537-4

160. van der Voort R, Taher TE, Wielenga VJ, Spaargaren M, Prevo R, Smit L, et al. Heparan sulfate-modified CD44 promotes hepatocyte growth factor/scatter factor-induced signal transduction through the receptor tyrosine kinase c-Met. J Biol Chem (1999) 274:6499-506. doi:10.1074/jbc.274.10.6499 
161. Skelton TP, Zeng C, Nocks A, Stamenkovic I. Glycosylation provides both stimulatory and inhibitory effects on cell surface and soluble CD44 binding to hyaluronan. J Cell Biol (1998) 140:431-46. doi:10.1083/jcb.140.2. 431

162. English NM, Lesley JF, Hyman R. Site-specific de-N-glycosylation of CD44 can activate hyaluronan binding, and CD44 activation states show distinct threshold densities for hyaluronan binding. Cancer Res (1998) 58:3736-42.

163. Ruffell B, Johnson P. Chondroitin sulfate addition to $\mathrm{CD} 44 \mathrm{H}$ negatively regulates hyaluronan binding. Biochem Biophys Res Commun (2005) 334:306-12. doi:10.1016/j.bbrc.2005.06.108

164. Lesley J, Howes N, Perschl A, Hyman R. Hyaluronan binding function of CD44 is transiently activated on T cells during an in vivo immune response. J Exp Med (1994) 180:383-7. doi:10.1084/jem.180.1.383

165. Yu Q, Stamenkovic I. Localization of matrix metalloproteinase 9 to the cell surface provides a mechanism for CD44-mediated tumor invasion. Genes Dev (1999) 13:35-48. doi:10.1101/gad.13.1.35

166. Yu Q, Stamenkovic I. Cell surface-localized matrix metalloproteinase-9 proteolytically activates TGF-beta and promotes tumor invasion and angiogenesis. Genes Dev (2000) 14:163-76.

167. Okamoto I, Tsuiki H, Kenyon LC, Godwin AK, Emlet DR, Holgado-Madruga $\mathrm{M}$, et al. Proteolytic cleavage of the CD44 adhesion molecule in multiple human tumors. Am J Pathol (2002) 160:441-7. doi:10.1016/S0002-9440(10) 64863-8

168. Okamoto I, Kawano Y, Murakami D, Sasayama T, Araki N, Miki T, et al. Proteolytic release of CD44 intracellular domain and its role in the CD44 signaling pathway. J Cell Biol (2001) 155:755-62. doi:10.1083/jcb.200108159

169. Cichy J, Pure E. The liberation of CD44. J Cell Biol (2003) 161:839-43. doi:10. 1083/jcb.200302098

170. Echiburu-Chau C, Roy D, Calaf GM. Metastatic suppressor CD44 is related with oxidative stress in breast cancer cell lines. Int J Oncol (2011) 39:1481-9. doi:10.3892/ijo.2011.1154

171. Stoop R, Kotani H, McNeish JD, Otterness IG, Mikecz K. Increased resistance to collagen-induced arthritis in CD44-deficient DBA/1 mice. Arthritis Rheum (2001) 44:2922-31. doi:10.1002/1529-0131(200112)44:12<2922:: AID-ART480>3.0.CO;2-7

172. Louderbough JM, Brown JA, Nagle RB, Schroeder JA. CD44 promotes epithelial mammary gland development and exhibits altered localization during cancer progression. Genes Cancer (2011) 2:771-81. doi:10.1177/ 1947601911428223

173. Louderbough JM, Schroeder JA. Understanding the dual nature of CD44 in breast cancer progression. Mol Cancer Res (2011) 9:1573-86. doi:10.1158/ 1541-7786.MCR-11-0156

174. Wang Q, Teder P, Judd NP, Noble PW, Doerschuk CM. CD44 deficiency leads to enhanced neutrophil migration and lung injury in Escherichia coli pneumonia in mice. Am J Pathol (2002) 161:2219-28. doi:10.1016/S0002-9440(10) 64498-7

175. Ruiz P, Schwarzler C, Gunthert U. CD44 isoforms during differentiation and development. Bioessays (1995) 17:17-24. doi:10.1002/bies.950170106

176. Kim H, Yang XL, Rosada C, Hamilton SR, August JT. CD44 expression in colorectal adenomas is an early event occurring prior to K-ras and p53 gene mutation. Arch Biochem Biophys (1994) 310:504-7. doi:10.1006/abbi.1994. 1199

177. Wielenga VJ, Smits R, Korinek V, Smit L, Kielman M, Fodde R, et al. Expression of CD44 in Apc and Tcf mutant mice implies regulation by the WNT pathway. Am J Pathol (1999) 154:515-23. doi:10.1016/S0002-9440(10)65297-2

178. Zeilstra J, Joosten SP, van Andel H, Tolg C, Berns A, Snoek M, et al. Stem cell $\mathrm{CD} 44 \mathrm{v}$ isoforms promote intestinal cancer formation in $\mathrm{Apc}(\mathrm{min})$ mice downstream of Wnt signaling. Oncogene (2014) 33:665-70. doi:10.1038/onc. 2012.611

179. Stauder R, Eisterer W, Thaler J, Gunthert U. CD44 variant isoforms in nonHodgkin's lymphoma: a new independent prognostic factor. Blood (1995) 85:2885-99.

180. Todaro M, Alea MP, Di Stefano AB, Cammareri P, Vermeulen L, Iovino F, et al. Colon cancer stem cells dictate tumor growth and resist cell death by production of interleukin-4. Cell Stem Cell (2007) 1:389-402. doi:10.1016/j. stem.2007.08.001

181. Guo W, Frenette PS. Alternative CD44 splicing in intestinal stem cells and tumorigenesis. Oncogene (2014) 33:537-8. doi:10.1038/onc.2013.260
182. Kainz C, Kohlberger P, Sliutz G, Tempfer C, Heinzl H, Reinthaller A, et al. Splice variants of CD44 in human cervical cancer stage IB to IIB. Gynecol Oncol (1995) 57:383-7. doi:10.1006/gyno.1995.1159

183. Kainz C, Kohlberger P, Tempfer C, Sliutz G, Gitsch G, Reinthaller A, et al. Prognostic value of CD44 splice variants in human stage III cervical cancer. Eur J Cancer (1995) 31 A:1706-9. doi:10.1016/0959-8049(95)00353-K

184. Hsieh HF, Yu JC, Ho LI, Chiu SC, Harn HJ. Molecular studies into the role of CD44 variants in metastasis in gastric cancer. Mol Pathol (1999) 52:25-8. doi:10.1136/mp.52.1.25

185. Shtivelman E, Bishop JM. Expression of CD44 is repressed in neuroblastoma cells. Mol Cell Biol (1991) 11:5446-53.

186. De Marzo AM, Bradshaw C, Sauvageot J, Epstein JI, Miller GJ. CD44 and CD44v6 downregulation in clinical prostatic carcinoma: relation to gleason grade and cytoarchitecture. Prostate (1998) 34:162-8. doi:10.1002/(SICI) 1097-0045(19980215)34:3<162::AID-PROS2>3.0.CO;2-K

187. Seiter S, Arch R, Reber S, Komitowski D, Hofmann M, Ponta H, et al. Prevention of tumor metastasis formation by anti-variant CD44. J Exp Med (1993) 177:443-55. doi:10.1084/jem.177.2.443

188. Misra S, Obeid LM, Hannun YA, Minamisawa S, Berger FG, Markwald RR, et al. Hyaluronan constitutively regulates activation of COX-2-mediated cell survival activity in intestinal epithelial and colon carcinoma cells. J Biol Chem (2008) 283:14335-44. doi:10.1074/jbc.M703811200

189. Pure E, Cuff CA. A crucial role for CD44 in inflammation. Trends Mol Med (2001) 7:213-21. doi:10.1016/S1471-4914(01)01963-3

190. Ruffell B, Johnson P. The Regulation and Function of Hyaluronan Binding by CD44 in the Immune System. Glycoforum: Science of Hyaluronan Today (2009). Available from: http://www.glycoforum.gr.jp/science/ hyaluronan/hyaluronanE.html

191. Siegelman MH, DeGrendele HC, Estess P. Activation and interaction of CD44 and hyaluronan in immunological systems. J Leukoc Biol (1999) 66:315-21.

192. Naor D, Nedvetzki S, Walmsley M, Yayon A, Turley EA, Golan I, et al. CD44 involvement in autoimmune inflammations: the lesson to be learned from CD44-targeting by antibody or from knockout mice. Ann N Y Acad Sci (2007) 1110:233-47. doi:10.1196/annals.1423.025

193. Nedvetzki S, Gonen E, Assayag N, Reich R, Williams RO, Thurmond RL, et al. RHAMM, a receptor for hyaluronan-mediated motility, compensates for CD44 in inflamed CD44-knockout mice: a different interpretation of redundancy. Proc Natl Acad Sci U S A (2004) 101:18081-6. doi:10.1073/pnas. 0407378102

194. DeGrendele HC, Estess P, Siegelman MH. Requirement for CD44 in activated $\mathrm{T}$ cell extravasation into an inflammatory site. Science (1997) 278:672-5. doi:10.1126/science.278.5338.672

195. DeGrendele HC, Estess P, Picker LJ, Siegelman MH. CD44 and its ligand hyaluronate mediate rolling under physiologic flow: a novel lymphocyteendothelial cell primary adhesion pathway. J Exp Med (1996) 183:1119-30. doi:10.1084/jem.183.3.1119

196. Clark RA, Alon R, Springer TA. CD44 and hyaluronan-dependent rolling interactions of lymphocytes on tonsillar stroma. J Cell Biol (1996) 134:1075-87. doi:10.1083/jcb.134.4.1075

197. Hutas G, Bajnok E, Gal I, Finnegan A, Glant TT, Mikecz K. CD44-specific antibody treatment and CD44 deficiency exert distinct effects on leukocyte recruitment in experimental arthritis. Blood (2008) 112:4999-5006. doi:10. 1182/blood-2008-04-150383

198. Khan AI, Kerfoot SM, Heit B, Liu L, Andonegui G, Ruffell B, et al. Role of CD44 and hyaluronan in neutrophil recruitment. J Immunol (2004) 173:7594-601. doi:10.4049/jimmunol.173.12.7594

199. McDonald B, McAvoy EF, Lam F, Gill V, de la Motte C, Savani RC, et al. Interaction of CD44 and hyaluronan is the dominant mechanism for neutrophil sequestration in inflamed liver sinusoids. J Exp Med (2008) 205:915-27. doi:10. 1084/jem.20071765

200. Cuff CA, Kothapalli D, Azonobi I, Chun S, Zhang Y, Belkin R, et al. The adhesion receptor $\mathrm{CD} 44$ promotes atherosclerosis by mediating inflammatory cell recruitment and vascular cell activation. J Clin Invest (2001) 108:1031-40. doi:10.1172/JCI200112455

201. Wang X, Xu L, Wang H, Zhan Y, Pure E, Feuerstein GZ. CD44 deficiency in mice protects brain from cerebral ischemia injury. J Neurochem (2002) 83:1172-9. doi:10.1046/j.1471-4159.2002.01225.x

202. Huebener P, Abou-Khamis T, Zymek P, Bujak M, Ying X, Chatila K, et al. CD44 is critically involved in infarct healing by regulating the inflammatory 
and fibrotic response. J Immunol (2008) 180:2625-33. doi:10.4049/jimmunol. 180.4.2625

203. Mikecz K, Brennan FR, Kim JH, Glant TT. Anti-CD44 treatment abrogates tissue oedema and leukocyte infiltration in murine arthritis. Nat Med (1995) 1:558-63. doi:10.1038/nm0695-558

204. Verdrengh M, Holmdahl R, Tarkowski A. Administration of antibodies to hyaluronanreceptor (CD44) delays the start and ameliorates the severity of collagen II arthritis. Scand J Immunol (1995) 42:353-8. doi:10.1111/j.1365-3083. 1995.tb03667.x

205. Zeidler A, Brauer R, Thoss K, Bahnsen J, Heinrichs V, Jablonski-Westrich D, et al. Therapeutic effects of antibodies against adhesion molecules in murine collagen type II-induced arthritis. Autoimmunity (1995) 21:245-52. doi:10. 3109/08916939509001943

206. Weiss L, Slavin S, Reich S, Cohen P, Shuster S, Stern R, et al. Induction of resistance to diabetes in non-obese diabetic mice by targeting CD44 with a specific monoclonal antibody. Proc Natl Acad Sci U S A (2000) 97:285-90. doi:10.1073/pnas.97.1.285

207. Stoop R, Gal I, Glant TT, McNeish JD, Mikecz K. Trafficking of CD44deficient murine lymphocytes under normal and inflammatory conditions. Eur J Immunol (2002) 32:2532-42. doi:10.1002/1521-4141(200209)32: 9<2532::AID-IMMU2532>3.0.CO;2-A

208. Kittl EM, Haberhauer G, Ruckser R, Selleny S, Rech-Weichselbraun I, Hinterberger W, et al. Serum levels of soluble CD44 variant isoforms are elevated in rheumatoid arthritis. Rheumatol Int (1997) 16:181-6. doi:10.1007/ BF01330293

209. Haberhauer G, Kittl EM. Soluble CD44 isoform variant-5 (sCD44v5): a new serum marker in rheumatoid arthritis? J Rheumatol (1998) 25:1442-4.

210. Wittig BM, Johansson B, Zoller M, Schwarzler C, Gunthert U. Abrogation of experimental colitis correlates with increased apoptosis in mice deficient for CD44 variant exon 7 (CD44v7). J Exp Med (2000) 191:2053-64. doi:10.1084/ jem.191.12.2053

211. Wittig BM, Stallmach A, Zeitz M, Gunthert U. Functional involvement of CD44 variant 7 in gut immune response. Pathobiology (2002) 70:184-9. doi:10. $1159 / 000068152$

212. Camacho FI, Munoz C, Sanchez-Verde L, Saez AI, Alcantara M, Rodriguez R. CD44v6 expression in inflammatory bowel disease is associated with activity detected by endoscopy and pathological features. Histopathology (1999) 35:144-9. doi:10.1046/j.1365-2559.1999.00712.x

213. Ikehata A, Tomichi N. CD44v6 expression in granuloma of Crohn's disease. Am J Gastroenterol (2000) 95:3325-6. doi:10.1111/j.1572-0241.2000.03324.x

214. Wittig B, Seiter S, Schmidt DS, Zuber M, Neurath M, Zoller M. CD44 variant isoforms on blood leukocytes in chronic inflammatory bowel disease and other systemic autoimmune diseases. Lab Invest (1999) 79:747-59.

215. Teder P, Vandivier RW, Jiang D, Liang J, Cohn L, Pure E, et al. Resolution of lung inflammation by CD44. Science (2002) 296:155-8. doi:10.1126/science. 1069659

216. Acharya PS, Majumdar S, Jacob M, Hayden J, Mrass P, Weninger W, et al. Fibroblast migration is mediated by CD44-dependent TGF beta activation. J Cell Sci (2008) 121:1393-402. doi:10.1242/jcs.021683

217. Toole BP, Ghatak S, Misra S. Hyaluronan oligosaccharides as a potential anticancer therapeutic. Curr Pharm Biotechnol (2008) 9:249-52. doi:10.2174/ 138920108785161569

218. Obayashi Y, Yabushita H, Kanyama K, Noguchi M, Zhuo L, Kimata K, et al. Role of serum-derived hyaluronan-associated protein-hyaluronan complex in ovarian cancer. Oncol Rep (2008) 19:1245-51.

219. Lesley J, English N, Charles C, Hyman R. The role of the CD44 cytoplasmic and transmembrane domains in constitutive and inducible hyaluronan binding. Eur J Immunol (2000) 30:245-53. doi:10.1002/1521-4141(200001)30:1<245:: AID-IMMU245>3.0.CO;2- $\mathrm{X}$

220. Lesley J, Hascall VC, Tammi M, Hyman R. Hyaluronan binding by cell surface CD44. J Biol Chem (2000) 275:26967-75.

221. Orian-Rousseau V, Sleeman J. CD44 is a multidomain signaling platform that integrates extracellular matrix cues with growth factor and cytokine signals. Adv Cancer Res (2014) 123:231-54. doi:10.1016/B978-0-12-800092-2. 00009-5

222. Lundell BI, McCarthy JB, Kovach NL, Verfaillie CM. Activation of beta1 integrins on CML progenitors reveals cooperation between betal integrins and CD44 in the regulation of adhesion and proliferation. Leukemia (1997) 11:822-9. doi:10.1038/sj.leu.2400653
223. Avigdor A, Goichberg P, Shivtiel S, Dar A, Peled A, Samira S, et al. CD44 and hyaluronic acid cooperate with SDF-1 in the trafficking of human CD34+ stem/progenitor cells to bone marrow. Blood (2004) 103:2981-9. doi:10.1182/ blood-2003-10-3611

224. Zohar R, Suzuki N, Suzuki K, Arora P, Glogauer M, McCulloch CA, et al. Intracellular osteopontin is an integral component of the CD44-ERM complex involved in cell migration. J Cell Physiol (2000) 184:118-30. doi:10.1002/(SICI) 1097-4652(200007)184:1<118::AID-JCP13>3.3.CO;2-P

225. Okamoto I, Kawano Y, Tsuiki H, Sasaki J, Nakao M, Matsumoto M, et al. CD44 cleavage induced by a membrane-associated metalloprotease plays a critical role in tumor cell migration. Oncogene (1999) 18:1435-46. doi:10.1038/sj.onc. 1202447

226. Culty M, Nguyen HA, Underhill CB. The hyaluronan receptor (CD44) participates in the uptake and degradation of hyaluronan. J Cell Biol (1992) 116:1055-62. doi:10.1083/jcb.116.4.1055

227. Gschwind A, Fischer OM, Ullrich A. The discovery of receptor tyrosine kinases: targets for cancer therapy. Nat Rev Cancer (2004) 4:361-70. doi:10. 1038/nrc1360

228. Misra S, Ghatak S, Toole BP. Regulation of MDR1 expression and drug resistance by a positive feedback loop involving hyaluronan, phosphoinositide 3-kinase, and ErbB2. J Biol Chem (2005) 280:20310-5. doi:10.1074/jbc. M500737200

229. Ghatak S, Misra S, Toole BP. Hyaluronan constitutively regulates ErbB2 phosphorylation and signaling complex formation in carcinoma cells. J Biol Chem (2005) 280:8875-83. doi:10.1074/jbc.M410882200

230. Wang SJ, Bourguignon LY. Hyaluronan and the interaction between CD44 and epidermal growth factor receptor in oncogenic signaling and chemotherapy resistance in head and neck cancer. Arch Otolaryngol Head Neck Surg (2006) 132:771-8. doi:10.1001/archotol.132.7.771

231. Sherman LS, Rizvi TA, Karyala S, Ratner N. CD44 enhances neuregulin signaling by schwann cells. J Cell Biol (2000) 150:1071-84. doi:10.1083/jcb. 150.5.1071

232. Bourguignon LY, Zhu H, Zhou B, Diedrich F, Singleton PA, Hung MC. Hyaluronan promotes CD44v3-Vav2 interaction with Grb2-p185(HER2) and induces Rac1 and Ras signaling during ovarian tumor cell migration and growth. J Biol Chem (2001) 276:48679-92. doi:10.1074/jbc.M106759200

233. Cooper JA, Qian H. A mechanism for SRC kinase-dependent signaling by noncatalytic receptors. Biochemistry (2008) 47:5681-8. doi:10.1021/ bi8003044

234. Marhaba R, Zoller M. CD44 in cancer progression: adhesion, migration and growth regulation. J Mol Histol (2004) 35:211-31. doi:10.1023/B:HIJO. 0000032354.94213 .69

235. Ingley E. Src family kinases: regulation of their activities, levels and identification of new pathways. Biochim Biophys Acta (2008) 1784:56-65. doi:10.1016/ j.bbapap.2007.08.012

236. Orian-Rousseau V, Morrison H, Matzke A, Kastilan T, Pace G, Herrlich P, et al. Hepatocyte growth factor-induced Ras activation requires ERM proteins linked to both CD44v6 and F-actin. Mol Biol Cell (2007) 18:76-83. doi:10. 1091/mbc.E06-08-0674

237. Weber GF. Molecular mechanisms of metastasis. Cancer Lett (2008) 270:181-90. doi:10.1016/j.canlet.2008.04.030

238. Krause DS, Van Etten RA. Tyrosine kinases as targets for cancer therapy. NEngl J Med (2005) 353:172-87. doi:10.1056/NEJMra044389

239. Adamia S, Maxwell CA, Pilarski LM. Hyaluronan and hyaluronan synthases: potential therapeutic targets in cancer. Curr Drug Targets Cardiovasc Haematol Disord (2005) 5:3-14. doi:10.2174/1568006053005056

240. Miletti-Gonzalez KE, Chen S, Muthukumaran N, Saglimbeni GN, Wu X, Yang J, et al. The CD44 receptor interacts with P-glycoprotein to promote cell migration and invasion in cancer. Cancer Res (2005) 65:6660-7. doi:10.1158/ 0008-5472.CAN-04-3478

241. Misra S, Ghatak S, Zoltan-Jones A, Toole BP. Regulation of multidrug resistance in cancer cells by hyaluronan. J Biol Chem (2003) 278:25285-8. doi:10. 1074/jbc.C300173200

242. Liu CM, Chang $\mathrm{CH}$, Yu CH, Hsu CC, Huang LL. Hyaluronan substratum induces multidrug resistance in human mesenchymal stem cells via CD44 signaling. Cell Tissue Res (2009) 336:465-75. doi:10.1007/ s00441-009-0780-3

243. Bourguignon LY, Spevak CC, Wong G, Xia W, Gilad E. Hyaluronan-CD44 interaction with protein kinase $\mathrm{C}$ (epsilon) promotes oncogenic signaling by 
the stem cell marker Nanog and the Production of microRNA-21, leading to down-regulation of the tumor suppressor protein PDCD4, anti-apoptosis, and chemotherapy resistance in breast tumor cells. J Biol Chem (2009) 284:26533-46. doi:10.1074/jbc.M109.027466

244. Hao J, Chen H, Madigan MC, Cozzi PJ, Beretov J, Xiao W, et al. Coexpression of CD147 (EMMPRIN), CD44v3-10, MDR1 and monocarboxylate transporters is associated with prostate cancer drug resistance and progression. Br J Cancer (2010) 103:1008-18. doi:10.1038/sj.bjc.6605839

245. Huang Q, Gumireddy K, Schrier M, Le Sage C, Nagel R, Nair S, et al. The microRNAs miR-373 and miR-520c promote tumour invasion and metastasis. Nat Cell Biol (2008) 10:202-10. doi:10.1038/ncb1681

246. Cheng C, Yaffe MB, Sharp PA. A positive feedback loop couples Ras activation and CD44 alternative splicing. Genes Dev (2006) 20:1715-20. doi:10.1101/gad. 1430906

247. Orian-Rousseau V, Chen L, Sleeman JP, Herrlich P, Ponta H. CD44 is required for two consecutive steps in HGF/c-Met signaling. Genes Dev (2002) 16:3074-86. doi:10.1101/gad.242602

248. Ghatak S, Hascall VC, Berger FG, Penas MM, Davis C, Jabari E, et al. Tissuespecific shRNA delivery: a novel approach for gene therapy in cancer. Connect Tissue Res (2008) 49:265-9. doi:10.1080/03008200802147845

249. Liu CM, Yu CH, Chang CH, Hsu CC, Huang LL. Hyaluronan substratum holds mesenchymal stem cells in slow-cycling mode by prolonging G1 phase. Cell Tissue Res (2008) 334:435-43. doi:10.1007/s00441-008-0699-0

250. Fehon RG, McClatchey AI, Bretscher A. Organizing the cell cortex: the role of ERM proteins. Nat Rev Mol Cell Biol (2010) 11:276-87. doi:10.1038/ nrm2866

251. Lokeshwar VB, Fregien N, Bourguignon LY. Ankyrin-binding domain of CD44(GP85) is required for the expression of hyaluronic acid-mediated adhesion function. J Cell Biol (1994) 126:1099-109. doi:10.1083/jcb.126.4.1099

252. Mori T, Kitano K, Terawaki S, Maesaki R, Fukami Y, Hakoshima T. Structural basis for CD44 recognition by ERM proteins. J Biol Chem (2008) 283:29602-12. doi:10.1074/jbc.M803606200

253. Stamenkovic I, Yu Q. Merlin, a "magic" linker between extracellular cues and intracellular signaling pathways that regulate cell motility, proliferation, and survival. Curr Protein Pept Sci (2010) 11:471-84. doi:10.2174/ 138920310791824011

254. Bai Y, Liu YJ, Wang H, Xu Y, Stamenkovic I, Yu Q. Inhibition of the hyaluronan-CD44 interaction by merlin contributes to the tumorsuppressor activity of merlin. Oncogene (2007) 26:836-50. doi:10.1038/sj.onc. 1209849

255. Maxwell CA, McCarthy J, Turley E. Cell-surface and mitotic-spindle RHAMM: moonlighting or dual oncogenic functions? J Cell Sci (2008) 121:925-32. doi: $10.1242 /$ jcs. 022038

256. Hall CL, Yang B, Yang X, Zhang S, Turley M, Samuel S, et al. Overexpression of the hyaluronan receptor RHAMM is transforming and is also required for H-ras transformation. Cell (1995) 82:19-28. doi:10.1016/0092-8674(95) 90048-9

257. Turley EA, Austen L, Moore D, Hoare K. Ras-transformed cells express both CD44 and RHAMM hyaluronan receptors: only RHAMM is essential for hyaluronan-promoted locomotion. Exp Cell Res (1993) 207:277-82. doi:10. 1006/excr.1993.1194

258. Entwistle J, Zhang S, Yang B, Wong C, Li Q, Hall CL, et al. Characterization of the murine gene encoding the hyaluronan receptor RHAMM. Gene (1995) 163:233-8. doi:10.1016/0378-1119(95)00398-P

259. Tolg C, Hamilton SR, Nakrieko KA, Kooshesh F, Walton P, McCarthy JB, et al. Rhamm-/- fibroblasts are defective in CD44-mediated ERK1,2 motogenic signaling, leading to defective skin wound repair. J Cell Biol (2006) 175(6):1017-28. doi:10.1083/jcb.200511027

260. Klewes L, Turley EA, Prehm P. The hyaluronate synthase from a eukaryotic cell line. Biochem J (1993) 290(Pt 3):791-5.

261. Park D, Kim Y, Kim H, Kim K, Lee YS, Choe J, et al. Hyaluronic acid promotes angiogenesis by inducing RHAMM-TGFbeta receptor interaction via CD44PKCdelta. Mol Cells (2012) 33:563-74. doi:10.1007/s10059-012-2294-1

262. Nikitovic D, Kouvidi K, Karamanos NK, Tzanakakis GN. The roles of hyaluronan/RHAMM/CD44 and their respective interactions along the insidious pathways of fibrosarcoma progression. Biomed Res Int (2013) 2013:929531. doi:10.1155/2013/929531

263. Hatano H, Shigeishi H, Kudo Y, Higashikawa K, Tobiume K, Takata T, et al. RHAMM/ERK interaction induces proliferative activities of cementifying fibroma cells through a mechanism based on the CD44-EGFR. Lab Invest (2011) 91:379-91. doi:10.1038/labinvest.2010.176

264. Du YC, Chou CK, Klimstra DS, Varmus H. Receptor for hyaluronan-mediated motility isoform B promotes liver metastasis in a mouse model of multistep tumorigenesis and a tail vein assay for metastasis. Proc Natl Acad Sci U S A (2011) 108:16753-8. doi:10.1073/pnas.1114022108

265. Savani RC, Cao G, Pooler PM, Zaman A, Zhou Z, DeLisser HM. Differential involvement of the hyaluronan (HA) receptors $\mathrm{CD} 44$ and receptor for HAmediated motility in endothelial cell function and angiogenesis. J Biol Chem (2001) 276:36770-8. doi:10.1074/jbc.M102273200

266. Manzanares D, Monzon ME, Savani RC, Salathe M. Apical oxidative hyaluronan degradation stimulates airway ciliary beating via RHAMM and RON. Am J Respir Cell Mol Biol (2007) 37:160-8. doi:10.1165/rcmb. 2006-0413OC

267. Jiang J, Casalegno-Garduno R, Chen H, Schmitt A, Schmitt M, Maxwell CA. Multifunctional proteins bridge mitosis with motility and cancer with inflammation and arthritis. Scientific WorldJournal (2010) 10:1244-57. doi:10. 1100/tsw.2010.141

268. Assmann V, Jenkinson D, Marshall JF, Hart IR. The intracellular hyaluronan receptor RHAMM/IHABP interacts with microtubules and actin filaments. J Cell Sci (1999) 112:3943-54.

269. Hamilton SR, Fard SF, Paiwand FF, Tolg C, Veiseh M, Wang C, et al. The hyaluronan receptors CD44 and Rhamm (CD168) form complexes with ERK1,2 that sustain high basal motility in breast cancer cells. J Biol Chem (2007) 282:16667-80. doi:10.1074/jbc.M702078200

270. Mani SA, Guo W, Liao MJ, Eaton EN, Ayyanan A, Zhou AY, et al. The epithelial-mesenchymal transition generates cells with properties of stem cells. Cell (2008) 133:704-15. doi:10.1016/j.cell.2008.03.027

271. Hall CL, Lange LA, Prober DA, Zhang S, Turley EA. pp60(c-src) is required for cell locomotion regulated by the hyaluronanreceptor RHAMM. Oncogene (1996) 13:2213-24.

272. Joukov V, Groen AC, Prokhorova T, Gerson R, White E, Rodriguez A, et al. The BRCA1/BARD1 heterodimer modulates ran-dependent mitotic spindle assembly. Cell (2006) 127:539-52. doi:10.1016/j.cell.2006.08.053

273. Pujana MA, Han JD, Starita LM, Stevens KN, Tewari M, Ahn JS, et al. Network modeling links breast cancer susceptibility and centrosome dysfunction. Nat Genet (2007) 39:1338-49. doi:10.1038/ng.2007.2

274. Mori D, Yamada M, Mimori-Kiyosue Y, Shirai Y, Suzuki A, Ohno S, et al. An essential role of the aPKC-Aurora A-NDEL1 pathway in neurite elongation by modulation of microtubule dynamics. Nat Cell Biol (2009) 11:1057-68. doi:10.1038/ncb1919

275. Bromberg KD, Mảayan A, Neves SR, Iyengar R. Design logic of a cannabinoid receptor signaling network that triggers neurite outgrowth. Science (2008) 320:903-9. doi:10.1126/science.1152662

276. Nagy JI, Hacking J, Frankenstein UN, Turley EA. Requirement of the hyaluronan receptor RHAMM in neurite extension and motility as demonstrated in primary neurons and neuronal cell lines. J Neurosci (1995) 15:241-52.

277. Thorne RF, Legg JW, Isacke CM. The role of the CD44 transmembrane and cytoplasmic domains in co-ordinating adhesive and signalling events. J Cell Sci (2004) 117:373-80. doi:10.1242/jcs.00954

278. Dunn S, Kolomytkin OV, Waddell DD, Marino AA. Hyaluronan-binding receptors: possible involvement in osteoarthritis. Mod Rheumatol (2009) 19:151-5. doi:10.1007/s10165-008-0136-y

279. Greiner J, Bullinger L, Guinn BA, Dohner H, Schmitt M. Leukemiaassociated antigens are critical for the proliferation of acute myeloid leukemia cells. Clin Cancer Res (2008) 14:7161-6. doi:10.1158/1078-0432. CCR-08-1102

280. Mantripragada KK, Spurlock G, Kluwe L, Chuzhanova N, Ferner RE, Frayling IM, et al. High-resolution DNA copy number profiling of malignant peripheral nerve sheath tumors using targeted microarray-based comparative genomic hybridization. Clin Cancer Res (2008) 14:1015-24. doi:10.1158/1078-0432. CCR-07-1305

281. Sohr S, Engeland K. RHAMM is differentially expressed in the cell cycle and downregulated by the tumor suppressor p53. Cell Cycle (2008) 7:3448-60. doi:10.4161/cc.7.21.7014

282. Pilarski LM, Pruski E, Wizniak J, Paine D, Seeberger K, Mant MJ, et al. Potential role for hyaluronan and the hyaluronan receptor RHAMM in mobilization and trafficking of hematopoietic progenitor cells. Blood (1999) 93:2918-27. 
283. Li H, Guo L, Li JW, Liu N, Qi R, Liu J. Expression of hyaluronan receptors CD44 and RHAMM in stomach cancers: relevance with tumor progression. Int J Oncol (2000) 17:927-32.

284. Liu S, Jin MN, Quan YS, Kamiyama F, Katsumi H, Sakane T, et al. The development and characteristics of novel microneedle arrays fabricated from hyaluronic acid, and their application in the transdermal delivery of insulin. J Control Release (2012) 161:933-41. doi:10.1016/j.jconrel.2012.05. 030

285. Park JH, Allen MG, Prausnitz MR. Biodegradable polymer microneedles: fabrication, mechanics and transdermal drug delivery. J Control Release (2005) 104:51-66. doi:10.1016/j.jconrel.2005.02.002

286. Lee JW, Park JH, Prausnitz MR. Dissolving microneedles for transdermal drug delivery. Biomaterials (2008) 29:2113-24. doi:10.1016/j.biomaterials. 2007.12.048

287. Sullivan SP, Koutsonanos DG, Del Pilar Martin M, Lee JW, Zarnitsyn V, Choi $\mathrm{SO}$, et al. Dissolving polymer microneedle patches for influenza vaccination. Nat Med (2010) 16:915-20. doi:10.1038/nm.2182

288. Matsuo K, Hirobe S, Yokota Y, Ayabe Y, Seto M, Quan YS, et al. Transcutaneous immunization using a dissolving microneedle array protects against tetanus, diphtheria, malaria, and influenza. J Control Release (2012) 160:495-501. doi:10.1016/j.jconrel.2012.04.001

289. Migliore A, Granata M. Intra-articular use of hyaluronic acid in the treatment of osteoarthritis. Clin Interv Aging (2008) 3:365-9.

290. Migliore A, Tormenta S, Massafra U, Bizzi E, Iannessi F, Alimonti A, et al. Intra-articular administration of hylan G-F 20 in patients with symptomatic hip osteoarthritis: tolerability and effectiveness in a large cohort study in clinical practice. Curr Med Res Opin (2008) 24:1309-16. doi:10.1185/ $030079908 X 291930$

291. Balazs EA. Hyaluronan as an ophthalmic viscoelastic device. Curr Pharm Biotechnol (2008) 9:236-8. doi:10.2174/138920108785161596

292. Fedok FG. Advances in minimally invasive facial rejuvenation. Curr Opin Otolaryngol Head Neck Surg (2008) 16:359-68. doi:10.1097/MOO. 0b013e3283031c7d

293. Savani RC, Hou G, Liu P, Wang C, Simons E, Grimm PC, et al. A role for hyaluronan in macrophage accumulation and collagen deposition after bleomycin-induced lung injury. Am J Respir Cell Mol Biol (2000) 23:475-84. doi:10.1165/ajrcmb.23.4.3944

294. Savani RC, Khalil N, Turley EA. Hyaluronan receptor antagonists alter skin inflammation and fibrosis following injury. Proc West Pharmacol Soc (1995) 38:131-6.

295. Turley EA, Naor D. RHAMM and CD44 peptides-analytic tools and potential drugs. Front Biosci (2012) 17:1775-94. doi:10.2741/4018

296. Johnson P, Ruffell B. CD44 and its role in inflammation and inflammatory diseases. Inflamm Allergy Drug Targets (2009) 8:208-20. doi:10.2174/ 187152809788680994

297. Wittig B, Schwarzler C, Fohr N, Gunthert U, Zoller M. Curative treatment of an experimentally induced colitis by a CD44 variant $\mathrm{V} 7$-specific antibody. $J$ Immunol (1998) 161:1069-73.

298. Schmits R, Filmus J, Gerwin N, Senaldi G, Kiefer F, Kundig T, et al. CD44 regulates hematopoietic progenitor distribution, granuloma formation, and tumorigenicity. Blood (1997) 90:2217-33.

299. Protin U, Schweighoffer T, Jochum W, Hilberg F. CD44-deficient mice develop normally with changes in subpopulations and recirculation of lymphocyte subsets. J Immunol (1999) 163:4917-23.

300. Li Y, Jiang D, Liang J, Meltzer EB, Gray A, Miura R, et al. Severe lung fibrosis requires an invasive fibroblast phenotype regulated by hyaluronan and CD44. J Exp Med (2011) 208:1459-71. doi:10.1084/jem.20102510

301. Zhang LS, Greyner HJ, Mummert ME, Petroll WM. Development of a hyaluronan bioconjugate for the topical treatment of melanoma. J Dermatol Sci (2009) 55:56-9. doi:10.1016/j.jdermsci.2009.02.014

302. Zaleski KJ, Kolodka T, Cywes-Bentley C, McLoughlin RM, Delaney ML, Charlton BT, et al. Hyaluronic acid binding peptides prevent experimental staphylococcal wound infection. Antimicrob Agents Chemother (2006) 50:3856-60. doi:10.1128/AAC.00082-06

303. Lee JC, Greenwich JL, Zhanel GG, Han X, Cumming A, Saward L, et al. Modulation of the local neutrophil response by a novel hyaluronic acid-binding peptide reduces bacterial burden during staphylococcal wound infection. Infect Immun (2010) 78:4176-86. doi:10.1128/IAI. 01364-09
304. Mummert ME, Mohamadzadeh M, Mummert DI, Mizumoto N, Takashima A. Development of a peptide inhibitor of hyaluronan-mediated leukocyte trafficking. J Exp Med (2000) 192:769-79. doi:10.1084/jem.192.6.769

305. Guan H, Nagarkatti PS, Nagarkatti M. Blockade of hyaluronan inhibits IL2-induced vascular leak syndrome and maintains effectiveness of IL-2 treatment for metastatic melanoma. J Immunol (2007) 179:3715-23. doi:10.4049/ jimmunol.179.6.3715

306. Savinov AY, Strongin AY. Defining the roles of T cell membrane proteinase and CD44 in type 1 diabetes. IUBMB Life (2007) 59:6-13. doi:10.1080/ 15216540601187795

307. Garin T, Rubinstein A, Grigoriadis N, Nedvetzki S, Abramsky O, MizrachiKoll R, et al. CD44 variant DNA vaccination with virtual lymph node ameliorates experimental autoimmune encephalomyelitis through the induction of apoptosis. J Neurol Sci (2007) 258:17-26. doi:10.1016/j.jns.2007.01.079

308. Lovvorn HN III, Cass DL, Sylvester KG, Yang EY, Crombleholme TM, Adzick NS, et al. Hyaluronan receptor expression increases in fetal excisional skin wounds and correlates with fibroplasia. J Pediatr Surg (1998) 33:1062-9. doi:10.1016/S0022-3468(98)90532-2

309. Svee K, White J, Vaillant P, Jessurun J, Roongta U, Krumwiede M, et al. Acute lung injury fibroblast migration and invasion of a fibrin matrix is mediated by CD44. J Clin Invest (1996) 98:1713-27. doi:10.1172/JCI118970

310. Lokeshwar VB, Estrella V, Lopez L, Kramer M, Gomez P, Soloway MS, et al. HYAL1-v1, an alternatively spliced variant of HYAL1 hyaluronidase: a negative regulator of bladder cancer. Cancer Res (2006) 66:11219-27. doi:10.1158/ 0008-5472.CAN-06-1121

311. Grandoch M, Hoffmann J, Rock K, Wenzel F, Oberhuber A, Schelzig H, et al. Novel effects of adenosine receptors on pericellular hyaluronan matrix: implications for human smooth muscle cell phenotype and interactions with monocytes during atherosclerosis. Basic Res Cardiol (2013) 108:340. doi:10. 1007/s00395-013-0340-6

312. St Croix B, Rak JW, Kapitain S, Sheehan C, Graham CH, Kerbel RS. Reversal by hyaluronidase of adhesion-dependent multicellular drug resistance in mammary carcinoma cells. J Natl Cancer Inst (1996) 88:1285-96. doi:10.1093/ jnci/88.18.1285

313. St Croix B, Man S, Kerbel RS. Reversal of intrinsic and acquired forms of drug resistance by hyaluronidase treatment of solid tumors. Cancer Lett (1998) 131:35-44. doi:10.1016/S0304-3835(98)00199-2

314. Luo Y, Ziebell MR, Prestwich GD. A hyaluronic acid-taxol antitumor bioconjugate targeted to cancer cells. Biomacromolecules (2000) 1:208-18. doi:10. $1021 / \mathrm{bm} 000283 \mathrm{n}$

315. Rosato A, Banzato A, De Luca G, Renier D, Bettella F, Pagano C, et al. HYTAD1-p20: a new paclitaxel-hyaluronic acid hydrosoluble bioconjugate for treatment of superficial bladder cancer. Urol Oncol (2006) 24:207-15. doi:10.1016/j.urolonc.2005.08.020

316. Luo Y, Prestwich GD. Synthesis and selective cytotoxicity of a hyaluronic acid-antitumor bioconjugate. Bioconjug Chem (1999) 10:755-63. doi:10.1021/ bc9900338

317. Luo Y, Kirker KR, Prestwich GD. Cross-linked hyaluronic acid hydrogel films: new biomaterials for drug delivery. J Control Release (2000) 69:169-84. doi:10. 1016/S0168-3659(00)00300-X

318. Serafino A, Zonfrillo M, Andreola F, Psaila R, Mercuri L, Moroni N, et al. CD44-targeting for antitumor drug delivery: a new SN-38-hyaluronan bioconjugate for locoregional treatment of peritoneal carcinomatosis. Curr Cancer Drug Targets (2011) 11:572-85. doi:10.2174/156800911795655976

319. Bassi PF, Volpe A, D’Agostino D, Palermo G, Renier D, Franchini S, et al. Paclitaxel-hyaluronic acid for intravesical therapy of bacillus Calmette-Guerin refractory carcinoma in situ of the bladder: results of a phase I study. J Urol (2011) 185:445-9. doi:10.1016/j.juro.2010.09.073

320. Montagner IM, Banzato A, Zuccolotto G, Renier D, Campisi M, Bassi P, et al. Paclitaxel-hyaluronan hydrosoluble bioconjugate: mechanism of action in human bladder cancer cell lines. Urol Oncol (2013) 31:1261-9. doi:10.1016/ j.urolonc.2012.01.005

321. Brown TJ. The development of hyaluronan as a drug transporter and excipient for chemotherapeutic drugs. Curr Pharm Biotechnol (2008) 9:253-60. doi:10. 2174/138920108785161514

322. Rosenthal MA, Gibbs P, Brown TJ, Wong S, Uren S, Ellis A, et al. Phase I and pharmacokinetic evaluation of intravenous hyaluronic acid in combination with doxorubicin or 5-fluorouracil. Chemotherapy (2005) 51:132-41. doi:10. $1159 / 000085621$ 
323. Gibbs P, Brown TJ, Ng R, Jennens R, Cinc E, Pho M, et al. A pilot human evaluation of a formulation of irinotecan and hyaluronic acid in 5fluorouracil-refractory metastatic colorectal cancer patients. Chemotherapy (2009) 55:49-59. doi:10.1159/000180339

324. Varghese OP, Sun W, Hilborn J, Ossipov DA. In situ cross-linkable high molecular weight hyaluronan-bisphosphonate conjugate for localized delivery and cell-specific targeting: a hydrogel linked prodrug approach. J Am Chem Soc (2009) 131:8781-3. doi:10.1021/ja902857b

325. Meo CD, Panza L, Capitani D, Mannina L, Banzato A, Rondina M, et al. Hyaluronan as carrier of carboranes for tumor targeting in boron neutron capture therapy. Biomacromolecules (2007) 8:552-9. doi:10.1021/ bm0607426

326. Di Meo C, Panza L, Campo F, Capitani D, Mannina L, Banzato A, et al. Novel types of carborane-carrier hyaluronan derivatives via "click chemistry". Macromol Biosci (2008) 8:670-81. doi:10.1002/mabi.200700304

327. Jain A, Jain SK. In vitro and cell uptake studies for targeting of ligand anchored nanoparticles for colon tumors. Eur J Pharm Sci (2008) 35:404-16. doi:10. 1016/j.ejps.2008.08.008

328. Jain A, Jain SK, Ganesh N, Barve J, Beg AM. Design and development of ligand-appended polysaccharidic nanoparticles for the delivery of oxaliplatin in colorectal cancer. Nanomedicine (2010) 6:179-90. doi:10.1016/j.nano.2009. 03.002

329. Bachar G, Cohen K, Hod R, Feinmesser R, Mizrachi A, Shpitzer T, et al. Hyaluronan-grafted particle clusters loaded with mitomycin $\mathrm{C}$ as selective nanovectors for primary head and neck cancers. Biomaterials (2011) 32:4840-8. doi:10.1016/j.biomaterials.2011.03.040

330. Peer D, Margalit R. Loading mitomycin C inside long circulating hyaluronan targeted nano-liposomes increases its antitumor activity in three mice tumor models. Int J Cancer (2004) 108:780-9. doi:10.1002/ijc.11615

331. Peer D, Margalit R. Tumor-targeted hyaluronan nanoliposomes increase the antitumor activity of liposomal doxorubicin in syngeneic and human xenograft mouse tumor models. Neoplasia (2004) 6:343-53. doi:10.1593/neo. 03460

332. Surace C, Arpicco S, Dufay-Wojcicki A, Marsaud V, Bouclier C, Clay D, et al. Lipoplexes targeting the CD44 hyaluronic acid receptor for efficient transfection of breast cancer cells. Mol Pharm (2009) 6:1062-73. doi:10.1021/ mp800215d

333. Eliaz RE, Szoka FC Jr. Liposome-encapsulated doxorubicin targeted to CD44: a strategy to kill CD44-overexpressing tumor cells. Cancer Res (2001) 61:2592-601.

334. Ruhela D, Riviere K, Szoka FC Jr. Efficient synthesis of an aldehyde functionalized hyaluronic acid and its application in the preparation of hyaluronan-lipid conjugates. Bioconjug Chem (2006) 17:1360-3. doi:10.1021/bc0600721

335. Dufay Wojcicki A, Hillaireau H, Nascimento TL, Arpicco S, Taverna M, Ribes $\mathrm{S}$, et al. Hyaluronic acid-bearing lipoplexes: physico-chemical characterization and in vitro targeting of the CD44 receptor. J Control Release (2012) 162:545-52. doi:10.1016/j.jconrel.2012.07.015

336. Liu Y, Sun J, Cao W, Yang J, Lian H, Li X, et al. Dual targeting folate-conjugated hyaluronic acid polymeric micelles for paclitaxel delivery. Int J Pharm (2011) 421:160-9. doi:10.1016/j.ijpharm.2011.09.006

337. Qiu L, Li Z, Qiao M, Long M, Wang M, Zhang X, et al. Self-assembled pHresponsive hyaluronic acid-g-poly(l-histidine) copolymer micelles for targeted intracellular delivery of doxorubicin. Acta Biomater (2014) 10:2024-35. doi:10. 1016/j.actbio.2013.12.025

338. Zhang Y, Zhang H, Wang X, Wang J, Zhang X, Zhang Q. The eradication of breast cancer and cancer stem cells using octreotide modified paclitaxel active targeting micelles and salinomycin passive targeting micelles. Biomaterials (2012) 33:679-91. doi:10.1016/j.biomaterials.2011.09.072

339. Akima $\mathrm{K}$, Ito $\mathrm{H}$, Iwata $\mathrm{Y}$, Matsuo $\mathrm{K}$, Watari N, Yanagi M, et al. Evaluation of antitumor activities of hyaluronate binding antitumor drugs: synthesis, characterization and antitumor activity. J Drug Target (1996) 4:1-8. doi:10. 3109/10611869609046255

340. Lee H, Mok H, Lee S, Oh YK, Park TG. Target-specific intracellular delivery of siRNA using degradable hyaluronic acid nanogels. J Control Release (2007) 119:245-52. doi:10.1016/j.jconrel.2007.02.011

341. Pellegrino T, Kudera S, Liedl T, Munoz Javier A, Manna L, Parak WJ. On the development of colloidal nanoparticles towards multifunctional structures and their possible use for biological applications. Small (2005) 1:48-63. doi:10. 1002/smll.200400071
342. Tenne R. Inorganic nanotubes and fullerene-like nanoparticles. Nat Nanotechnol (2006) 1:103-11. doi:10.1038/nnano.2006.62

343. Baker SN, Baker GA. Luminescent carbon nanodots: emergent nanolights. Angew Chem Int Ed Engl (2011) 49:6726-44. doi:10.1002/anie.200906623

344. Geim AK. Graphene: status and prospects. Science (2009) 324:1530-4. doi:10. $1126 /$ science. 1158877

345. Lee MY, Yang JA, Jung HS, Beack S, Choi JE, Hur W, et al. Hyaluronic acidgold nanoparticle/interferon alpha complex for targeted treatment of hepatitis C virus infection. ACS Nano (2012) 6:9522-31. doi:10.1021/nn302538y

346. Kumar A, Sahoo B, Montpetit A, Behera S, Lockey RF, Mohapatra SS. Development of hyaluronic acid-Fe2O3 hybrid magnetic nanoparticles for targeted delivery of peptides. Nanomedicine (2007) 3:132-7. doi:10.1016/j.nano.2007. 03.001

347. Lu J, Liong M, Li Z, Zink JI, Tamanoi F. Biocompatibility, biodistribution, and drug-delivery efficiency of mesoporous silica nanoparticles for cancer therapy in animals. Small (2010) 6:1794-805. doi:10.1002/smll.201000538

348. Cho HJ, Yoon HY, Koo H, Ko SH, Shim JS, Lee JH, et al. Self-assembled nanoparticles based on hyaluronic acid-ceramide (HA-CE) and Pluronic(R) for tumor-targeted delivery of docetaxel. Biomaterials (2011) 32:7181-90. doi:10.1016/j.biomaterials.2011.06.028

349. Harris EN, Kyosseva SV, Weigel JA, Weigel PH. Expression, processing, and glycosaminoglycan binding activity of the recombinant human 315$\mathrm{kDa}$ hyaluronic acid receptor for endocytosis (HARE). J Biol Chem (2007) 282:2785-97. doi:10.1074/jbc.M607787200

350. Ruoslahti E, Bhatia SN, Sailor MJ. Targeting of drugs and nanoparticles to tumors. J Cell Biol (2010) 188:759-68. doi:10.1083/jcb.200910104

351. Allouche M, Charrad RS, Bettaieb A, Greenland C, Grignon C, Smadja-Joffe F. Ligation of the CD44 adhesion molecule inhibits drug-induced apoptosis in human myeloid leukemia cells. Blood (2000) 96:1187-90.

352. Bates RC, Edwards NS, Burns GF, Fisher DE. A CD44 survival pathway triggers chemoresistance via lyn kinase and phosphoinositide 3-kinase/Akt in colon carcinoma cells. Cancer Res (2001) 61:5275-83.

353. Yu Q, Toole BP, Stamenkovic I. Induction of apoptosis of metastatic mammary carcinoma cells in vivo by disruption of tumor cell surface CD44 function. $J$ Exp Med (1997) 186:1985-96. doi:10.1084/jem.186.12.1985

354. Urakawa H, Nishida Y, Knudson W, Knudson CB, Arai E, Kozawa E, et al. Therapeutic potential of hyaluronan oligosaccharides for bone metastasis of breast cancer. J Orthop Res (2012) 30:662-72. doi:10.1002/jor.21557

355. Fuchs K, Hippe A, Schmaus A, Homey B, Sleeman JP, Orian-Rousseau V. Opposing effects of high- and low-molecular weight hyaluronan on CXCL12induced CXCR4 signaling depend on CD44. Cell Death Dis (2013) 4:e819. doi:10.1038/cddis.2013.364

356. Morrison H, Sherman LS, Legg J, Banine F, Isacke C, Haipek CA, et al. The NF2 tumor suppressor gene product, merlin, mediates contact inhibition of growth through interactions with CD44. Genes Dev (2001) 15:968-80. doi:10. 1101/gad.189601

357. Horton MR, Burdick MD, Strieter RM, Bao C, Noble PW. Regulation of hyaluronan-induced chemokine gene expression by IL-10 and IFN-gamma in mouse macrophages. J Immunol (1998) 160:3023-30.

358. Peterson RM, Yu Q, Stamenkovic I, Toole BP. Perturbation of hyaluronan interactions by soluble CD44 inhibits growth of murine mammary carcinoma cells in ascites. Am J Pathol (2000) 156:2159-67. doi:10.1016/S0002-9440(10) 65086-9

359. Ahrens T, Sleeman JP, Schempp CM, Howells N, Hofmann M, Ponta H, et al. Soluble CD44 inhibits melanoma tumor growth by blocking cell surface CD44 binding to hyaluronic acid. Oncogene (2001) 20:3399-408. doi:10.1038/sj.onc. 1204435

360. Xu XM, Chen Y, Chen J, Yang S, Gao F, Underhill CB, et al. A peptide with three hyaluronan binding motifs inhibits tumor growth and induces apoptosis. Cancer Res (2003) 63:5685-90.

361. Song G, Liao X, Zhou L, Wu L, Feng Y, Han ZC. HI44a, an anti-CD44 monoclonal antibody, induces differentiation and apoptosis of human acute myeloid leukemia cells. Leuk Res (2004) 28:1089-96. doi:10.1016/j.leukres.2004.02.005

362. Colnot DR, Wilhelm AJ, Cloos J, Roos JC, de Bree R, Quak JJ, et al. Evaluation of limited blood sampling in a preceding $99 \mathrm{mTc}$-labeled diagnostic study to predict the pharmacokinetics and myelotoxicity of 186Re-cMAb U36 radioimmunotherapy. J Nucl Med (2001) 42:1364-7.

363. de Bree R, Roos JC, Quak JJ, den Hollander W, Snow GB, van Dongen GA. Radioimmunoscintigraphy and biodistribution of technetium-99m-labeled 
monoclonal antibody U36 in patients with head and neck cancer. Clin Cancer Res (1995) 1:591-8.

364. de Bree R, Roos JC, Quak JJ, den Hollander W, Wilhelm AJ, van Lingen A, et al. Biodistribution of radiolabeled monoclonal antibody E48 IgG and F(ab')2 in patients with head and neck cancer. Clin Cancer Res (1995) 1:277-86.

365. Borjesson PK, Postema EJ, Roos JC, Colnot DR, Marres HA, van Schie MH, et al. Phase I therapy study with (186)Re-labeled humanized monoclonal antibody BIWA 4 (bivatuzumab) in patients with head and neck squamous cell carcinoma. Clin Cancer Res (2003) 9:3961S-72S.

366. Colnot DR, Roos JC, de Bree R, Wilhelm AJ, Kummer JA, Hanft G, et al. Safety, biodistribution, pharmacokinetics, and immunogenicity of $99 \mathrm{mTc}$-labeled humanized monoclonal antibody BIWA 4 (bivatuzumab) in patients with squamous cell carcinoma of the head and neck. Cancer Immunol Immunother (2003) 52:576-82. doi:10.1007/s00262-003-0396-5

367. Heider KH, Sproll M, Susani S, Patzelt E, Beaumier P, Ostermann E, et al. Characterization of a high-affinity monoclonal antibody specific for CD44v6 as candidate for immunotherapy of squamous cell carcinomas. Cancer Immunol Immunother (1996) 43:245-53. doi:10.1007/s002620050329

368. Schrijvers AH, Quak JJ, Uyterlinde AM, van Walsum M, Meijer CJ, Snow $\mathrm{GB}$, et al. MAb U36, a novel monoclonal antibody successful in immunotargeting of squamous cell carcinoma of the head and neck. Cancer Res (1993) 53:4383-90.

369. Tijink BM, Buter J, de Bree R, Giaccone G, Lang MS, Staab A, et al. A phase I dose escalation study with anti-CD44v6 bivatuzumab mertansine in patients with incurable squamous cell carcinoma of the head and neck or esophagus. Clin Cancer Res (2006) 12:6064-72. doi:10.1158/1078-0432.CCR-06-0910

370. Sauter A, Kloft C, Gronau S, Bogeschdorfer F, Erhardt T, Golze W, et al. Pharmacokinetics, immunogenicity and safety of bivatuzumab mertansine, a novel CD44v6-targeting immunoconjugate, in patients with squamous cell carcinoma of the head and neck. Int J Oncol (2007) 30:927-35.

371. Jin L, Hope KJ, Zhai Q, Smadja-Joffe F, Dick JE. Targeting of CD44 eradicates human acute myeloid leukemic stem cells. Nat Med (2006) 12:1167-74. doi:10. $1038 / \mathrm{nm} 1483$

372. Matzke A, Herrlich P, Ponta H, Orian-Rousseau V. A five-amino-acid peptide blocks Met- and Ron-dependent cell migration. Cancer Res (2005) 65:6105-10. doi:10.1158/0008-5472.CAN-05-0207

373. Peck D, Isacke CM. Hyaluronan-dependent cell migration can be blocked by a CD44 cytoplasmic domain peptide containing a phosphoserine at position 325. J Cell Sci (1998) 111:1595-601.

374. Desai B, Ma T, Zhu J, Chellaiah MA. Characterization of the expression of variant and standard CD44 in prostate cancer cells: identification of the possible molecular mechanism of CD44/MMP9 complex formation on the cell surface. J Cell Biochem (2009) 108:272-84. doi:10.1002/jcb.22248

375. Piotrowicz RS, Damaj BB, Hachicha M, Incardona F, Howell SB, Finlayson M. A6 peptide activates $\mathrm{CD} 44$ adhesive activity, induces FAK and MEK phosphorylation, and inhibits the migration and metastasis of CD44-expressing cells. Mol Cancer Ther (2011) 10:2072-82. doi:10.1158/1535-7163. MCT-11-0351

376. Boyd DD, Kim SJ, Wang H, Jones TR, Gallick GE. A urokinase-derived peptide (A6) increases survival of mice bearing orthotopically grown prostate cancer and reduces lymph node metastasis. Am J Pathol (2003) 162:619-26. doi:10. 1016/S0002-9440(10)63855-2

377. Mummert ME, Mummert DI, Ellinger L, Takashima A. Functional roles of hyaluronan in B16-F10 melanoma growth and experimental metastasis in mice. Mol Cancer Ther (2003) 2:295-300.

378. Bennett KL, Modrell B, Greenfield B, Bartolazzi A, Stamenkovic I, Peach R, et al. Regulation of CD44 binding to hyaluronan by glycosylation of variably spliced exons. J Cell Biol (1995) 131:1623-33. doi:10.1083/jcb.131.6.1623

379. van der Voort R, Manten-Horst E, Smit L, Ostermann E, van den Berg F, Pals ST. Binding of cell-surface expressed CD44 to hyaluronate is dependent on splicing and cell type. Biochem Biophys Res Commun (1995) 214:137-44. doi:10.1006/bbrc.1995.2267

380. Girish KS, Kemparaju K. The magic glue hyaluronan and its eraser hyaluronidase: a biological overview. Life Sci (2007) 80:1921-43. doi:10.1016/ j.lfs.2007.02.037

381. Stern R. Association between cancer and "acid mucopolysaccharides": an old concept comes of age, finally. Semin Cancer Biol (2008) 18:238-43. doi:10. 1016/j.semcancer.2008.03.014
382. Wang N, Tytell JD, Ingber DE. Mechanotransduction at a distance: mechanically coupling the extracellular matrix with the nucleus. Nat Rev Mol Cell Biol (2009) 10:75-82. doi:10.1038/nrm2594

383. Itano N, Kimata K. Altered hyaluronan biosynthesis in cancer progression. Semin Cancer Biol (2008) 18:268-74. doi:10.1016/j.semcancer.2008.03.006

384. Klingbeil P, Marhaba R, Jung T, Kirmse R, Ludwig T, Zoller M. D44 variant isoforms promote metastasis formation by a tumor cell-matrix cross-talk that supports adhesion and apoptosis resistance. Mol Cancer Res (2009) 7:168-79. doi:10.1158/1541-7786.MCR-08-0207

385. Todaro M, Gaggianesi M, Catalano V, Benfante A, Iovino F, Biffoni M, et al. CD44v6 is a marker of constitutive and reprogrammed cancer stem cells driving colon cancer metastasis. Cell Stem Cell (2014) 14:342-56. doi:10.1016/ j.stem.2014.01.009

386. Paul CP, Good PD, Winer I, Engelke DR. Effective expression of small interfering RNA in human cells. Nat Biotechnol (2002) 20:505-8. doi:10.1038/ nbt0502-505

387. Raper se, Chirmule N, Lee FS, Wivel NA, Bagg A, Gao GP, et al. Fatal systemic inflammatory response syndrome in a ornithine transcarbamylase deficient patient following adenoviral gene transfer. Mol Genet Metab (2003) 80:148-58. doi:10.1016/j.ymgme.2003.08.016

388. Kursa M, Walker GF, Roessler V, Ogris M, Roedl W, Kircheis R, et al. Novel shielded transferrin-polyethylene glycol-polyethylenimine/DNA complexes for systemic tumor-targeted gene transfer. Bioconjug Chem (2003) 14:222-31. doi:10.1021/bc0256087

389. Bellocq NC, Pun SH, Jensen GS, Davis ME. Transferrin-containing, cyclodextrin polymer-based particles for tumor-targeted gene delivery. Bioconjug Chem (2003) 14:1122-32. doi:10.1021/bc034125f

390. Qian ZM, Li H, Sun H, Ho K. Targeted drug delivery via the transferrin receptor-mediated endocytosis pathway. Pharmacol Rev (2002) 54:561-87. doi:10.1124/pr.54.4.561

391. Twarock S, Tammi MI, Savani RC, Fischer JW. Hyaluronan stabilizes focal adhesions, filopodia, and the proliferative phenotype in esophageal squamous carcinoma cells. J Biol Chem (2010) 285:23276-84. doi:10.1074/jbc.M109. 093146

392. Greiner J, Schmitt A, Giannopoulos K, Rojewski MT, Gotz M, Funk I, et al. High-dose RHAMM-R3 peptide vaccination for patients with acute myeloid leukemia, myelodysplastic syndrome and multiple myeloma. Haematologica (2010) 95:1191-7. doi:10.3324/haematol.2009.014704

393. Schmitt M, Schmitt A, Rojewski MT, Chen J, Giannopoulos K, Fei F, et al. RHAMM-R3 peptide vaccination in patients with acute myeloid leukemia, myelodysplastic syndrome, and multiple myeloma elicits immunologic and clinical responses. Blood (2008) 111:1357-65. doi:10.1182/blood-2007-07-099366

394. Mohan P, Castellsague J, Jiang J, Allen K, Chen H, Nemirovsky O, et al. Genomic imbalance of HMMR/RHAMM regulates the sensitivity and response of malignant peripheral nerve sheath tumour cells to aurora kinase inhibition. Oncotarget (2013) 4:80-93.

395. Tilghman J, Wu H, Sang Y, Shi X, Guerrero-Cazares H, Quinones-Hinojosa A, et al. HMMR maintains the stemness and tumorigenicity of glioblastoma stem-like cells. Cancer Res (2014) 74:3168-79. doi:10.1158/0008-5472. CAN-13-2103

396. Shi Y, Reiman T, Li W, Maxwell CA, Sen S, Pilarski L, et al. Targeting aurora kinases as therapy in multiple myeloma. Blood (2007) 109:3915-21. doi:10. 1182/blood-2006-07-037671

397. Otto T, Horn S, Brockmann M, Eilers U, Schuttrumpf L, Popov N, et al. Stabilization of $\mathrm{N}-\mathrm{Myc}$ is a critical function of aurora $\mathrm{A}$ in human neuroblastoma Cancer Cell (2009) 15:67-78. doi:10.1016/j.ccr.2008.12.005

398. Capasso M, Devoto M, Hou C, Asgharzadeh S, Glessner JT, Attiyeh EF, et al. Common variations in BARD1 influence susceptibility to high-risk neuroblastoma. Nat Genet (2009) 41:718-23. doi:10.1038/ng.374

399. Giannopoulos K, Dmoszynska A, Kowal M, Rolinski J, Gostick E, Price DA, et al. Peptide vaccination elicits leukemia-associated antigen-specific cytotoxic CD8+ T-cell responses in patients with chronic lymphocytic leukemia. Leukemia (2010) 24:798-805. doi:10.1038/leu.2010.29

400. Amano T, Kajiwara K, Yoshikawa K, Morioka J, Nomura S, Fujisawa H, et al. Antitumor effects of vaccination with dendritic cells transfected with modified receptor for hyaluronan-mediated motility mRNA in a mouse glioma model. J Neurosurg (2007) 106:638-45. doi:10.3171/jns.2007.106.4.638 
401. Cheng C, Sharp PA. Regulation of CD44 alternative splicing by SRm160 and its potential role in tumor cell invasion. Mol Cell Biol (2006) 26:362-70. doi:10. 1128/MCB.26.1.362-370.2006

Conflict of Interest Statement: The authors declare that the research was conducted in the absence of any commercial or financial relationships that could be construed as a potential conflict of interest.
Copyright (c) 2015 Misra, Hascall, Markwald and Ghatak. This is an open-access article distributed under the terms of the Creative Commons Attribution License (CC BY). The use, distribution or reproduction in other forums is permitted, provided the original author(s) or licensor are credited and that the original publication in this journal is cited, in accordance with accepted academic practice. No use, distribution or reproduction is permitted which does not comply with these terms. 